\title{
PROCEDIMENTOS PARA CONDUÇÃO DO TESTE DE FRIO VISANDO A AVALIAÇÃO DO VIGOR DE SEMENTES DE MILHO
}

\author{
ROSELI FÁTIMA CASEIRO
}

Engenheiro Agrônomo

Orientador: Prof. Dr. JULIO MARCOS FILHO

Dissertação apresentada à Escola Superior de Agricultura "Luiz de Queiroz", Universidade de São Paulo, para obtenção do título de Mestre em Agronomia, Área de Concentração: Fitotecnia.

PIRACICABA

Estado de São Paulo - Brasil

Novembro - 1999 
Dados Internacionais de Catalogação na Publicação (CIP)

DIVISĀO DE BIBLIOTECA E DOCUMENTAÇĀO - Campus "Luiz de Queiroz"/USP

\section{Caseiro, Roseli Fátima}

Procedimentos para condução do teste de frio visando a avaliação do vigor de sementes de milho / Roseli Fátima Caseiro. - - Piracicaba, 1999.

88 p. : il.

Dissertação (mestrado) - Escola Superior de Agricultura Luiz de Queiroz, 1999. Bibliografia.

1. Efeito da temperatura 2. Metodologia 3. Qualidade fisiológica 4. Resfriamento 5. Semente de milho 6. Substrato 7. Teste de frio 8 . Teste de semente 9. Teste de vigor I. Titulo

CDD 633.15 
"A vida vale por muitas coisas e, sobretudo, pela oportunidade que nos dá para buscar o aperfeiçoamento".

Kant. 
Aos meus pais Celestino e Neuza, e aos meus irmãos Hilton, Gerson e Denilson,

meus agradecimentos vão além das palavras ...

À minha família, 


\section{AGRADECIMENTOS}

Ao Professor Julio Marcos Filho, pela orientação, amizade, paciência e constante incentivo e apoio durante a realização deste trabalho.

À Professora Ana Dionísia L. C. Novembre, à Engenheira Agrônoma Helena M. C. Pescarim Chamma e ao amigo Osmar P. Beckert, pela amizade, apoio, sugestões e colaboração na execução do experimento.

Aos Professores Silvio Moure Cicero, Walter Rodrigues da Silva e Francisco Amaral Villela, pelo ensino, apoio e amizade.

À funcionária llze Helena C. G. das Neves, pela amizade, colaboração e serviços prestados durante o curso.

Aos funcionários Carlos A. Carlet, João B. Migeli, João E. Jabur Filho, (Laboratório de Análise de Sementes), Celestino A. Ferreira e Edson A. Moraes, pela ajuda prestada na condução dos experimentos.

As funcionárias Sônia I. dos Santos e Roseneide dos Santos, pelos serviços prestados na limpeza do laboratório e do Pavilhão de Tecnologia de Sementes e, também, pela amizade.

Aos funcionários da Biblioteca Central, pelo atendimento e outros serviços prestados durante o curso.

À CAPES, pela bolsa de estudos concedida. 
À Empresa Agroceres/Monsanto, pelo fornecimento das sementes utilizadas neste trabalho.

Aos Doutores Ademir Assis Henning, Francisco Carlos Krzyzanowski e José de Barrros França Neto (Embrapa-Soja), pela amizade, pelos conselhos, e pelo constante apoio e incentivo.

Aos amigos e ex-professores Ceci Castilho Custódio e Nelson B. Machado Neto, e à Eng. Agrônoma Eliane M. F. Daltro Caseiro, pelo apoio, incentivo e amizade.

Aos amigos do Curso de Pós-Graduação, Ana Lídia V. Bonato, Ana Luiza Ramos, Angélica B. Rodo, Cleiton Perleberg, Daniel Gentil, Daniel Medeiros, Edina R. Moresco, Elvis L. Vieira, Leila Martins, Marcelo H. Miguel, Maria Cristina Spinola, Mariane V. Carvalho, Maristela Panobianco, Oscar Smiderle, Patrícia Mattiazzi, Renata Maschietto, Salvador B. Torres, Sílvia R. S. de Oliveira, Thaísa G. Fonseca, e também à Eng. Agrônoma do Departamento de Fitopatologia Maria Heloisa D. Moraes, pelo auxilio e amizade, pelos bons momentos e agradável convivência.

À Escola Superior de Agricultura "Luiz de Queiroz" (USP/ESALQ) pela oportunidade de realizar o curso. 


\section{SUMÁRIO}

Página

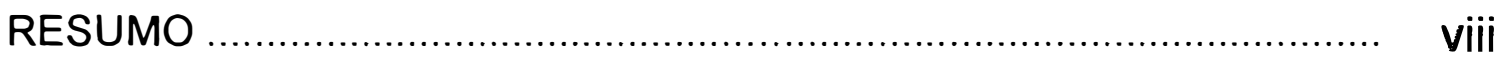

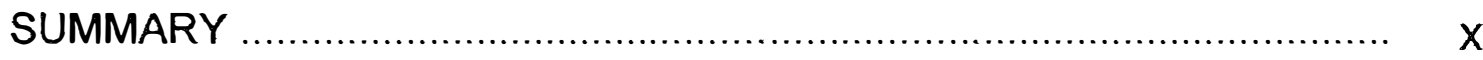

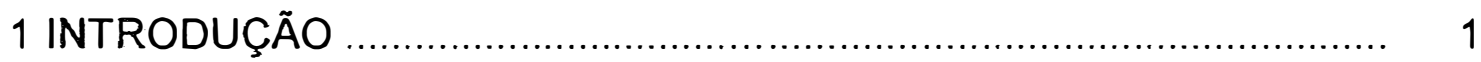

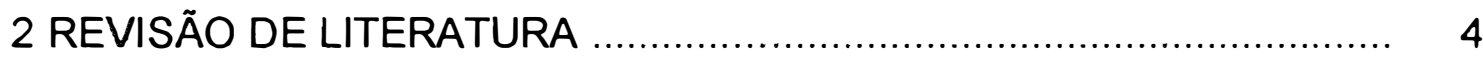

2.1 Procedimentos utilizado para a condução do teste de frio ................... 4

2.2 Comparação entre procedimentos ................................................ 11

2.3 Fatores que afetam os resultados do teste de frio ............................... 16

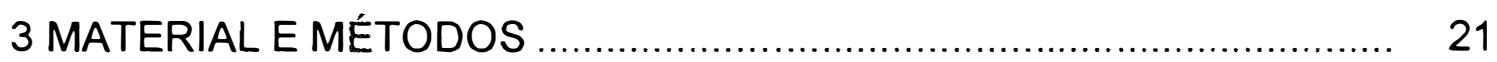

3.1 Observações preliminares sobre o teste de frio "em caixas" ............... 21

A) Estudo do pré-resfriamento do substrato ....................................... 21

B) Estudo da disposição das caixas no interior da câmara fria ............ 22

3.2 Observações preliminares sobre o teste de frio "em bandejas" ........... 24

A) Estudo do tipo e quantidade de substrato a ser utilizado ................. 24

B) Estudo da capacidade de retenção de água do substrato "terra" .... 27

C) Uso de condições controladas de temperatura, umidade relativa e luz para a germinação das sementes ........................................... 27

3.3 Comparação do teste de frio com outros métodos para a avaliação do

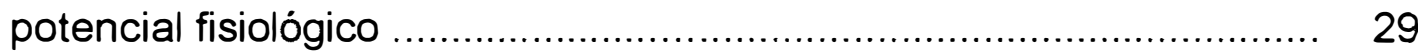

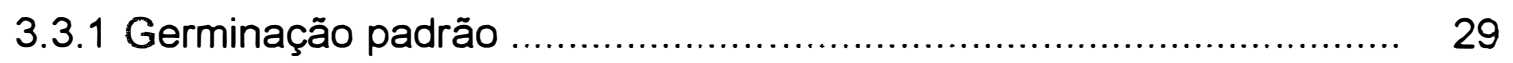

3.3.2 Teste de frio "em caixas" ........................................................ 30

3.3.2.1 Teste de frio "em caixas" empilhadas ........................................ 30

3.3.2.2 Teste de frio "em caixas" dispostas lado a lado ............................ 31

3.3.3 Teste de frio em bandejas ("Tray method") .................................... 31

3.3.3.1 Teste de frio em bandejas utilizando-se "terra" como substrato ..... 31

3.3.3.2 Teste de frio em bandejas utilizando-se "terra" e papel toalha como substrato ................................................................... 32

3.3.4 Envelhecimento acelerado ................................................... 32 
3.3.5 Grau de umidade ................................................................ 33

3.3.6 Emergência das plântulas em campo ......................................... 33

3.3.7 Procedimento estatístico .............................................................. 33

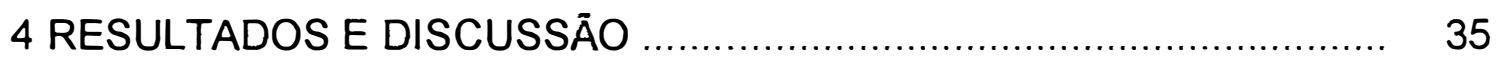

4.1 Observações preliminares sobre o teste de frio "em caixas" .............. 35

4.2 Observações preliminares sobre o teste de frio "em bandejas" ........... 45

a) Estudo do tipo e quantidade do substrato a ser utilizado ................ 45

b) Estudo da capacidade de retenção de água do substrato .............. 49

c) Uso de condições controladas de temperatura, umidade relativa e luz para germinação das sementes ........................................... 51

4.3 Comparação do teste de frio com outros métodos para avaliação do potencial fisiológico ............................................................ 54

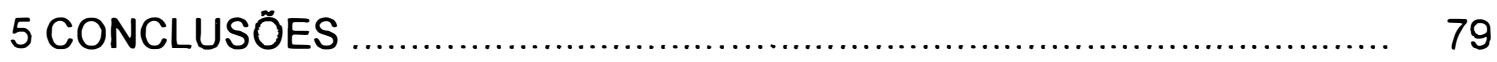

REFERÊNCIAS BIBLIOGRÁFICAS ............................................... 80 


\title{
PROCEDIMENTOS PARA CONDUÇÃO DO TESTE DE FRIO VISANDO A AVALIAÇÃO DO VIGOR DE SEMENTES DE MILHO
}

\author{
Autora: ROSEL! FÁTIMA CASEIRO \\ Orientador: Prof. Dr. JULIO MARCOS FILHO
}

\section{RESUMO}

O presente trabalho foi conduzido no Laboratório de Análise de Sementes do Departamento de Produção Vegetal da Escola Superior de Agricultura "Luiz de Queiroz" (USPIESALQ) e teve como objetivo básico estudar comparativamente duas metodologias para a condução do teste de frio, para avaliação do potencial fisiológico das sementes de milho: "terra" em caixas e em bandejas. A pesquisa constou de duas etapas. $\mathrm{Na}$ primeira, foram realizados testes preliminares para comparar vários procedimentos para o teste de frio, visando selecionar o (s) mais adequado (s) para a continuação do estudo, em uma segunda etapa. A partir das observações preliminares, que incluíram o pré-resfriamento do substrato, disposição das caixas no interior da câmara fria, tipo e quantidade do substrato, capacidade de retenção de água do substrato e condições controladas de temperatura, umidade relativa e luz para a germinação das sementes após o período de frio, foram selecionados quatro protocolos. Com relação ao teste de frio utilizando-se substrato "terra" (mistura de "terra + areia) em caixas, verificou-se que o procedimento potencialmente mais adequado foi o que envolveu a disposição das caixas lado a lado, no 
interior da câmara fria, com substrato e água previamente resfriados a $10^{\circ} \mathrm{C}$. $\mathrm{O}$ método de caixas empilhadas, sem o pré-resfriamento da água e do substrato, também foi selecionado, pois é o procedimento tradicionalmente utilizado no Brasil. Para o método da bandeja, os melhores procedimentos foram os que envolveram a utilização de apenas "terra" $(2 \mathrm{~kg})$ como substrato e utilização de "terra" ( $1 \mathrm{~kg})$ + papel tolha (22 folhas) como substrato, ambos com umidade do substrato ajustada para $70 \%$ da sua capacidade de retenção de água e conduzidos em ambiente controlado de temperatura, umidade relativa e luz. A segunda etapa da pesquisa foi conduzida com o objetivo de comparar os quatro procedimentos do teste de frio ( selecionados nas avaliações preliminares) com os testes de germinação padrão, envelhecimento acelerado e emergência das plântulas em campo. Os resultados obtidos permitiram concluir que o procedimento em bandeja oferece maior facilidade para padronização do que utilizando-se "terra" em caixas, permitindo a obtenção de resultados mais consistentes, inclusive quanto à relação com a emergência das plântulas em campo. Desta forma, pode ser utilizado, com segurança, na avaliação do potencial fisiológico das sementes de milho. 


\title{
ALTERNATIVE METHODOLOGIES OF THE COLD TEST FOR THE EVALUATION OF CORN SEED VIGOR
}

\author{
Author: ROSELI FÁTIMA CASEIRO \\ Adviser: Prof. Dr. JULIO MARCOS FILHO
}

\section{SUMMARY}

The objective of this research was to compare two procedures of the cold test to evaluate of corn seed vigor. For this, deep-box and tray method were used. The research was conducted at the Seed Analysis Laboratory of the Crop Science and Horticulture Department, Escola Superior de Agricultura "Luiz de Queiroz" (USP/ESALQ), Brazil. In the first study, preliminary tests were accomplished to compare several cold test procedures so as to select the more appropriate technique to be compared to other seed vigor tests routinely used for maize seeds. Variables included the prechilling of substrate, placing the boxes inside the cold room, the type and amount of substrate, water holding capacity of the substrate and controlled conditions (temperature, relative humidity, light) for seed germination after the cold period. Four protocols were selected. The procedure considered as more appropriate was deep-box disposed side by side, with substrate and water prechilled to $10^{\circ} \mathrm{C}$. The method where boxes were stacked, without prechilled water and substrate, was not as effective, even though this procedure have been traditionally used in Brazil. For the tray method, the best procedures involved the use of soil $(2 \mathrm{~kg})$ and soil $(1 \mathrm{~kg})$ 
with paper towels (22 leaves) as substrate, both with moisture content adjusted to $70 \%$ water holding capacity. The second study compared the four mentioned procedures for the cold test (selected in the preliminary evaluations) with germination, accelerated aging and seedling field emergence tests. Results showed that the cold test in trays offered greater potential for standardization than the cold test in deep-box. Results obtained were more consistent, besides showing the relationship with seedling emergence. This procedure is, therefore, considered as efficient for the evaluation of corn seed vigor. 


\section{INTRODUÇÃO}

A literatura e a experiência prática têm demonstrado que lotes de sementes, com percentagens de germinação semelhantes, podem apresentar desempenhos diferentes sob condições de campo e/ou durante o armazenamento. Essa ocorrência tem sido atribuída principalmente a variações no vigor das sementes e aos efeitos das condições do ambiente.

O teste de frio é um dos mais antigos e populares testes para avaliação do vigor de sementes. Foi desenvolvido, inicialmente, para avaliar o potencial fisiológico de sementes de milho e, posteriormente, adaptado para outras espécies, procurando simular condições desfavoráveis (excesso de água no solo, baixas temperaturas e ocorrência de fungos do solo) que ocorrem, com freqüência, durante a época de semeadura na área denominada Cinturão do Milho, nos EUA (Cícero e Vieira, 1994). A combinação entre alta umidade e baixa temperatura do solo tem sido associada com o desempenho deficiente de

lotes de sementes, especialmente em regiões de clima temperado, onde é freqüente a instalação de lavouras de milho no início da primavera (AOSA, 1983; Hampton e TeKrony, 1995).

Além de avaliar o potencial de desempenho das sementes em campo e selecionar lotes para semeadura, o teste de frio pode ainda ser usado para avaliar a eficiência de fungicidas (Meulen e Henke, 1948; Von Pinho et al., 1995); constituir parâmetro auxiliar para a seleção de materiais genéticos, em função de sua habilidade para germinar em solo úmido e frio (Pinnel, 1949); avaliar a deterioração resultante do armazenamento prolongado (Byrd e 
Delouche, 1971); avaliar os efeitos de danos causados pelo processo de secagem (Loeffler et al., 1985; Martin et al., 1988) e comportamento das sementes sob diferentes condições de armazenamento e tipos de embalagens (Baskin et al., 1987). Também tem sido usado para avaliar o vigor de sementes de soja, algodão, sorgo e outras espécies (Hampton e TeKrony, 1995).

No Brasil, esse teste tem sido utilizado por empresas produtoras de sementes, principalmente nos estados do sul e sudeste, onde lavouras de algodão, milho e soja podem ser semeadas entre o início do mês de setembro e meados de outubro. Nessa época, é comum a ocorrência de frentes frias chuvosas, as quais, dependendo do nível de vigor dos lotes de sementes, poderão provocar sérios problemas para a germinação e emergência de plântulas (Krzyzanowski et al, 1991).

O Comitê de Vigor da Association of Official Seed Analysts (AOSA, 1983) descreve procedimentos para a condução desse teste nos E.U.A; no entanto, o mesmo não tem sido padronizado entre diferentes laboratórios, que geralmente conduzem suas próprias versões do teste, ou seja, com o uso de diferentes temperaturas e períodos de exposição das sementes ao frio, tipos de substrato, uso ou não de "terra", métodos de distribuição de sementes (bandejas, papel toalha ou caixas). Essa diversidade de métodos tem contribuído para a desuniformidade dos resultados obtidos (Burris e Navratil, 1979).

No Brasil, também são encontradas variações da metodologia (Krzyzanowski et al, 1991; Cícero e Vieira, 1994; Dias e Barros, 1995), embora a maioria das análises seja conduzida utilizando-se a metodologia de "terra" em caixa. O método do rolo de papel, com e sem o uso de "terra", é utilizado esporadicamente e 0 método da bandeja praticamente não tem sido reconhecido no Brasil, embora seja o procedimento mais recomendado internacionalmente. Este método pode oferecer maior facilidade de padronização, controle mais adequado do umedecimento do substrato e, 
também, tem mostrado relação consistente com a emergência das plântulas em campo (Burris, 1990).

Diante do exposto, o presente trabalho teve a finalidade de estudar comparativamente as metodologias de "terra" em caixa e em bandeja, bem como suas relações com a emergência em campo, procurando verificar se a utilização dessa alternativa pode favorecer a reprodutibilidade dos resultados $e$, conseqüentemente, a confiabilidade das informações obtidas. $O$ objetivo básico foi a tentativa de atingir nivel de padronização mais consistente, em relação ao que tem sido obtido com os procedimentos habitualmente adotados no Brasil. 


\section{REVISÃO DE LITERATURA}

O teste de frio, utilizado para a avaliação do vigor de sementes, baseiase na exposição das sementes a baixas temperaturas $\left(10^{\circ} \mathrm{C}\right.$ durante 7 dias), em solos não esterilizados e com disponibilidade de água equivalente a, aproximadamente, $60 \%-70 \%$ da capacidade de campo. Considera-se que as

sementes vigorosas apresentam maior resistência a essas condições de ambiente. As condições de umidade e temperatura, simulam condições adversas que as sementes podem encontrar quando semeadas em campo, no início da primavera. A habilidade das sementes em germinar e emergir em solo relativamente frio e úmido é afetada pelo genótipo, atributos físicos e fisiológicos, presença de patógenos e tratamento químico de sementes (AOSA, 1983). Assim, teste de frio visa a avaliação dos efeitos da combinação desses fatores, identificando diferenças no potencial fisiológico de amostras de lotes de sementes.

\subsection{Procedimentos utilizado para a condução do teste de frio}

Os procedimentos utilizados para a condução do teste de frio têm sido constantemente modificados, visando, principalmente, obter maior nível de padronização para que os resultados possam ser seguros, confiáveis e reproduziveis entre diferentes laboratórios ou dentro de um mesmo laboratório. Dentre as variações da metodologia, destacam-se: 
a) "Terra" em caixa

Geralmente utiliza-se, como substrato, mistura de areia e terra (doravante chamada de "terra"), em proporções e capacidade de retenção de água que variam conforme o tipo de solo utilizado. Desta forma, Marcos Filho et al (1987) recomendam que, em solos com teores elevados de argila, a proporção da mistura deve ser ajustada para 3 partes de areia e 1 parte de "terra" e que a umidade seja equivalente a $60 \%$ da sua capacidade de retenção. Cicero e Vieira (1994) citam que, para solos arenosos, a preocupação com o controle da capacidade de retenção é menor e a irrigação pode ser feita sem o controle da quantidade de água, havendo necessidade, apenas, de que as caixas possuam, em sua base, perfurações suficientes para a drenagem do excesso de água.

Embora não exista recomendação para que se utilize apenas a areia como substrato, alguns trabalhos foram feitos neste sentido, com objetivo de obter maior nível de padronização no teste de frio (Waters e Blanchette, 1983; Bruggink et al., 1991; Lovato e Cagali, 1992; Lovato e Balboni, 1997).

A AOSA (1983) e Krzyzanowski et al (1991) recomendam o uso de caixas de $18 \times 25 \times 10 \mathrm{~cm}$ (ou similares) e a colocação, em cada uma, de camada com, aproximadamente, $2 \mathrm{~cm}$ de "terra" para a distribuição de 50 sementes. Posteriormente, a cobertura é feita utilizando-se a mesma quantidade de "terra". Cicero e Vieira (1994) indicam a utilização de caixas de $47 \times 30 \times 11 \mathrm{~cm}$, onde se podem efetuar divisões, cada uma comportando 50 ou 100 sementes. Após a obtenção do substrato, este é colocado nas caixas (camada de $7 \mathrm{~cm}$ ) para, em seguida, proceder-se à semeadura e cobertura das sementes com 2 a $3 \mathrm{~cm}$ do mesmo substrato. Por outro lado, o procedimento descrito por Dias e Barros (1995) envolve a utilização de caixas plásticas de 30 $\times 20 \times 10 \mathrm{~cm}$, com capacidade para $4000 \mathrm{~g}$ da mistura (3000g para a semeadura e 1000 g para a cobertura das sementes) e a distribuição de 50 sementes por caixa. 
Em todos os casos, após a semeadura, as caixas são colocadas em câmara fria regulada a $10^{\circ} \mathrm{C}$, durante 7 dias. Posteriormente, são transferidas para ambiente $\mathrm{a} \pm 25^{\circ} \mathrm{C}$ e a contagem de plântulas normais realizada aos 4 dias (AOSA, 1983; Krzyzanowski, 1991) ou aos 7 dias (Marcos Filho et al, 1987; Dias e Barros, 1995).

Os métodos que envolvem a utilização de uma camada mais espessa de "terra", permitem estimar que a quantidade de água distribuída, seja suficiente para o desenvolvimento das plântulas, sem a necessidade de controle da umidade relativa do ambiente onde as sementes são colocadas para germinar. As desvantagens normalmente citadas se referem à utilização de maiores quantidades de substrato e à necessidade de maior espaço para a condução do teste.

b) Rolo de papel com "terra"

Descrita pela primeira vez por Hoppe em 1955, a metodologia em rolo de papel com "terra" também tem sido modificada (Hampton e Tekrony 1995). Crosier (1957) conduziu o teste com algumas modificações na quantidade de "terra" utilizada, enquanto Fiala (1981) propôs a utilização de papel toalha com maior densidade e o ajuste da umidade do substrato para $40 \%$ da capacidade de retenção de água. Hampton e TeKrony (1995) prevêem a utilização de papel toalha de mesmo peso e espessura que o papel utilizado para o teste de germinação padrão.

Nesse procedimento, as sementes são distribuídas sobre duas folhas de papel toalha, da mesma maneira utilizada para o teste de germinação padrão; posteriormente, distribuem-se $300 \mathrm{~g}$ (Fiala, 1981) ou $60 \mathrm{ml}$ (Cicero e Vieira, 1994) de "terra" sobre as sementes; em seguida, cobre-se esse conjunto com uma a terceira folha de papel toalha e constitui-se cada rolo. Os rolos são colocados em caixas plásticas; estas são vedadas com fita adesiva e mantidas 
em câmara regulada a $10^{\circ} \mathrm{C}$ por 7 dias. De acordo com Fiala (1981), a umidade relativa no interior da câmara deve ser de $95 \%$, enquanto as caixas plásticas somente devem ser protegidas (vedadas ou colocadas em saco plástico) se a umidade relativa do ambiente não for controlada. Posteriormente, os rolos são transferidos para câmara de germinação regulada a $25^{\circ} \mathrm{C}$ e a contagem de plântulas normais realizada aos 13 dias (Fiala, 1981), 4 dias (AOSA, 1983), 5 dias (Hampton e Tekrony, 1995), ou 4 a 5 dias conforme Cicero e Vieira (1994).

Fiala (1981) e AOSA (1983) não especificam a quantidade de água a ser colocada no substrato. Cicero e Vieira (1994) citam que o umedecimento do substrato deve ser feito colocando-se quantidade de água equivalente a 2,0-2,5 vezes o peso do papel, enquanto Hampton e TeKrony (1995) sugerem que cada folha seja umedecida com $35 \mathrm{ml}$ de água. A água deve ser previamente resfriada a $10^{\circ} \mathrm{C}$ (AOSA, 1983; Cicero e Vieira, 1994; Hampton e TeKrony, 1995).

Este método tem sido utilizado nos E.U.A (Burris, 1990) e na Europa (Woodstook, 1976, citado por Cicero e Vieira, 1994), pois tem a vantagem de utilizar uma quantidade pequena de substrato, ocupar menos espaço no laboratório e apresentar relação satisfatória com outros procedimentos utilizados para condução do teste de frio e com os resultados da emergência das plântulas em campo. Segundo Crosier (1957) o método pode, ainda, proporcionar avaliação mais rápida e segura das plântulas, quando comparado com o método de "terra" em caixa (plastic boxes) mas consome mais tempo para sua instalação. Segundo Woltz (1997), outra desvantagem pode ser a dificuldade de distribuir uma camada uniforme de "terra" sobre as sementes, além da possível secagem excessiva dos rolos antes da avaliação das plântulas. 
c) Rolo de papel, sem "terra"

Waters e Blanchette (1983), foram os primeiros a utilizarem este procedimento, com sementes de milho doce. De acordo com Cicero e Vieira (1994), a distribuição das sementes no substrato é feita da mesma forma adotada para o teste de germinação padrão e, após a semeadura, os rolos são colocados em caixas plásticas. Estas, posteriormente, são vedadas e mantidas em câmara regulada a $10^{\circ} \mathrm{C}$ por 7 dias (ou por 4 dias conforme Waters e Blanchette, 1983). Posteriormente, os rolos são transferidos para câmaras de germinação reguladas a $25^{\circ} \mathrm{C}$ e a contagem de plântulas normais realizada aos 4 dias (Waters e Blanchette, 1983; Dias e Barros, 1995), 6 dias (Loeffler et al, 1985) ou 4 a 5 dias, conforme Marcos Filho et al (1987) e Cicero e Vieira (1994).

Para o umedecimento do substrato, Loeffler et al (1985) utilizaram $35 \mathrm{ml}$ de água por folha de papel toalha. Marcos Filho et al (1987) e Cicero e Vieira (1994) recomendam a mesma quantidade de água descrita para o método em rolo de papel toalha com "terra", enquanto Dias e Barros (1995) indicam quantidade equivalente a 3 vezes o peso seco do papel.

O teste de frio, sem a utilização de "terra", tem efeitos menos drásticos que os observados em testes com terra; entretanto, apresenta algumas características importantes de um teste de vigor como, por exemplo, sensibilidade, reprodutibilidade dos resultados e simplicidade de execução (Loeffler et al, 1985). O teste de frio sem a utilização de "terra" geralmente detecta apenas diferenças acentuadas de qualidade das sementes (Medina e Marcos Filho, 1990). Este método pode não ser eficiente para a avaliação de tratamento fungicida. 
d) Método do "substrato em bandeja"

Tornou-se conhecido no final dos anos 70, conforme Burris e Navratil (1979), mas a descrição a seguir é feita de acordo com AOSA (1983). Utilizamse bandejas de restaurante tipo "fast-food" com $66 \times 45 \times 2,5 \mathrm{~cm}$. Na base da bandeja, coloca-se uma folha $(40 \times 61 \times 0,5 \mathrm{~cm})$ de papel "Kimpak", embebida com $1100 \mathrm{ml}$ de água deionizada, resfriada a $10^{\circ} \mathrm{C}$. São distribuídas duas amostras de 100 ou 200 sementes sobre o papel, posteriormente cobertas com o substrato (mistura de terra e areia). Vieira et al (1991), trabalhando com sementes de soja, utilizaram 2 amostras de 50 sementes e $500 \mathrm{ml}$ de água para o umedecimento do papel. Neste caso, Cicero e Vieira (1994) citam que a quantidade de substrato utilizada para cobrir as sementes deve ser de $240 \mathrm{ml}$; o substrato deve apresentar um teor de água ao redor de 12\%. A AOSA (1983) e Hampton e TeKrony (1995) não especificam a quantidade de substrato a ser utilizada. Modificações deste procedimento também foram feitas por Woltz (1997), quando utilizou bandejas de $33 \times 45,7 \mathrm{~cm}$ e 2 folhas de papel de "Kimpak" $(30,5 \times 43,2)$ umedecidas com $400 \mathrm{ml}$ de água deionizada e resfriada a $10^{\circ} \mathrm{C}$.

Após a semeadura, as bandejas são colocadas em carrinhos fechados (tipo "fast-food"), com prateleiras espaçadas entre si de 7,5 a $10 \mathrm{~cm}$, e mantidas em câmara fria a $10^{\circ} \mathrm{C}$, durante 7 dias. Posteriormente são transferidas para câmaras a $25^{\circ} \mathrm{C}$ (com pelo menos 8 horas de luz por dia) e, a avaliação, feita aos 4 dias. A avaliação das plântulas feita no quinto dia parece trazer melhores resultados (Cicero e Vieira, 1994).

Embora o teste exija mais espaço do que procedimento em rolos de papel, apresenta características vantajosas, incluindo: padronização da umidade do substrato; distribuição uniforme das sementes no substrato, permitindo uma fácil interpretação; emergência natural das plântulas através do substrato areia-terra, permitindo avaliação rápida e precisa; eficiência (menos tempo por teste) e maior grau de controle das condições ambientais. Os 
resultados obtidos com o método da bandeja têm se relacionado com os de emergência das plântulas em campo e com os de outros procedimentos usados no teste de frio.

A principal limitação é o custo inicial com a aquisição de equipamentos (Burris, 1990). Outra desvantagem do método, citada por Woltz (1997), é a necessidade do controle da umidade relativa no interior da câmara de germinação, para assegurar que o substrato não se desidrate excessivamente. Por utilizar apenas uma fina camada de "terra", a água pode evaporar facilmente, se a umidade relativa do ambiente for baixa. Tal fato pode prejudicar a germinação e/ou 0 desenvolvimento das plântulas, levando a resultados pouco consistentes.

e) Teste de frio com substrato saturado (Pioneer cold test)

Foi descrito pela primeira vez por Martin et al., (1988), mas desenvolvido entre 1935 e 1938, como método auxiliar na avaliação de genótipos tolerantes ao frio. O procedimento apresentado em seguida foi descrito por Woltz (1997).

Em uma bandeja de $33 \times 45,7 \mathrm{~cm}$ (tipo "fast-food") colocam-se $500 \mathrm{ml}$ de água deionizada e resfriada a $10^{\circ} \mathrm{C}$. No interior da bandeja coloca-se um suporte de plástico $(27,5 \times 41 \times 2 \mathrm{~cm})$, envolvido por uma folha de papel toalha $(30,5 \times 61 \mathrm{~cm})$ previamente resfriada e saturada $\left(10^{\circ} \mathrm{C}\right.$ por 24 horas $)$. Posteriormente, outra folha de papel toalha $(30,5 \times 45,7 \mathrm{~cm})$, também previamente umedecida, é colocada sobre o suporte. As extremidades de ambas as folhas ficam em contato com a água que está no fundo da bandeja. Aproximadamente $250 \mathrm{ml}$ de "terra" são distribuídos em um fina camada sobre as folhas de papel toalha, sendo a semeadura feita logo em seguida, com duas amostras de 50 sementes (amostras de lotes distintos). As sementes são posicionadas com a parte plana apoiada no substrato. Em seguida, as bandejas são colocadas em um carrinho (tipo "fast-food") e mantidas em ambiente a $10^{\circ} \mathrm{C}$ 
por 7 dias. Após este período, são transferidas para câmaras de germinação reguladas a $25^{\circ} \mathrm{C}\left( \pm 5^{\circ} \mathrm{C}\right)$ com luz contínua e a avaliação feita aos 5 dias. Martin et al (1988) utilizaram condições de umidade relativa controlada (85\%) e temperatura de $27^{\circ} \mathrm{C}$ durante o período de germinação das sementes.

As vantagens deste procedimento são a distribuição uniforme de água por todo o substrato e a utilização de pequena quantidade de terra. Embora por muitos anos tenha sido considerado um teste eficiente para selecionar genótipos de milho com alto potencial para germinação em solo úmido e frio, é um teste caro, consome mais tempo e de difícil execução (Martin et al, 1988); exige também câmara com umidade relativa controlada, para reduzir a evaporação da água do substrato (Woltz, 1997).

Considerando os procedimentos descritos, verifica-se que há variações com relação ao tamanho dos recipientes, à quantidade de "terra" utilizada, à quantidade de água a ser adicionada no substrato e, também, ao número de dias necessários para a avaliação das plântulas. De um modo geral, as metodologias propostas foram mais consistentes quanto à temperatura $\left(10^{\circ} \mathrm{C}\right) \mathrm{e}$ o período ( 7 dias) em que as sementes foram expostas a essa condição.

\subsection{Comparação entre procedimentos}

Vários trabalhos têm sido conduzidos para comparar as metodologias disponiveis para a execução do teste de frio e identificar as que melhor detectam possiveis diferenças entre niveis de vigor, permitem estimar o potencial de emergência das plântulas em campo, acusam danos durante a secagem e apresentam relativa padronização dos resultados dentro e entre laboratórios.

Crosier (1957) encontrou variabilidade nos resultados do teste de frio, observando que as amostras analisadas apresentaram comportamentos 
distintos entre os métodos de rolo de papel tolha com "terra" (88\%), "terra" em caixa $(83 \%)$ e com o método conduzido em substrato inundado $(72 \%)$. Neste caso, o autor pretendeu simular as condições de chuva forte logo após a semeadura, com posterior queda da temperatura ambiente.

As variações nos resultados podem existir não somente quando se utilizam procedimentos diferentes; estas também podem ser verificadas entre laboratórios que utilizam o mesmo procedimento. Tal fato foi constatado por Burris e Navratil (1979), quando compararam vários protocolos para o teste de frio entre nove laboratórios de análise de sementes. Os autores verificaram que através do método recomendado pela AOSA (substrato em caixa), a mesma amostra de sementes, depois de submetida à baixa temperatura, apresentou $38 \%$ de germinação em um laboratório e $96 \%$ em outro. Quanto aos diferentes procedimentos utilizados, resultados mais consistentes foram obtidos quando diferentes métodos foram usados no mesmo laboratório e com a mesma fonte de solo, sendo que os valores foram semelhantes para o método da bandeja $(86 \%)$, solo em caixa ( $85 \%)$ e rolo de papel com "terra" $(88 \%)$.

Waters e Blanchette (1983) verificaram que, para sementes de milho doce, tanto o teste de frio em caixa com areia esterilizada como em rolo de papel sem "terra", se relacionaram com a emergência das plântulas em campo; a avaliação do teste de frio, foi feita com base na matéria seca das plântulas. $O$ teste em rolo de papel sem "terra" foi considerado mais prático, pois requer menos espaço e tempo que os procedimentos que envolvem areia ou "terra".

Dois procedimentos para o teste de frio foram comparados por Loeffler et al (1985) para avaliar qual seria mais eficiente para detectar injúrias causadas durante o processo de secagem de sementes de milho. Embora os resultados tenham sido similares entre o teste de frio em rolo de papel toalha sem e com "terra", este último apresentou variações mais amplas em função do substrato utilizado e, se mostrou um pouco mais severo. Considerando que o teste de frio sem "terra" também foi sensivel para detectar reduções na porcentagem de 
germinação provocadas pelos danos durante a secagem, este pareceu ser mais praticável, devido à obtenção de resultados consistentes e pela simplicidade de execução.

Em trabalho de aferição de testes de vigor para sementes de milho, Barros e Dias (1992) constataram que, de modo geral, os laboratórios obtiveram melhores resultados quando utilizaram teste de frio em rolo de papel sem "terra". O método de "terra" em caixa proporcionou maiores variações, embora a classificação dos lotes tenha sido semelhante. Posteriormente, o mesmo tipo de trabalho foi feito por Barros e Dias (1996). Entretanto, os resultados foram diferentes, visto que para a maioria dos laboratórios, não foi possivel detectar diferenças entre os lotes, quando utilizaram as mesmas metodologias já citadas. Segundo os autores, a pequena diferença de vigor entre os lotes, pode ter contribuido para a obtenção desses resultados.

Apesar das vantagens apresentadas para o teste de frio em rolo de papel toalha sem "terra", alguns trabalhos mostram que este teste, permite caracterizar apenas diferenças acentuadas de qualidade de sementes (Medina e Marcos Filho, 1990). Esses autores citam que o teste de frio envolvendo "terra" (método de "terra" em caixa), apesar de mais severo, é mais eficiente em identificar o potencial de emergência das plântulas em campo, potencial de armazenamento e também em separar lotes de sementes com diferentes niveis de vigor.

Em estudos feitos por Molina et al (1987), o teste de frio tradicional (terra + areia em caixas, $7^{\circ} \mathrm{C}$ a $10^{\circ} \mathrm{C}$ por 7 dias), apesar de ser mais drástico, foi mais eficiente para separar lotes de sementes de milho com diferentes niveis de potencial fisiológico, quando comparado com dois outros métodos (rolo de papel toalha sem terra, a $10^{\circ} \mathrm{C}$ por 5 dias, e $7^{\circ} \mathrm{C}$ a $10^{\circ} \mathrm{C}$ por 7 dias). Em relação a esses dois últimos, o uso de frio por 7 dias $\left(7^{\circ} \mathrm{C}\right.$ a $\left.10^{\circ} \mathrm{C}\right)$, o qual oferece condições mais estressantes, foi o mais sensivel em detectar tais diferenças. 
Embora a diferença entre laboratórios tenha sido significativa, a classificação de lotes de sementes de milho, ervilha e feijão-fava foi similar quando utilizou-se a metodologia em rolos de papel toalha com terra, mantidos a $8^{\circ} \mathrm{C}$ por 7 dias, seguido por germinação a $20^{\circ} \mathrm{C}$ por 8 dias. Para sementes de ervilha e feijão-fava, os resultados do teste de frio se relacionaram aos resultados da emergência das plântulas em campo. O mesmo não foi observado para sementes de milho, onde a relação foi inconsistente (Fiala, 1987).

Diferenças no vigor de lotes de sementes de beterraba, foram constatados através do teste de frio em bandejas, utilizando-se apenas areia como substrato $\left(7\right.$ dias à $8^{\circ} \mathrm{C}$ e 7 dias à $20^{\circ} \mathrm{C}$ ), sendo que o mesmo mostrou relação com a emergência das plântulas em campo; no entanto, quando foi conduzido em papel (14 dias à $9^{\circ} \mathrm{C}$ ), os resultados não foram seguros para avaliar o vigor (Lovato e Cagalli, 1992). O teste de frio em areia sobre bandejas também foi utilizado por Lovato e Balboni (1997); esta metodologia, quando comparada com o teste de frio tradicional, foi eficiente para detectar diferenças de vigor entre lotes de sementes de milho e, também, para avaliar o desempenho das sementes em condições adversas de campo.

Byrum e Copeland (1995) verificaram que, dentro de um mesmo laboratório, onde os métodos podem ser padronizados, a variabilidade do teste de frio é reduzida. Sugeriram que as tolerâncias usadas para $\circ$ teste de germinação padrão também poderiam ser aplicadas ao teste de frio, pois observaram que as variações entre os resultados deste teste não foram mais amplas que as obtidas para o teste de germinação padrão.

Resultados de trabalho conduzido por Woltz (1997), mostraram que, quando os patógenos do substrato foram eliminados através da esterilização, não houve diferenças significativas entre as metodologias avaliadas ("terra" em caixa, rolo de papel com "terra", bandeja e teste de frio com substrato saturado). 
Quando foram utilizadas sementes tratadas com fungicidas também não houve diferenças entre as metodologias.

Condições mais drásticas de temperatura, período de exposição a baixas temperaturas e também a presença de "terra" (ou mistura "terra" + areia), parecem aumentar a sensibilidade do teste de frio em distinguir lotes de sementes com diferentes níveis de vigor. Métodos que utilizam substrato esterilizado ou que não incluem o uso de "terra", são menos severos. Porém, nem sempre são eficientes em detectar diferenças de vigor.

Quando diferentes metodologias são conduzidas dentro de um mesmo laboratório, as variações entre os resultados são menos expressivas, o que provavelmente, ocorra em função da utilização do mesmo tipo de "solo". A variabilidade dos resultados é mais pronunciada quando a comparação é feita entre laboratórios. Mas, em alguns casos, apesar da diferença significativa entre laboratórios, a classificação dos lotes em diferentes níveis de qualidade fisiológica foi consistente, conforme relatado por Fiala (1987).

Há certas dificuldades para padronização desses procedimentos, dentre as quais podem se destacar: a utilização de diferentes tipos de solo; as espécies e a população de microorganismos presentes no solo são variáveis de acordo com o tipo de solo, condições climáticas e região de cultivo; o período de exposição das sementes às baixas temperaturas, a umidade do substrato, a proporção "terra"/areia e a temperatura utilizada não foram, ainda, perfeitamente estabelecidos; sementes de diferentes espécies e cultivares podem apresentar comportamento variável quando expostas às baixas temperaturas; pode haver variação do produto utilizado para o tratamento fungicida das sementes e, assim, o nível de controle de microorganismos presentes no solo pode ser alterado. Por outro lado, dependendo da causa determinante da baixa qualidade das sementes, ou seja, injúrias mecânicas, temperatura de secagem, grau de maturidade, sanidade, ambiente de 
armazenamento, a resposta poderá ser mais ou menos drástica, dificultando a interpretação dos resultados (Marcos Filho et al., 1987).

Outro aspecto que ainda não está bem definido é a necessidade ou não do resfriamento do solo, previamente à semeadura do teste de frio. Metodologias descritas pela AOSA (1983), Cícero e Vieira (1994), Dias e Barros (1995) e Hampton e TeKrony (1995), recomendam o resfriamento da água até $10^{\circ} \mathrm{C}$ antes da semeadura, mas não há proposta para a temperatura do substrato. Já Krzyzanowski et al., (1991) recomendam tanto o resfriamento da água como o do substrato a $10^{\circ} \mathrm{C}$, antes da instalação do teste. A metodologia usualmente empregada em laboratórios brasileiros não prevê o préresfriamento da água e o do substrato.

Tem sido verificado que, como o teste de frio envolve o uso de terra, que apresenta alta variabilidade, tanto física quanto biológica, sua padronização completa não é tarefa simples, podendo ser considerado como o fator preponderante para dificultar a obtenção de resultados uniformes entre laboratórios (Hampton e TeKrony, 1995).

\subsection{Fatores que afetam os resultados do teste de frio}

O substrato é um aspecto muito importante do teste de frio e a seleção de uma fonte apropriada de "terra" é crítica para a reprodutibilidade do teste. Solos altamente orgânicos podem apresentar excessiva atividade de patógenos, podendo fornecer resultados menos consistentes. Para o teste de frio conduzido em caixas, o substrato (mistura de terra e areia) é a principal fonte de água, mostrando que tanto a capacidade de campo como a porosidade são fatores que exigem controle cuidadoso (Burris, 1990).

A padronização do teste de frio tem sido alvo de estudo de vários pesquisadores, mas os resultados obtidos geralmente são divergentes. 
O solo contém numerosas espécies de Pithyum e raças da mesma espécie, que agem de maneira semelhante na deterioração das sementes, mas variam quanto à virulência. Os resultados do teste têm variado de acordo com a quantidade e os níveis de virulência das espécies e raças de microorganismos presentes no substrato (Desai e Reddy, 1958).

Hooks e Zuber (1963) observaram que solos de áreas com histórico de rotação de culturas, proporcionaram porcentagens de germinação mais altas após o período de frio; solos cultivados constantemente com milho resultaram em porcentagens mais baixas de germinação, indicando que a população ou virulência dos microorganismos sofreram aumento com a prática da monocultura do milho.

Resultados diferentes foram encontrados por Nijenstein (1985; 1988), onde reduções na porcentagem de germinação, foram obtidas de solos nos quais o milho não havia sido cultivado por muitos anos. Solos de pastagem causaram considerável mortalidade nas sementes e foram mais eficientes para discriminar lotes com diferentes níveis de vigor. Tal fato contradiz a recomendação de que o substrato utilizado deve ser proveniente de áreas onde a cultura foi instalada recentemente, para assegurar que os microorganismos estejam presentes no teste de frio.

Burris e Navratil (1979) verificaram que o substrato ("terra" ou mistura "terra" + areia) é um dos principais componentes que dificultam a padronização deste teste; ao compararem substrato esterilizado e não esterilizado, verificaram que os resultados foram similares. Desta forma, constataram que o desempenho da semente foi afetado principalmente pelo estresse causado pela temperatura e muito pouco pela presença de microorganismos. Os autores ainda propuseram o desenvolvimento de uma metodologia apenas com o efeito da baixa temperatura, sem a utilização de terra, o que diminuiria as variações entre os resultados obtidos em diferentes laboratórios. 
A redução da germinação no teste de frio tem sido atribuída principalmente à presença e atividade dos microorganismos (Tao, 1978; Nijënstein, 1985; Bruggink et al, 1991; Woltz, 1997). Portanto, a utilização de solos não cultivados com a cultura a ser analisada, podem resultar em porcentagem de germinação superior em relação à observada no campo, visto que microorganismos patogênicos que normalmente se associam à cultura na época da semeadura, podem não estar presentes. Características importantes do teste de frio, como a avaliação de lotes com diferentes níveis de vigor, influência da umidade e temperatura do substrato e eficiência de diferentes produtos químicos utilizados no tratamento de sementes, não foram detectados em substratos esterilizados (Woltz, 1997). Em vista disso, metodologias conduzidas com substrato esterilizado (ou sem a utilização deste), podem não se constituir em alternativas confiáveis quando o objetivo é a padronização do teste.

Outro fator que pode influenciar os resultados é o conteúdo de água do substrato. Resultados de teste de frio utilizando substrato com potencial hídrico equivalente a $52 \%$ da capacidade de campo, mostraram estreita relação com a emergência das plântulas de soja em campo. No entanto, em substrato mais seco ( $42 \%$ da capacidade de retenção de água) houve queda significativa na emergência das plântulas (Tao, 1978).

Em estudos feitos por Nijenstein (1985), a menor porcentagem de germinação obtida no teste de frio foi em substrato com umidade ajustada para $55 \%$ da capacidade de retenção. Em outro trabalho realizado pelo mesmo autor (Nijenstein, 1988), o melhor desempenho da semente foi verificado em substrato com $34 \%$ de sua capacidade de retenção de água. Acima desse valor, houve decréscimo na média da germinação de todos os lotes. Bruggink et al (1991) verificou que as diferenças de vigor entre lotes foram mais pronunciadas em substrato com capacidade de retenção entre 50 e $75 \%$. 
A variabilidade na determinação da capacidade de campo pode levar alguns laboratórios a usarem substratos excessivamente úmidos; a distribuição de sementes em solos com condições anaeróbicas pode reduzir a germinação no teste de frio (Woltz, 1997). Por outro lado, Hooks e Zuber (1963) não detectaram diferenças na germinação de sementes de milho em substratos com diferentes níveis de água.

Variações na temperatura e no período de exposição também podem fornecer condições mais ou menos drásticas ao teste $e$ influenciar os resultados. Nijënstein (1988) cita que quanto mais longo for o período e exposição ao frio, mais acentuados serão os prejuizos para as sementes de milho. A temperatura de $8,8^{\circ} \mathrm{C}$ e um curto período de frio ( 3 dias), foram mais efetivos para detectar diferenças de vigor entre lotes de sementes de milho do que temperaturas entre $8,8^{\circ} \mathrm{C}$ e $15^{\circ} \mathrm{C}$; temperaturas superiores a $15^{\circ} \mathrm{C}$ não foram eficientes (Bruggink et al, 1991).

Os efeitos da temperatura durante o período de embebição no teste de frio (primeiros 7 dias) foram mais pronunciados quando sementes não tratadas foram utilizadas em solos não esterilizados (Woltz, 1997). A germinação após a exposição ao frio foi mais baixa a $9^{\circ} \mathrm{C}(58 \%)$ e mais alta a $4,5^{\circ} \mathrm{C}(90 \%)$ e $13^{\circ} \mathrm{C}$ $(82 \%)$. Para sementes tratadas, houve apenas 6 pontos percentuais de diferença na média da germinação de todos os lotes, sendo que a maior porcentagem foi obtida a $5^{\circ} \mathrm{C}$ e a menor a $11^{\circ} \mathrm{C}$. Haskell (1948) e Hoppe (1951) também observaram maior porcentagem de germinação a $4,4^{\circ} \mathrm{C}$ do que a $10^{\circ} \mathrm{C}$. Os autores explicam que temperaturas em torno de $10^{\circ} \mathrm{C}$ são favoráveis ao desenvolvimento de microorganismos, permitindo a infecção das sementes e reduzindo a germinação; $a 4,5^{\circ} \mathrm{C}$ há inibição do crescimento de patógenos.

A aplicação de produtos químicos nas sementes submetidas ao teste de frio, se constitui em outro fator de interferência nos resultados. O tratamento das sementes pode agir diretamente sobre os microorganismos presentes no solo, anulando os efeitos provocados na germinação das sementes. Bruggink et 
al (1991), constataram que o tratamento fungicida promoveu maiores porcentagens de germinação, quando o teste de frio foi conduzido utilizando-se "terra" como substrato; em substrato esterilizado, este efeito não foi verificado. A dosagem e o tipo de produto químico também podem influenciar os resultados.

Woltz (1997) verificou redução na germinação de sementes não tratadas conforme foi aumentando o nivel de água do solo (48 pontos percentuais entre o nivel mais alto e o nivel mais baixo de água no solo). Para sementes tratadas este efeito não foi tão pronunciado, mostrando que a presença de patógenos foi responsável pela redução na germinação do teste de frio de sementes não tratadas. $O$ aumento na porcentagem de germinação do teste de frio, devido ao tratamento das sementes, também foi observado por Meulen e Henke (1948), Hoppe (1951) e Crosier (1957).

Em relação aos fatores que afetam os resultados do teste de frio com "terra", percebe-se que estudos com o mesmo objetivo podem chegar a resultados completamente diferentes, dependendo principalmente da quantidade de água a ser adicionada ao substrato. Quanto aos microorganismos presentes no solo, verifica-se que esse fator é a principal causa da redução da germinação e que sua presença no teste de frio é fundamental, não sendo conveniente, portanto, a utilização de substratos esterilizados, pois estes podem mascarar os resultados. Embora o tratamento das sementes anule certos efeitos provocados pela temperatura do período de frio, por microorganismos do solo e até mesmo o conteúdo de água no solo, o uso de sementes tratadas não se constitui em um problema, pois o teste é considerado útil para avaliar efeitos do tratamento fungicida. É importante ressaltar que o tratamento empregado deve, preferencialmente, ser o mesmo que as sementes receberão antes da semeadura no campo. 


\section{MATERIAL E MÉTODOS}

O presente trabalho foi conduzido no laboratório de Análise de Sementes do Departamento de Produção Vegetal, Escola Superior de Agricultura "Luiz de Queiroz" (USP/ESALQ). O experimento constou de duas fases: testes preliminares e comparação do teste de frio com outros métodos para a avaliação do vigor.

\subsection{Observações preliminares sobre teste de frio "em caixas"}

Foram realizados para verificar a influência do pré-resfriamento do substrato para a semeadura do teste de frio e, também, da disposição das caixas no interior da câmara fria. Essas observações se destinaram à identificação de procedimento (s) potencialmente mais adequado (s) para a condução do teste de frio na segunda etapa do projeto (item 3.3).

\section{A) Estudo do pré-resfriamento do substrato}

Esta etapa constou da verificação de três alternativas, a saber: "substrato sem pré-resfriamento, umedecido com água a temperatura ambiente" (T1), "substrato sem pré-resfriamento, umedecido com água pré-resfriada a $10^{\circ} \mathrm{C}$ " (T2) e "substrato e água pré-resfriados a $10^{\circ} \mathrm{C}$ " (T3). Para esta avaliação, foram utilizadas oito repetições por tratamento, perfazendo um total de 24 caixas ( $47 x$ $30 \times 11 \mathrm{~cm}$ ). Como substrato, foram utilizados aproximadamente $16 \mathrm{~kg} \mathrm{da}$ mistura terra e areia (doravante chamada de "terra"), na proporção 3:1 (3 partes de areia para 1 parte de terra). A terra foi coletada de área anteriormente 
cultivada com milho. Para o tratamento $\mathrm{T} 1$, o substrato foi colocado nas caixas para, em seguida, proceder-se a semeadura e a cobertura das sementes com 2 a $3 \mathrm{~cm}$ do mesmo substrato. A irrigação foi feita através do ajuste da disponibilidade de água do substrato para $60 \%$ da capacidade de retenção. Esse cálculo foi feito com de acordo com as Regras para Análise de Sementes (Brasil, 1992).

O mesmo procedimento foi adotado para o tratamento T2. Para o tratamento T3, as caixas contendo o substrato, foram colocadas em câmara fria, até que este atingisse a temperatura de $10^{\circ} \mathrm{C}$. Posteriormente, foram retiradas da câmara, para que se procedesse rapidamente à semeadura (o ajuste da disponibilidade de água foi feito da mesma forma descrita anteriormente) e, após esta operação, todos os tratamentos foram reconduzidos para a câmara fria.

A comparação desses procedimentos envolveu a semeadura de duas amostras de 50 sementes por caixa; utilizou-se apenas um lote do mesmo cultivar para todos os tratamentos.

\section{B) Estudo da disposição das caixas no interior da câmara fria}

Neste caso, ao serem colocadas na câmara fria, quatro caixas (repetições) correspondentes a cada uma das três alternativas estudadas (descritas no item 3.1-a) foram dispostas lado a lado (figura 01) e outras quatro foram superpostas, formando pilha (figura 02). Durante a permanência no interior da câmara, foi feito o monitoramento da temperatura para verificar qual o período necessário para o substrato atingir $10^{\circ} \mathrm{C}$; com um termômetro digital, a temperatura foi determinada separadamente em cada caixa, com intervalos de 120 minutos, por um período de 8 horas. Essa avaliação também foi feita para o substrato já resfriado pois, durante a semeadura, as caixas permaneceram à 


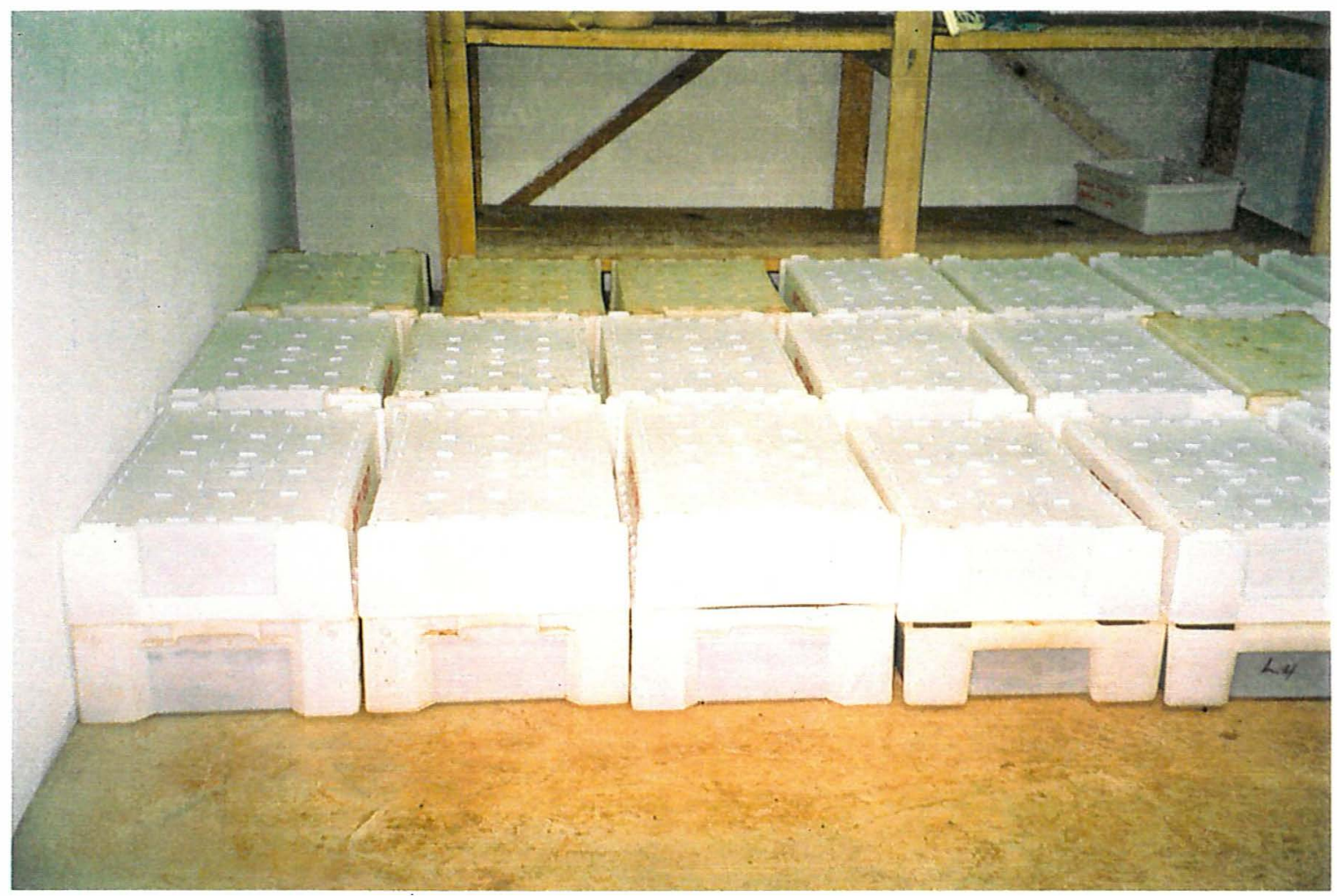

Figura 1. Caixas dispostas lado a lado no interior da câmara fria.

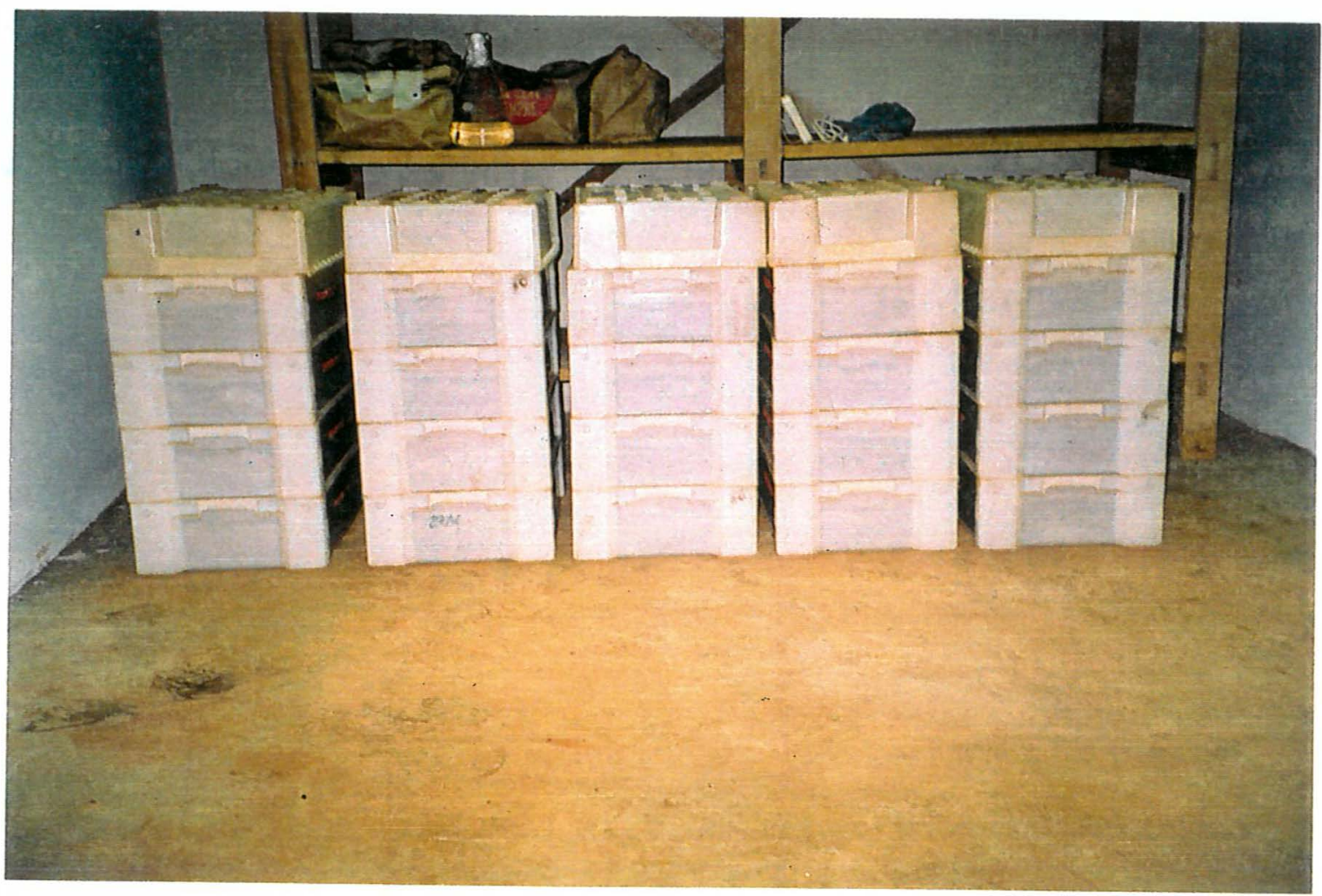

Figura 2. Caixas superpostas (formando pilha) no interior da câmara fria. 
temperatura ambiente até o término desta operação; nesse intervalo de tempo, poderiam haver variações da temperatura do substrato. Após 26 horas da instalação do teste e, também, antes das caixas serem transferidas da câmara fria para ambiente a $\pm 25^{\circ} \mathrm{C}$ (168 horas após a instalação do teste), a temperatura do substrato de todas as caixas foi determinada novamente, para verificação da possível ocorrência de variações.

Após 7 dias de permanência na câmara a $10^{\circ} \mathrm{C}$, a germinação foi conduzida a $25^{\circ} \mathrm{C}$ por 7 dias, computando-se as porcentagens de plântulas normais correspondentes a cada tratamento.

\subsection{Observações preliminares sobre teste de frio "em bandejas"}

Nesta etapa, foram realizadas observações para verificar o tipo, quantidade e também a capacidade de retenção de água do substrato adequados para esta metodologia. Condições controladas de umidade relativa e temperatura, a presença ou não de luz durante a germinação das sementes, também foram avaliadas nessa ocasião. A combinação mais favorável desses fatores foi utilizada na etapa 3.3 desta pesquisa.

\section{A) Estudo do tipo e quantidade de substrato a ser utilizado}

Bandejas com dimensões de $45 \times 66 \times 2 \mathrm{~cm}$ e papel "Kimpak" de $40 \times 61$ x 0,5 cm são recomendados pela AOSA (1983) e por Cicero e Vieira (1994) para o procedimento do teste de frio em bandeja. Como não foi possivel a obtenção desses materiais para a realização do experimento, algumas modificações foram feitas com relação ao tamanho da bandeja e ao papel utilizado como substrato. Neste caso, foram utilizadas bandejas de $34 \times 23 \times 7$ $\mathrm{cm}$ e folhas de papel toalha adaptadas para o tamanho da bandeja $(26,5 \times 18,5$ $\mathrm{cm})$.

Três tratamentos foram avaliados, a saber: 
a) utilização de 6 folhas de papel toalha $+1 \mathrm{~kg}$ de "terra";

b) utilização de 12 folhas de papel toalha + $1 \mathrm{~kg}$ de "terra";

c) utilização de $2 \mathrm{~kg}$ de "terra".

Para esta avaliação foram utilizadas amostras de dois lotes de sementes de milho. Para os tratamentos a e $b$, no fundo da bandeja foram colocadas as folhas de papel toalha, umedecidas com quantidade de água equivalente a 2,5 vezes 0 seu peso. Em cada bandeja foram distribuídas 2 amostras de 50 sementes (uma repetição de cada lote), em seguida cobertas com $1 \mathrm{~kg}$ de "terra". A disponibilidade de água deste substrato, foi ajustada para $60 \%$ de sua capacidade de retenção. A água utilizada foi previamente resfriada a $10^{\circ} \mathrm{C}$. Para o tratamento c, no fundo da bandeja foi colocado $1 \mathrm{~kg}$ de "terra", sendo que a distribuição e cobertura das sementes e também, o ajuste da umidade do substrato foram feitos da mesma forma descrita anteriormente. Foram utilizadas duas bandejas por tratamento.

Para reduzir evaporação, as bandejas foram protegidas com saco plástico, sendo, em seguida, transferidas para câmara fria a $10^{\circ} \mathrm{C}$ por 7 dias. Um carrinho de laboratório foi adaptado para comportar as bandejas no interior da câmara fria (figura 03). O monitoramento da temperatura do substrato, foi realizado 1 e 2 horas após a instalação do teste, utilizando-se um termômetro digital. Após o período de esfriamento, as bandejas foram transferidas para ambiente a $\pm 25^{\circ} \mathrm{C}$ e a avaliação foi feita aos 7 dias, computando-se as percentagens de plântulas normais correspondentes a cada tratamento.

Posteriormente um quarto tratamento foi avaliado, mantendo a quantidade de "terra" $(1 \mathrm{~kg}$ ) e aumentando para 22 a quantidade de folhas de papel toalha. $O$ tratamento $c$ foi instalado novamente para efeito comparativo. Amostras de dois lotes de sementes de milho foram utilizadas para esta avaliação (os lotes não foram os mesmos utilizados na avaliação anterior). 0 procedimento adotado foi o mesmo já descrito mas, neste caso, avaliaram-se 4 repetições de 50 sementes por tratamento. 


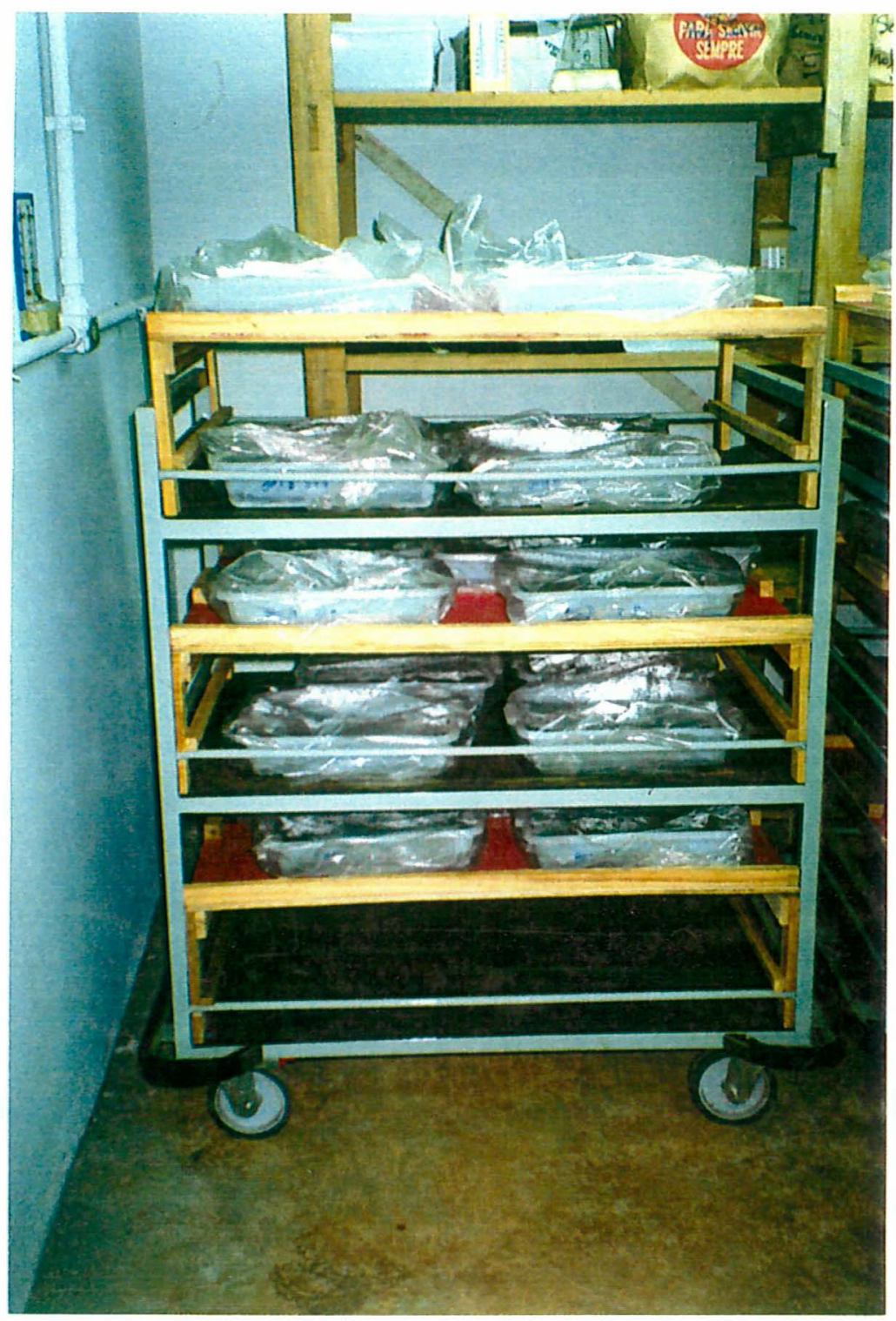

Figura 3. Carrinho de laboratório adaptado com prateleiras, para comportar as bandejas no interior da câmara fria. 


\section{B) Estudo da capacidade de retenção de água do substrato "terra"}

Esta etapa teve o objetivo de comparar a germinação das sementes em substrato com diferentes níveis de capacidade de retenção de água, mantidos em ambiente não controlado de temperatura e umidade relativa.

Os tratamentos avaliados são especificados a seguir:

a) bandeja utilizando-se papel toalha (22 folhas) + "terra" (1 kg), com quatro niveis de capacidade de retenção de água do substrato: $60 \%, 70 \%, 80 \%$ e $90 \%$.

b) bandeja utilizando-se apenas "terra" $(2 \mathrm{~kg})$, com os mesmos níveis de retenção de água citados no item anterior.

Para esses dois tratamentos, e em todos os níveis de água, foram utilizadas 4 repetições de 50 sementes de apenas um lote de sementes de milho. Estes procedimentos foram conduzidos conforme o item 3.2 - a, mas as sementes não foram expostas ao período de frio.

\section{C) Uso de condições controladas de temperatura, umidade relativa e luz para a germinação das sementes}

Como a etapa 3.3 deste projeto seria conduzida em época do ano em que as temperaturas, em ambiente normal, geralmente são mais baixas (maio/junho), houve necessidade de controlar as condições de temperatura e umidade relativa do ambiente onde as sementes seriam colocadas para germinar. Para tanto, testes preliminares foram conduzidos utilizando-se câmaras de germinação do tipo M.A 401 e "Seedburo" (figura 04), reguladas a $25^{\circ} \mathrm{C}$ e com umidade relativa em torno de $100 \%$. Na câmara "Seedburo", apenas um de seus compartimentos foi iluminado durante o período de germinação das sementes. 


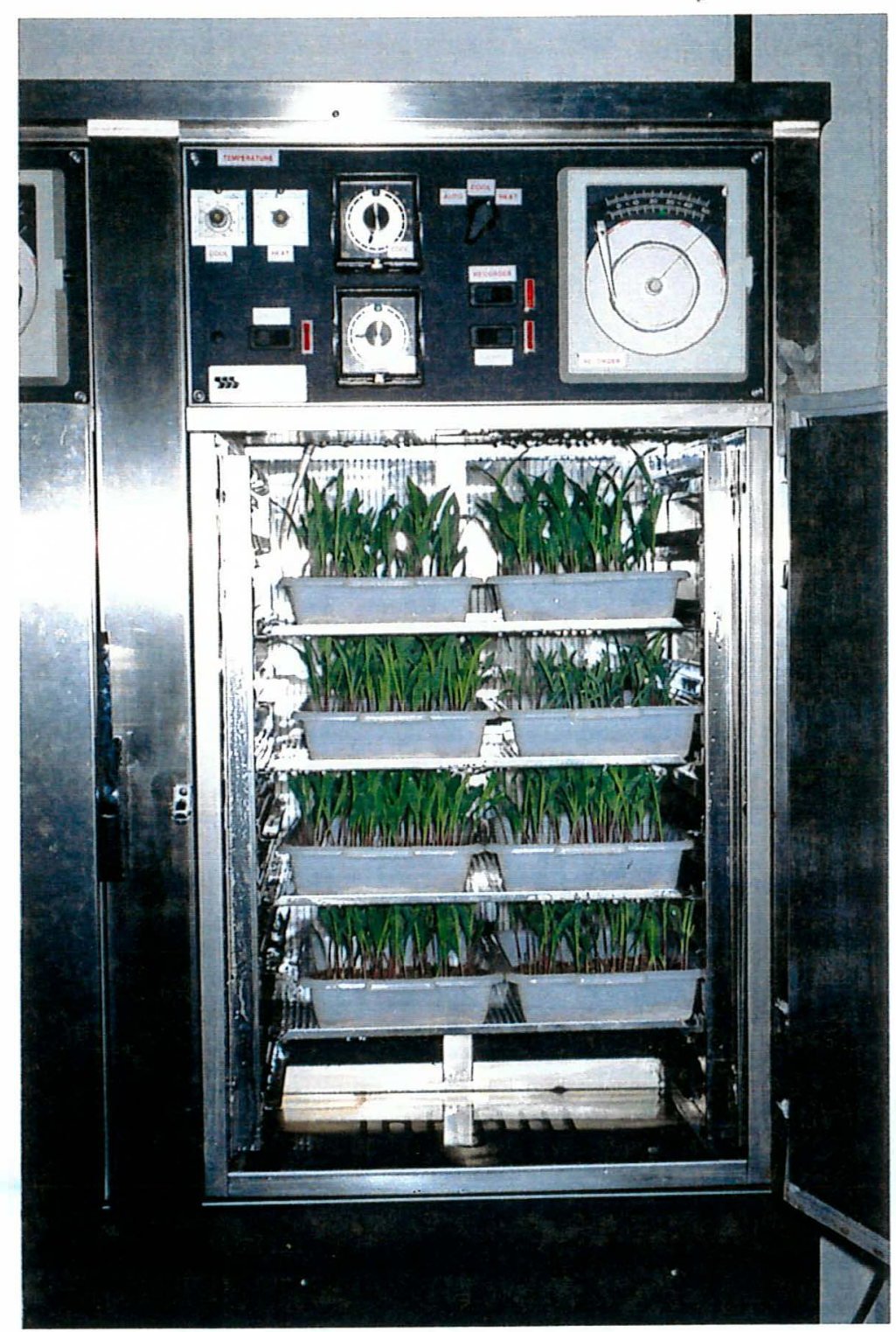

Figura 4. Câmara de germinação tipo "Seedburo", utilizada para fornecer condições controladas de temperatura e umidade relativa, durante o período de germinação das sementes no teste de frio. 
Os procedimentos adotados para esta avaliação foram os métodos de bandeja com "terra" ( $2 \mathrm{~kg}$ ) e bandeja com "terra" (1 kg) + papel (22 folhas), ambos ajustados para potenciais hídricos equivalentes a $70 \%$ e $80 \%$ de capacidade de retenção de água do substrato, considerados os melhores tratamentos dentre os pré-avaliados (item $3.2-b$ ). Estes procedimentos foram instalados conforme descrição encontrada no item $3.2-a$, mas as sementes não passaram pelo período de exposição ao frio.

Apenas um lote de sementes foi utilizado nessas avaliações. Uma bandeja representando cada tratamento ( 2 repetições de 50 sementes) foi colocada na câmara tipo M.A 401. Na câmara "Seedburo", foram colocados apenas os tratamentos com $70 \%$ da capacidade de retenção de água. A avaliação foi feita aos 5 e 7 dias após a instalação do teste, computando-se o número de plântulas normais de cada tratamento.

\subsection{Comparação do teste de frio com outros métodos para avaliação do potencial fisiológico}

Nesta etapa, foram realizados os seguintes testes: germinação, teste de frio "em caixas" (empilhadas e dispostas lado a lado), teste de frio "em bandeja" (bandeja com 'terra' e bandeja com 'terra' + papel toalha), envelhecimento acelerado, emergência das plântulas em campo e determinação do grau de umidade. Os testes foram repetidos duas vezes, com intervalo de 30 a 45 dias, para a verificação da precisão dos resultados. Para cada teste foram utilizadas 4 repetições de 50 sementes de cada lote. Utilizaram-se 4 cultivares de milho híbrido, cada um representado por 5 lotes com potencial fisiológico distinto.

\subsubsection{Germinação padrão}

O teste de germinação padrão foi conduzido de acordo com as Regras para Análise de Sementes (Brasil, 1992), com 4 repetições de 50 sementes 
para cada lote, distribuídas em rolos de papel toalha e colocadas para germinar a $25^{\circ} \mathrm{C}$. O volume de água utilizado para embebição foi equivalente a 2,5 vezes o peso do substrato. As contagens foram realizadas aos 4 e 7 dias após a semeadura.

\subsubsection{Teste de frio "em caixas"}

Nas avaliações preliminares diferenças marcantes foram detectadas entre o teste de frio "em caixas" empilhadas, com substrato e água a temperatura ambiente (método tradicional) e o teste de frio "em caixas" dispostas lado a lado, com substrato e água resfriados a $10^{\circ} \mathrm{C}$; este procedimento conduziu a menores variações entre os resultados. Portanto a temperatura do substrato e a disposição das caixas no interior da câmara fria, foram duas das variáveis avaliadas neste procedimento.

\subsubsection{Teste de frio "em caixas" empilhadas}

A caixa utilizada $(47 \times 30 \times 11 \mathrm{~cm})$ foi dividida em quatro compartimentos, cada um destinado à distribuição de 50 sementes. A obtenção do substrato, procedimentos para a distribuição das sementes e ajuste da disponibilidade de água do substrato, foram feitos da mesma forma descrita no item 3.1-a. O substrato e a água utilizados neste procedimento não foram pré-resfriados. As sementes avaliadas não receberam nenhum tipo de tratamento adicional, ou seja, apresentavam-se apenas com o tratamento feito pelas empresas que as produziram.

Ao serem colocadas na câmara fria, as caixas foram superpostas formando pilhas; cada pilha foi composta por 4 caixas. $O$ resfriamento foi conduzido a $10^{\circ} \mathrm{C}$, durante 7 dias e, em seguida, a germinação foi avaliada a 
$25^{\circ} \mathrm{C}$ durante 7 dias (na primeira época) e durante 8 dias (na segunda época), computando-se a porcentagem de plântulas normais para cada lote e cultivar.

\subsubsection{Teste de frio "em caixas" dispostas lado a lado}

Os procedimentos para a distribuição das sementes e ajuste da disponibilidade de água do substrato foram feitos da mesma forma descrita no ítem 3.1-a. Neste caso, a "terra" e a água foram pré-resfriadas a $10^{\circ} \mathrm{C} \mathrm{e}$, as caixas, dispostas lado a lado na câmara fria. $O$ resfriamento e a germinação foram conduzidos conforme item 3.3.2.1.

\subsubsection{Teste de frio em bandejas ("Tray method")}

Durante as avaliações preliminares, observou-se que os melhores procedimentos desta categoria foram os testes de frio em bandeja com "terra" ( $2 \mathrm{~kg}$ ) e bandeja com "terra" ( $1 \mathrm{~kg})+$ papel toalha (22 folhas), ambos com $70 \%$ de capacidade de retenção de água do substrato e com germinação conduzida em ambiente iluminado e controle de temperatura e umidade relativa. Portanto, esses dois procedimentos foram escolhidos para compor o conjunto de testes utilizados para a avaliação do potencial fisiológico das sementes de milho.

\subsubsection{Teste de frio em bandejas utilizando-se "terra" como substrato}

Foram utilizadas bandejas de plástico de $34 \times 23 \times 7 \mathrm{~cm}$, com $1 \mathrm{~kg}$ de "terra". Em cada bandeja foram distribuídas duas repetições de 50 sementes; em seguida, cobertas com $1 \mathrm{~kg}$ do mesmo substrato. A disponibilidade de água do substrato foi ajustada para $70 \%$ da sua capacidade de retenção. A água utilizada foi previamente resfriada a $10^{\circ} \mathrm{C}$. 
Para reduzir a evaporação, as bandejas foram protegidas com saco plástico e, em seguida, transferidas para câmara fria a $10^{\circ} \mathrm{C}$ por 7 dias. As bandejas foram colocadas em carrinhos adaptados, conforme descrito no item 3.2-a. Após o período de frio, as bandejas foram transferidas para germinadores (tipo M.A. 401 e "Seedburo"), em presença de luz e regulados a $25^{\circ} \mathrm{C}$, sendo as contagens realizadas aos 5 e 7 dias.

\subsubsection{Teste de frio em bandejas utilizando-se "terra" e papel toalha como substrato}

As bandejas utilizadas foram as mesmas descritas no item 3.3.3.1. No fundo da bandeja foram colocadas 22 folhas de papel toalha, umedecidas com quantidade de água equivalente a 2,5 vezes o seu peso. Em cada bandeja foram distribuídas 2 repetições de 50 sementes e, em seguida, essas foram cobertas com $1 \mathrm{~kg}$ de "terra". A disponibilidade de água do substrato, a temperatura e o período de frio e a germinação também corresponderam à descrição efetuada no item 3.3.3.1.

\subsubsection{Envelhecimento acelerado}

Para este procedimento foram utilizadas caixas plásticas adaptadas, funcionando como compartimentos individuais (mini-câmara). Em cada caixa plástica, foram colocados $40 \mathrm{ml}$ de água. As sementes foram distribuídas uniformemente sobre tela de alumínio, colocada no interior de cada caixa, formando uma camada única. As caixas plásticas foram tampadas e mantidas em câmara de envelhecimento (tipo B.O.D) regulada à $41^{\circ} \mathrm{C}\left( \pm 0,3^{\circ} \mathrm{C}\right)$, onde permaneceram por 96 horas (AOSA, 1983). Após esse período, as sementes foram colocadas para germinar a $25^{\circ} \mathrm{C}$ e avaliadas aos 4 dias após a 
semeadura. Os resultados foram expressos em porcentagem de plântulas normais para cada lote e cultivar.

Avaliações do grau de umidade (método da estufa, a $105^{\circ} \mathrm{C} \pm 3^{\circ} \mathrm{C}$ por 24 horas), antes e após o período de envelhecimento, permitiram verificar a precisão dos resultados.

\subsubsection{Grau de umidade}

A determinação do grau de umidade foi efetuada de acordo com as Regras para Análise de Sementes (Brasil, 1992), utilizando-se o método da estufa a $105^{\circ} \mathrm{C} \pm 3^{\circ} \mathrm{C}$ por 24 horas, com duas repetições para cada lote.

\subsubsection{Emergência das plântulas em campo}

Avaliação conduzida mediante delineamento blocos ao acaso, com 4 repetições para cada lote. Cada repetição foi composta por uma linha de $4 \mathrm{~m}$ de comprimento, onde foram distribuidas 50 sementes, espaçadas entre si de $8 \mathrm{~cm}$, em sulcos com cerca de $7 \mathrm{~cm}$ de profundidade e cobertas com, aproximadamente, $3 \mathrm{~cm}$ de terra. O espaçamento entre linhas foi de $40 \mathrm{~cm}$. Aos 14 dias após a semeadura, foi efetuada a contagem, e os resultados foram expressos em percentagem de plântulas normais.

\subsubsection{Procedimento estatístico}

Para os testes realizados em laboratório, correspondentes ao item 3.3, a análise estatística foi efetuada utilizando-se $\circ$ delineamento experimental inteiramente casualizado, com 5 tratamentos (lotes com diferentes niveis de 
vigor) e 4 repetições, para cada observação ou teste conduzido. Cada cultivar foi analisado separadamente.

O esquema da análise da variância é apresentado a seguir:

\begin{tabular}{lc}
\hline CAUSAS DA VARIAÇĀO & G. L \\
LOTES & 4 \\
RESÍDUO & 15 \\
\hline TOTAL & 19 \\
\hline
\end{tabular}

Para o teste de emergência das plântulas em campo, foi adotado o delineamento blocos ao acaso, com 5 tratamentos (lotes com diferentes niveis de vigor) e 4 repetições. Cada cultivar foi analisado separadamente.

O esquema da análise da variância é apresentado a seguir:

\begin{tabular}{lc}
\hline CAUSAS DA VARIAÇĂO & G. L \\
\hline LOTES & 4 \\
BLOCOS & 3 \\
RESÍDUO & 12 \\
TOTAL & 19 \\
\hline
\end{tabular}

Para todos os testes foram feitas análises de variância e, a comparação de médias, realizada através do Teste de Tukey ao nível de $5 \%$ de probabilidade. 


\section{RESULTADOS E DISCUSSÃO}

\subsection{Observações preliminares sobre o teste de frio em caixas}

O método de "terra" em caixa é de difícil padronização, pois requer o uso de maior quantidade de substrato quando comparado com outros métodos. Neste caso, podem surgir problemas com a distribuição desuniforme de água no substrato, com o tempo necessário para o substrato atingir a temperatura desejada $\left(10^{\circ} \mathrm{C}\right)$ e também com $\circ$ manuseio das caixas, visto que estas apresentam peso relativamente elevado. Outra preocupação com o método refere-se à disposição das caixas no interior da câmara fria; geralmente as caixas são superpostas formando pilhas e, desta forma, o resfriamento do substrato pode não ocorrer de maneira uniforme entre as caixas. Tais fatores podem influenciar a germinação das sementes no teste de frio, colocando em dúvida a confiabilidade e reprodutibilidade do procedimento.

Portanto, observações preliminares foram feitas para verificar se o préresfriamento do substrato e a disposição das caixas no interior da câmara fria, poderiam fornecer condições de maior uniformidade ao teste.

Os resultados referentes à temperatura do substrato e à porcentagem de plântulas normais, após o resfriamento, obtidos durante o estudo sobre préresfriamento do substrato e disposição das caixas no interior da câmara fria, encontram-se nas figuras $5,6,7,8,9$ e 10 .

Como o substrato de todos os tratamentos não havia atingido $10^{\circ} \mathrm{C}$ após 8 horas de avaliação, a temperatura foi determinada novamente após 26 horas, para verificar se já havia atingido $10^{\circ} \mathrm{C}$ e também para detectar possíveis variações dos resultados. 
Durante as primeiras horas de resfriamento, verificou-se estratificação de temperatura do substrato, tanto nos tratamentos em que o umedecimento foi realizado com água à temperatura ambiente (figura 5) como pré-resfriada a $10^{\circ} \mathrm{C}$ (figura 6 ), ambos em caixas empilhadas. Estes dois tratamentos, também apresentaram diferenças acentuadas na porcentagem de plântulas normais, entre as 4 caixas da pilha. As duas caixas intermediárias, apresentaram temperatura mais elevada que as situadas na parte superior e na mais próxima do piso. Após 6 horas de resfriamento, a temperatura das caixas 2,3 e 4, tenderam a se uniformizar, mas a caixa 1 manteve-se com a temperatura mais baixa.

Posteriormente, nas avaliações realizadas as 8, 26 e 168 horas após a instalação do teste, diferenças mais amplas de temperatura do substrato, foram verificadas entre as caixas 1 e 4 , permanecendo esta última com a temperatura ligeiramente mais elevada. Tal fato, também foi observado no tratamento de substrato e água resfriados a $10^{\circ} \mathrm{C}$ em caixas empilhadas (figura 7 ).

Como o ar frio circula livremente pelas laterais e, também, pela superfície das caixas posicionadas na parte superior da pilha, o resfriamento do substrato ocorre de forma mais rápida. Nas caixas de posição intermediária e inferior, o resfriamento já ocorre mais lentamente. Provavelmente, a caixa situada na parte superior (caixa1) pode atuar como barreira, dificultando a passagem de ar através do substrato. Portanto, o resfriamento das caixas intermediárias e da caixa inferior ocorre principalmente a partir das faces laterais de cada uma delas.

Apesar de haver redução da circulação de ar na superfície do substrato da caixa inferior, o resfriamento ocorre mais rapidamente em relação às caixas intermediárias. Isso talvez possa ser explicado, pelo fato de que o ar frio tende a se acumular próximo ao piso. De toda forma, esse efeito parece mais pronunciado durante as primeiras horas de resfriamento, visto que posteriormente, o substrato da caixa inferior manteve temperatura semelhante às das demais caixas. 


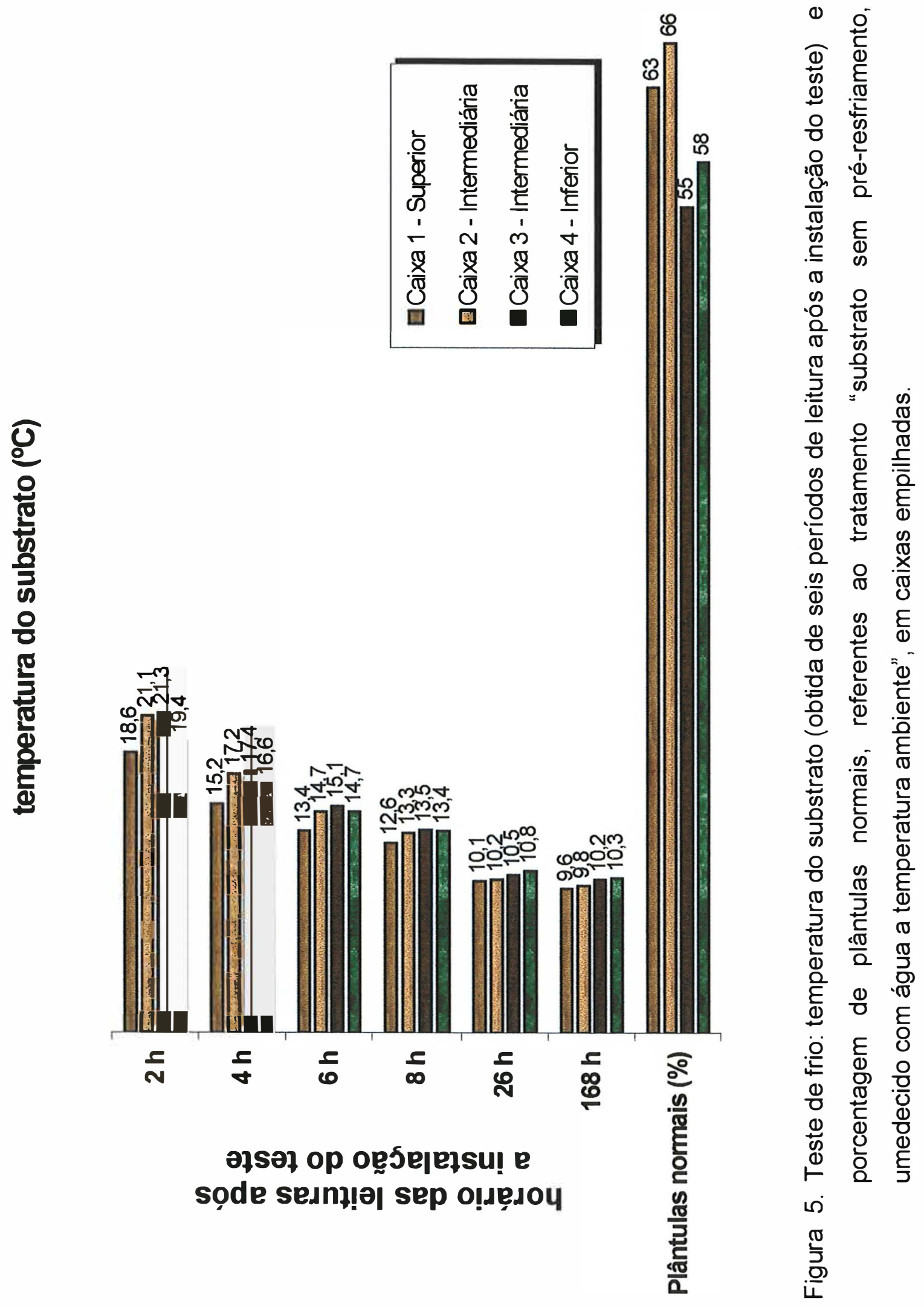




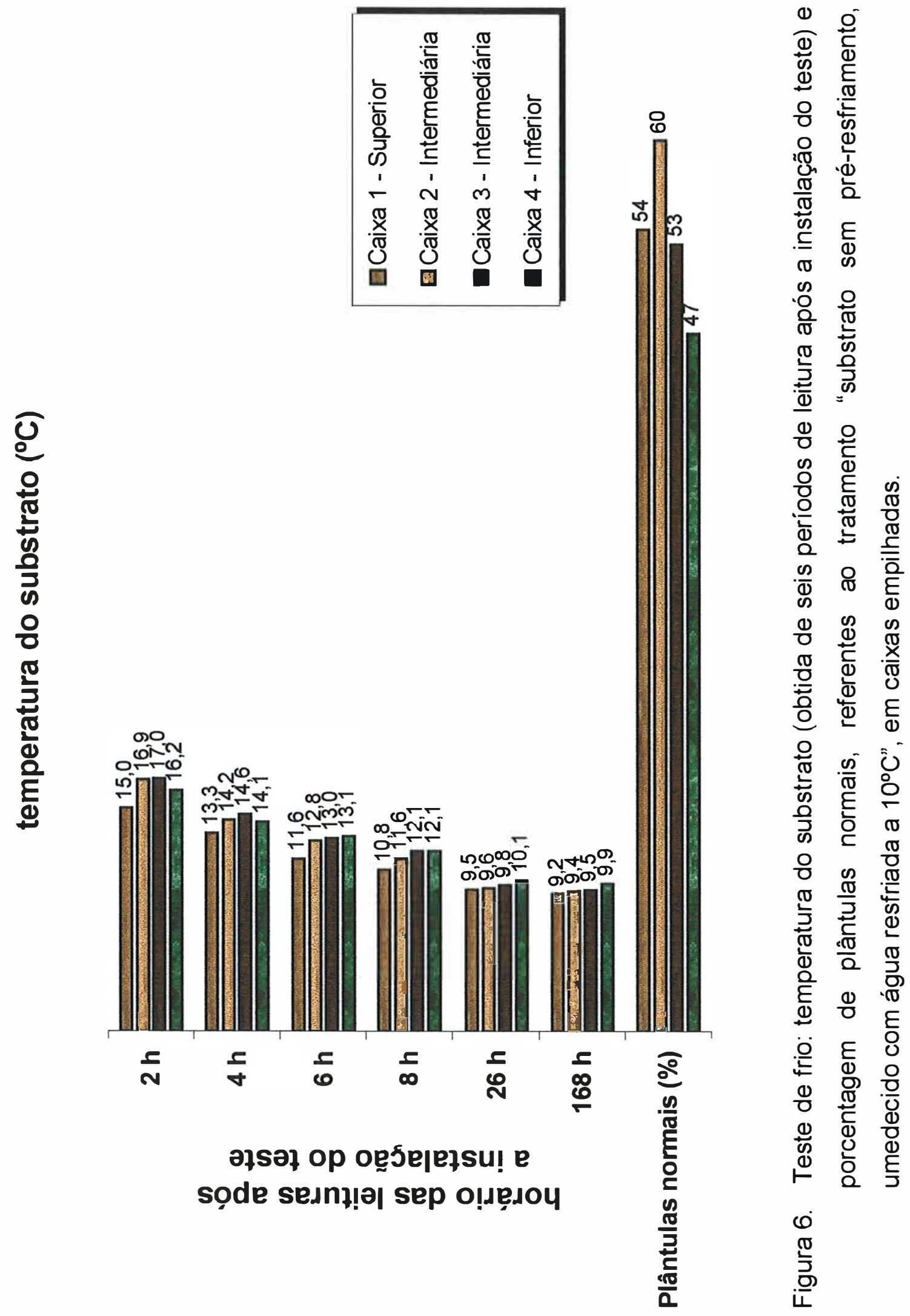







No tratamento "substrato e água resfriados a $10^{\circ} \mathrm{C}$ ", em caixas empilhadas (figura 7), verificou-se estratificação menos acentuada da temperatura; novamente, apenas o substrato da caixa 1 apresentou-se com temperatura mais baixa. Neste caso, entre as 4 caixas, o resfriamento do substrato e também a porcentagem de plântulas normais, foram mais uniformes quando comparados aos outros dois tratamentos que permaneceram em caixas empilhadas (figuras 5 e 6). Observou-se, também, resfriamento mais rápido do substrato.

Quando os tratamentos "substrato sem pré-resfriamento, umedecido com água à temperatura ambiente" (figura 8), "substrato sem pré-resfriamento, umedecido com água pré-resfriada a $10^{\circ} \mathrm{C}$ " (figura 9) e "substrato e água préresfriados a $10^{\circ} \mathrm{C}$ " (figura 10 ), foram dispostos lado a lado, não houve variações acentuadas de temperatura do substrato entre as caixas; o teste também tornou-se mais drástico, o que pôde ser observado pela redução na porcentagem de plântulas normais para todos os tratamentos. Nos dois primeiros casos, o resfriamento do substrato ocorreu de maneira uniforme e mais rapidamente, quando comparado com os mesmos tratamentos em caixas empilhadas. Porém, neste caso, também houve variações na porcentagem de plântulas normais entre as caixas do mesmo tratamento. Já, para o tratamento "substrato e água pré-resfriados a $10^{\circ} \mathrm{C}$ " em caixas dispostas lado a lado, apesar da maior uniformidade de temperatura do substrato e da porcentagem de plântulas normais, notou-se praticamente a mesma velocidade de resfriamento, quando comparado com o mesmo tratamento em caixas empilhadas.

Em todos os tratamentos realizados, não foi possivel detectar exatamente qual o período necessário para o substrato atingir $10^{\circ} \mathrm{C}$. Estima-se que esse equilíbrio com a temperatura da câmara fria, deva ter ocorrido aproximadamente 10 horas após a instalação do teste, com exceção para o tratamento "substrato sem pré-resfriamento, umedecido com água a 


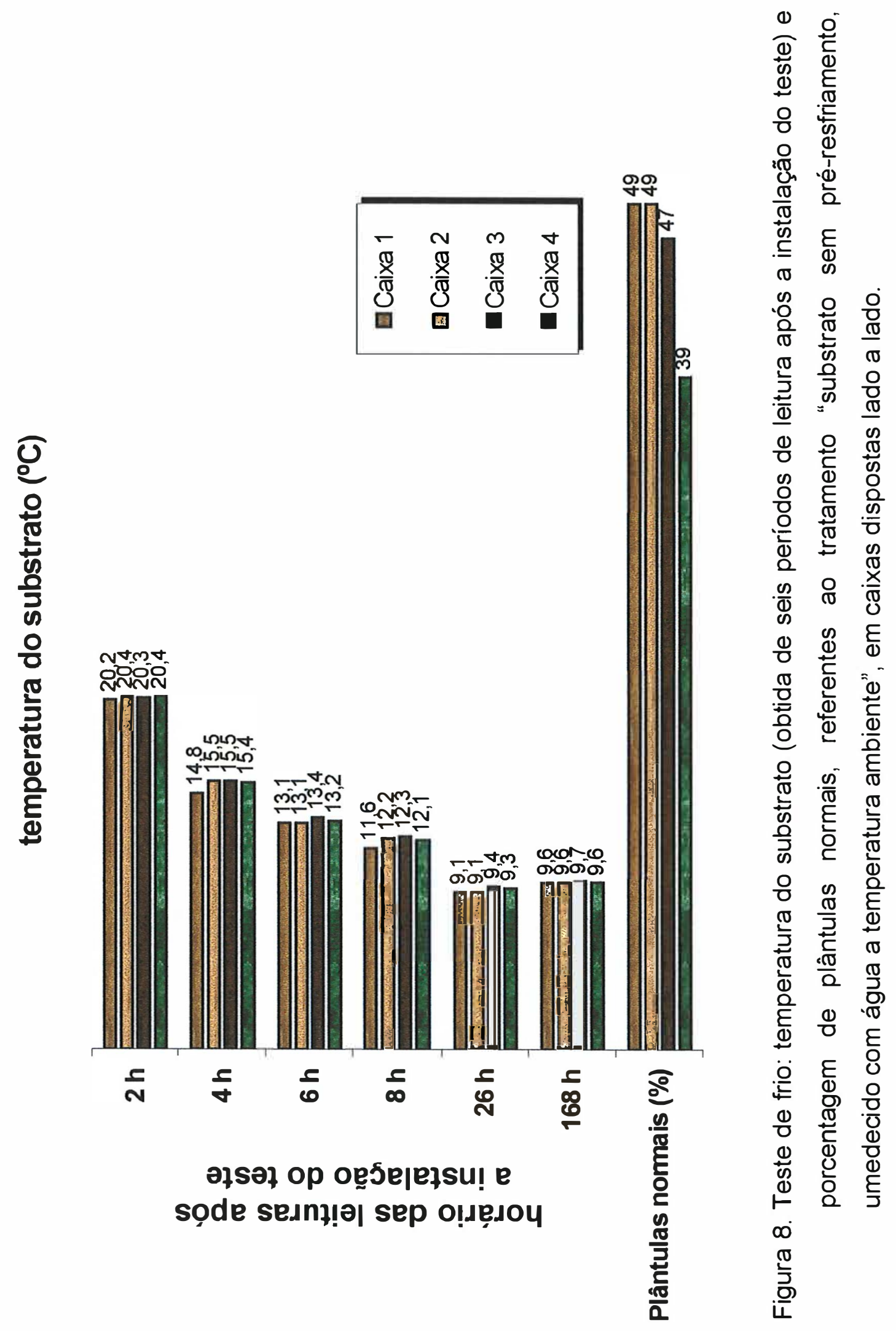




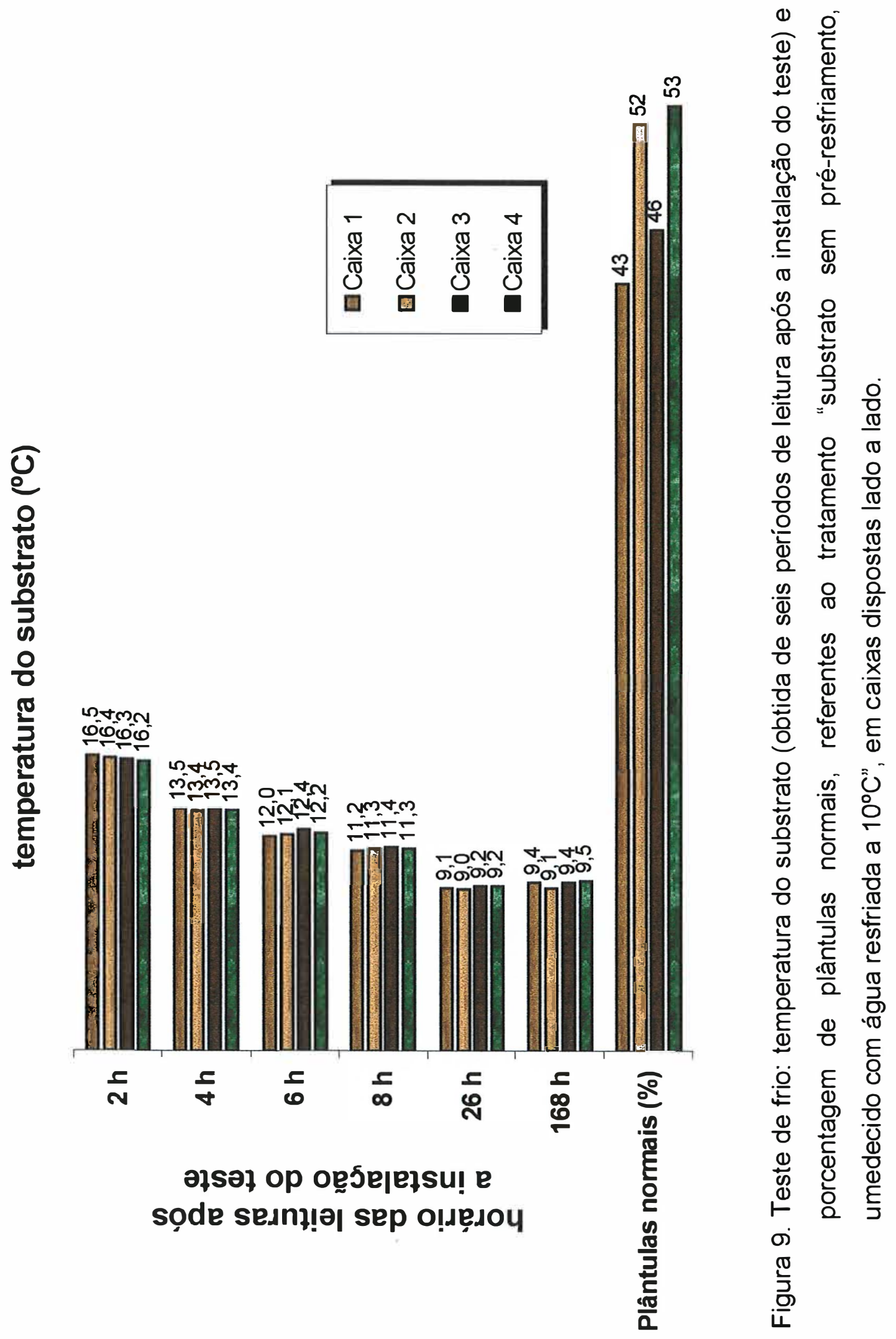




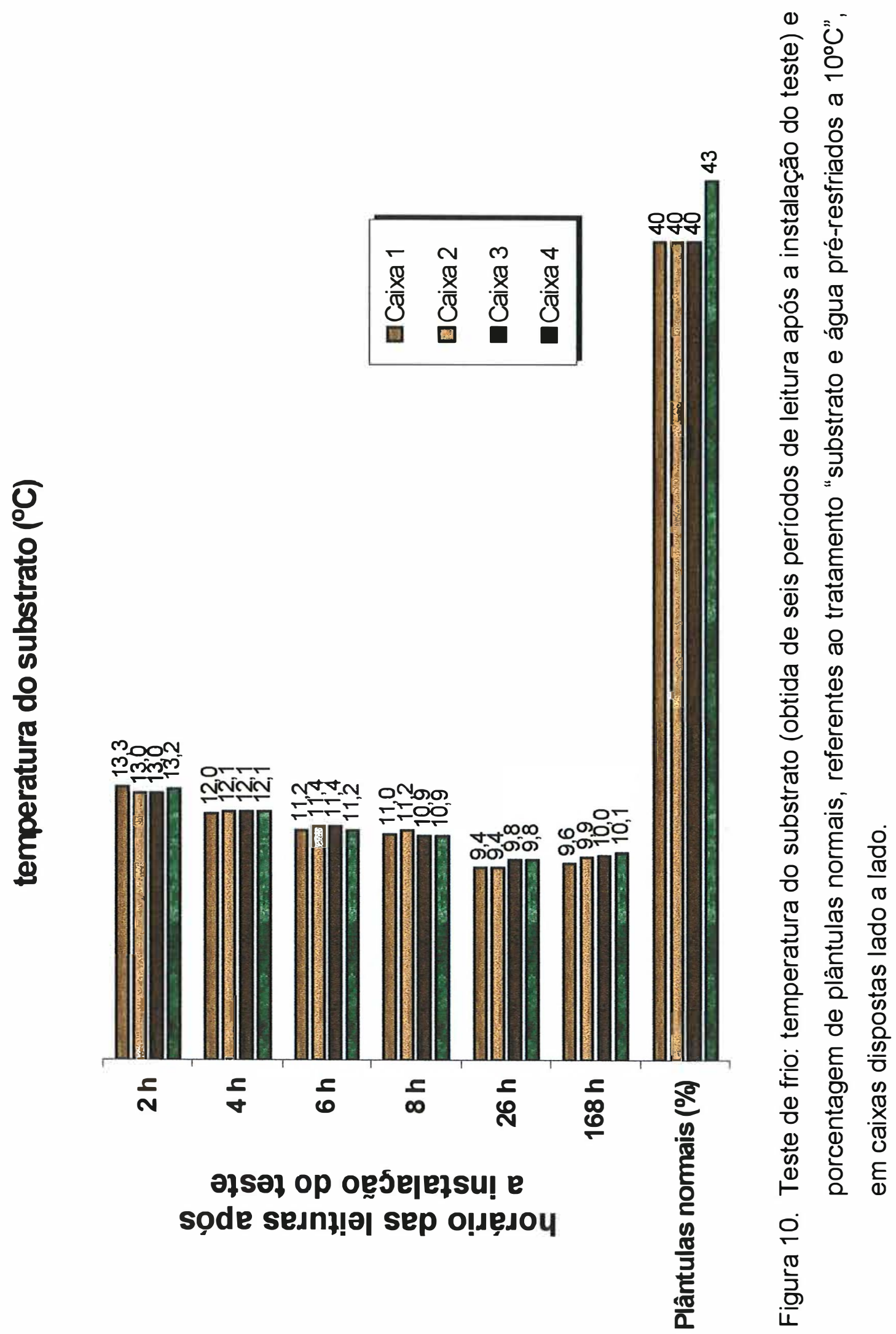


temperatura ambiente", em caixas empilhadas que, após 26 horas da instalação, ainda não havia atingido $10^{\circ} \mathrm{C}$.

Como o resfriamento do substrato não ocorreu de maneira uniforme no sistema de caixas empilhadas, diferentes condições de temperatura foram proporcionadas às sementes durante o período de embebição. Outro ponto a ser destacado, é que a fase de embebição ocorreu sob temperaturas mais elevadas. Tal fato, pode se constituir em mais um fator de influência nos resultados do teste de frio.

Temperaturas relativamente baixas durante os estágios iniciais de embebição, são mais críticas para causar injúrias por resfriamento (Woodstock e Pollock, 1965; Pollock e Toole, 1966; Christiansen, 1968; Cal e Obendorf, 1972). Quando a embebição ocorre a temperaturas favoráveis (em torno de $25^{\circ} \mathrm{C}$ ), as sementes ficam menos sensiveis aos danos causados pelo frio, mesmo que depois sejam expostas a baixas temperaturas. Woodstock e Pollock (1965) verificaram que temperaturas de $15^{\circ} \mathrm{C}$ ou inferiores, durante as primeiras horas de embebição, inibem o posterior crescimento das plântulas de feijão lima (Phaseolus lunatus L.). Cal e Obendorf (1972) destacaram que a injúria pode ocorrer durante a embebição, porém é mais pronunciada com o prolongamento do periodo de frio.

Por ter apresentado maior uniformidade na porcentagem de plântulas normais e também de temperatura durante o resfriamento do substrato, 0 tratamento "substrato e água pré-resfriados a $10^{\circ} \mathrm{C}$ ", em caixas dispostas lado a lado, foi um dos métodos escolhidos para compor o conjunto de testes realizados na etapa seguinte da pesquisa. O outro método selecionado, foi o tratamento "substrato sem pré-resfriamento, umedecido com água a temperatura ambiente", em caixas empilhadas. Este, não mostrou ser o melhor procedimento, visto que apresentou estratificação de temperatura durante o resfriamento do substrato e, também, maior desuniformidade na porcentagem de plântulas normais. Entretanto, sua comparação com outros procedimentos se faz necessária, pois é considerado método tradicional no Brasil, sendo o 
mais utilizado pelas empresas, instituições e/ou universidades que adotam 0 teste de frio para a avaliação do potencial fisiológico das sementes.

\subsection{Observações preliminares sobre o teste de frio em bandejas}

\section{A) Estudo do tipo e quantidade do substrato a ser utilizado}

Como o método da bandeja envolve o uso de papel "Kimpak" (ou similar) para a semeadura, a quantidade de "terra" utilizada deve ser suficiente apenas para a cobertura das sementes. Neste caso, a "terra" está presente mais para fornecer uma fonte de inóculo ao teste (Hampton e TeKrony, 1995). Nesta etapa, além da combinação de folhas de papel toalha e "terra", foi avaliada, também, a possibilidade de se utilizar apenas "terra" como substrato para o método da bandeja.

Em função da menor quantidade de "terra", este procedimento pode oferecer maior grau de controle das condições de umidade e temperatura do substrato, facilitando a padronização do teste.

Os dados referentes ao potencial fisiológico de dois lotes de sementes após 0 teste de frio, submetidas aos tratamentos de 6 folhas de papel toalha +1 $\mathrm{kg}$ de "terra", 12 folhas de papel toalha $+1 \mathrm{~kg}$ de "terra" e utilização de apenas "terra" $(2 \mathrm{~kg})$ como substrato, encontram-se na tabela 1.

Embora a posição dos lotes, quanto ao potencial fisiológico, tenha sido semelhante nos três tratamentos, as sementes mostraram melhor desempenho quando utilizou-se apenas "terra" como substrato. Neste tratamento, a quantidade de água foi suficiente para a germinação e desenvolvimento das plântulas e, após 4 ou 5 dias de exposição à temperatura ambiente, já era possivel fazer a avaliação da germinação. No $7^{\circ}$ dia de exposição à temperatura ambiente, as plântulas mostravam sintomas nítidos de deficiência hídrica, pois houve maior evaporação da água do substrato em relação ao $5^{\circ}$ dia. No teste 
de frio utilizando-se "terra" em caixa, essa evaporação não é tão drástica para as plântulas, pois há maior quantidade de "terra" e, consequentemente, maior disponibilidade de água.

Tabela 1 Potencial fisiológico após o teste de frio, de dois lotes de sementes submetidos ao tratamento de bandejas com 6 folhas de papel toalha + $1 \mathrm{~kg}$ de "terra", bandejas com 12 folhas + 1kg de "terra" e bandejas contendo apenas "terra" como substrato.

Plântulas Normais (\%)

Tratamentos

Lote A

86

91

94

\section{Lote B}

60

80

72

Apenas "terra" $(2 \mathrm{~kg})$

Quando utilizaram-se 12 folhas de papel toalha + $1 \mathrm{~kg}$ de "terra", o potencial fisiológico foi semelhante ao tratamento envolvendo apenas "terra", mas a quantidade de água não foi suficiente para um crescimento adequado das plântulas; estas, encontravam-se pouco desenvolvidas no momento da avaliação, quando comparadas com o tratamento de bandejas utilizando-se apenas "terra" como substrato.

Com relação ao tratamento de 6 folhas de papel toalha + 1 kg de "terra", não houve água suficiente para o desenvolvimento das plântulas até o momento da avaliação. As sementes chegaram a germinar, mas as plântulas pouco cresceram $(<2 \mathrm{~cm})$ e a folha primária não chegou a romper o coleóptilo. 
Os dados referentes à temperatura do substrato, dos mesmos tratamentos citados, verificada após 1 e 2 horas da instalação do teste de frio, são apresentados a seguir:

Tabela 2 Dados referentes à temperatura do substrato, verificada 1 e 2 horas após a instalação do teste de frio, de três tratamentos envolvendo a semeadura em bandejas.

\begin{tabular}{|c|c|c|c|c|}
\hline \multirow{3}{*}{ Tratamentos } & \multicolumn{4}{|c|}{ Temperatura do substrato $\left({ }^{\circ} \mathrm{C}\right)$} \\
\hline & \multicolumn{2}{|c|}{ Após 1 hora* } & \multicolumn{2}{|c|}{ Após 2 horas* } \\
\hline & Parte superior ${ }^{\star \star}$ & Parte inferior ${ }^{\star \star}$ & Parte superior ${ }^{\star \star}$ & Parte inferior ${ }^{* *}$ \\
\hline $\begin{array}{l}6 \text { folhas }+1 \mathrm{~kg} \text { de } \\
\text { "terra" }\end{array}$ & 8,1 & 9,5 & 7,2 & 8,5 \\
\hline $\begin{array}{l}12 \text { folhas }+1 \mathrm{~kg} \text { de } \\
\text { "terra" }\end{array}$ & 8,3 & 9,8 & 7,6 & 8,2 \\
\hline $\begin{array}{l}\text { Apenas "terra" } \\
(2 \mathrm{~kg})\end{array}$ & 10,6 & 10,8 & 8,5 & 8,8 \\
\hline
\end{tabular}

A temperatura de $10^{\circ} \mathrm{C}$ (ou menor) foi atingida após 1 hora da instalação do teste, para os tratamentos de 6 e 12 folhas de papel toalha $+1 \mathrm{~kg}$ de "terra" e, após 2 horas, para o tratamento que utiliza apenas "terra" como substrato.

As bandejas situadas na parte superior do carrinho adaptado, apresentaram um resfriamento mais rápido do substrato, quando comparadas com as situadas na parte inferior, principalmente para os tratamentos envolvendo folhas de papel toalha + "terra" como substrato. Quando utilizou-se apenas "terra", o resfriamento foi mais uniforme entre as bandejas da parte 
superior e inferior do carrinho. É importante ressaltar que, neste procedimento, o resfriamento do substrato ocorreu mais rapidamente que o método de "terra" em caixa.

Como os tratamentos de 6 e 12 folhas de papel toalha não ofereceram quantidade de água suficiente para um desenvolvimento adequado das plântulas, um quarto tratamento foi avaliado, mantendo a quantidade de "terra" e aumentando para 22 o número de folhas de papel toalha. $O$ tratamento bandejas utilizando-se apenas "terra" $(2 \mathrm{~kg})$ foi instalado novamente para efeito comparativo.

Os dados referentes ao potencial fisiológico de amostras de dois lotes de sementes de milho, após o teste de frio, expostas ao tratamento bandejas com 22 folhas de papel toalha + $1 \mathrm{~kg}$ de "terra" e bandejas contendo apenas "terra" como substrato, são apresentados a seguir:

Tabela 3 Potencial fisiológico após o teste de frio, de amostras de dois lotes de sementes submetidas ao tratamento bandejas com 22 folhas de papel toalha + $1 \mathrm{~kg}$ de "terra" e bandejas contendo apenas "terra" como substrato.

\begin{tabular}{ccc}
\hline & \multicolumn{3}{c}{ Tratamentos } \\
\cline { 2 - 3 } Lotes & 22 folhas com $1 \mathrm{~kg}$ de "terra" & Apenas "terra" (2kg) \\
\hline A & 90 & 92 \\
B & 87 & 90 \\
\hline
\end{tabular}

Com base nos dados da tabela 3 , observa-se que tanto o lote $A$, como lote $\mathrm{B}$, apresentaram potencial de desempenho semelhante.

No $5^{\circ}$ dia após a exposição das sementes a temperatura ambiente, as plântulas de ambos tratamentos ainda estavam túrgidas e já era possível fazer 
com segurança a contagem de plântulas normais, embora esta tenha sido realizada apenas no $6^{\circ}$ dia. A umidade relativa do ambiente manteve-se entre $83 \%$ a $99 \%$ até o $4^{\circ}$ dia; posteriormente, esta passou a decrescer, atingindo 60 a $70 \%$ no dia da avaliação das plântulas. Tal fato, provocou maiores perdas de água do substrato, principalmente no tratamento bandejas utilizando-se apenas "terra", o qual apresentava-se com as plântulas murchas e tombadas.

A umidade relativa do ambiente exerce influência direta na manutenção de água do substrato durante o período de germinação das sementes no teste de frio, principalmente quando se utilizam menores quantidades de terra, como é o caso do método em bandejas. Com $60 \%$ da capacidade de retenção de água do substrato, a germinação ocorre normalmente e também há desenvolvimento de plântulas, desde que a umidade relativa do ambiente se mantenha acima de $83 \%$. Abaixo desse valor, o desempenho das plântulas no teste de frio em bandejas, pode ficar comprometido.

\section{B) Estudo da capacidade de retenção de água do substrato}

Nesta etapa, o objetivo foi verificar se a manutenção de níveis mais altos de capacidade de retenção de água, permitiria conservar a umidade do substrato durante maior período (em ambiente não controlado de temperatura e umidade relativa), sem prejudicar a germinação. Os dados referentes às porcentagens de germinação das sementes em substratos com 60, 70, 80 e 90\% da capacidade de retenção de água, encontram-se na tabela 4 .

Em função de queda da temperatura ambiente, houve atraso da germinação das sementes e a avaliação deste procedimento somente foi realizada aos 8 dias.

Com relação à evaporação da água do substrato, o tratamento mais sensivel foi o correspondente a bandejas contendo folhas de papel toalha e "terra", com $60 \%$ da capacidade de retenção de água; as plântulas apresentavam-se menos desenvolvidas quando comparadas com plântulas de 
outros tratamentos. Neste caso, houve inversão do que foi observado na etapa anterior, onde o tratamento bandejas com folhas de papel tolha e "terra", foi o que melhor reteve a umidade do substrato.

Tabela 4 Porcentagem de germinação de uma amostra de sementes, em substratos com 60, 70, 80 e 90\% da capacidade de retenção de água.

Capacidade de retenção de água do substrato (\%)

Tipos de substrato

\begin{tabular}{llll}
\hline 60 & 70 & 80 & 90 \\
\hline
\end{tabular}

Plântulas Normais (\%)

22 folhas de papel toalha +

91

88

93

90

$1 \mathrm{~kg}$ de "terra"

Apenas "terra" (2kg)

96

95

97

85

No momento da avaliação, substratos com $90 \%$ da capacidade de retenção, apresentavam-se com quantidade de água ainda elevada, principalmente em bandejas contendo apenas "terra" como substrato, onde foi constatada a menor porcentagem de germinação (85\%). Segundo Woltz et al.,(1998) a umidade do substrato no teste de frio, deve ser suficientemente alta para permitir a germinação e crescimento das plântulas, sem que ocorram condições anaeróbicas.

De um modo geral, todos os tratamentos que utilizaram apenas "terra", conservaram a umidade do substrato por maior periodo, quando comparados com os tratamentos envolvendo folhas de papel toalha e "terra". Nos dois casos, os melhores ajustes da disponibilidade de água do substrato, foram para 70 e $80 \%$ da capacidade de retenção de água. Estes forneceram quantidade de 
água suficiente para germinação e desenvolvimento das plântulas, sem apresentar secagem excessiva do substrato até o final do teste. Neste caso, a umidade relativa diária do ambiente, se manteve em torno de 60 a 100\%.

\section{c) Uso de condições controladas de temperatura, umidade relativa e luz para germinação das sementes}

$\mathrm{Na}$ tabela 5 encontram-se os dados referentes à porcentagem de germinação das sementes, em condições controladas de temperatura, umidade relativa e luz, utilizando-se os procedimentos bandejas com folhas de papel toalha + "terra" e apenas "terra", ambos com 70 e $80 \%$ da capacidade de retenção de água do substrato.

Tanto em bandejas com folhas de papel toalha + "terra", como em bandejas contendo apenas "terra", a germinação das sementes em substrato com $80 \%$ da capacidade de retenção de água, foi mais baixa e o desenvolvimento das plântulas mais desuniforme, quando comparados aos demais tratamentos.

O fator luz parece não ter influenciado a porcentagem total de germinação das sementes, mas provocou alterações no desenvolvimento das plântulas. Na ausência de luz, houve estiolamento e tombamento das plântulas (Figura 11), o que acabou dificultando a avaliação. Em ambiente iluminado, o crescimento das plântulas foi mais favorável (não houve estiolamento), possibilitando uma avaliação mais adequada e segura da porcentagem de germinação.

Com base nas informações obtidas durante as avaliações preliminares sobre o teste de frio em bandejas, observou-se que os melhores procedimentos desta categoria foram os testes de frio em bandeja com "terra" ( $2 \mathrm{~kg}$ ) e bandeja com "terra" ( $1 \mathrm{~kg}$ ) + papel toalha (22 folhas), ambos com $70 \%$ da capacidade de retenção de água do substrato, e germinação conduzida em ambiente iluminado 
e com controle de temperatura e umidade relativa. Portanto, esses dois métodos foram escolhidos para compor o conjunto de testes utilizados na etapa seguinte desta pesquisa, referente à comparação de métodos para avaliação do potencial fisiológico de sementes de milho.

Tabela 5 Porcentagem de germinação das sementes após 5 e 7 dias, em condições controladas de temperatura, umidade relativa e luz, utilizando-se os procedimentos bandejas com folhas de papel toalha + "terra" e apenas "terra", ambos com 70 e $80 \%$ da capacidade de retenção de água do substrato.

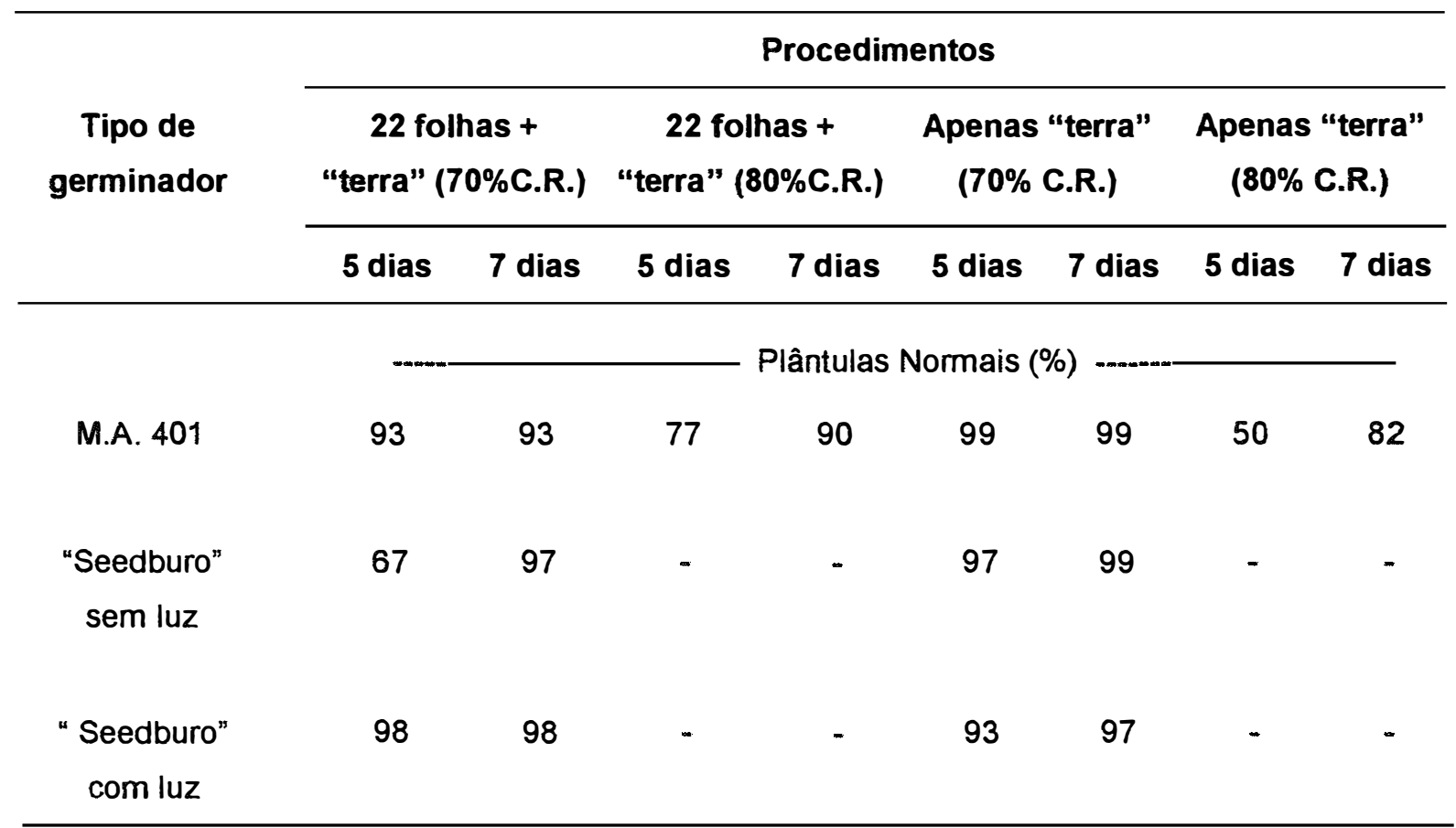




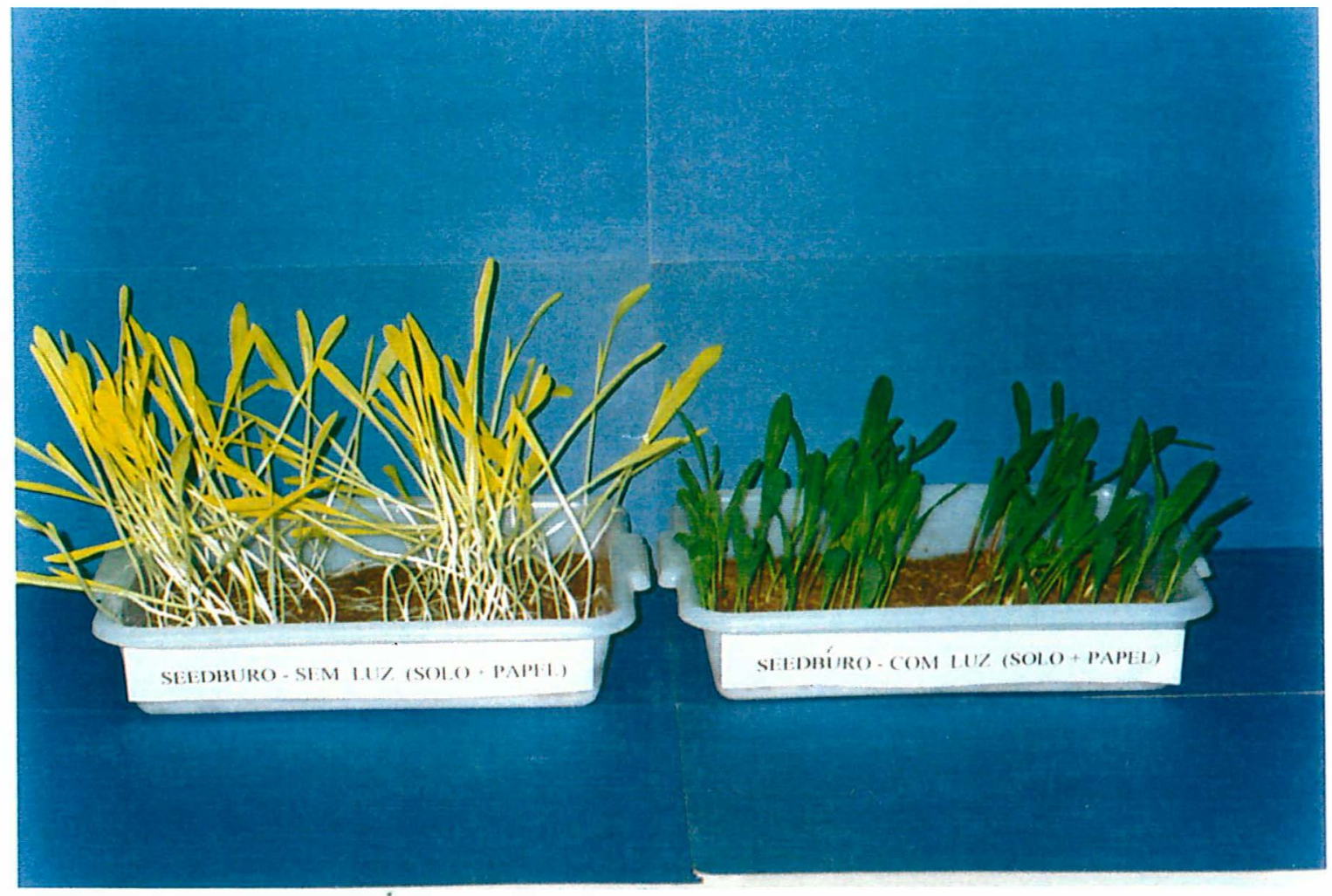

Figura 11. Aspecto das plântulas de milho desenvolvidas na ausência de luz (lado esquerdo) e em ambiente iluminado (lado direito). 


\subsection{Comparação do teste de frio com outros métodos para avaliação do potencial fisiológico}

Existem vários métodos disponíveis para avaliação do potencial fisiológico das sementes, mas nem todos apresentam a sensibilidade desejada para distinguir lotes de sementes com diferentes níveis de vigor. Portanto, esta etapa foi conduzida com o objetivo de comparar a eficiência de quatro procedimentos utilizados para a condução do teste de frio, selecionados com base em resultados das avaliações preliminares, com outros métodos utilizados para a avaliação do potencial fisiológico das sementes de milho.

O genótipo pode influenciar o comportamento fisiológico da semente e, consequentemente, interferir na classificação dos lotes em diferentes níveis de qualidade fisiológica (Marcos Filho, 1999). Cultivares distintos podem apresentar diferenças quanto a resistência a altas ou baixas temperaturas, ao ataque de patógenos e outros fatores que podem influenciar os resultados. Portanto, para esta pesquisa, foram utilizados 4 cultivares de milho (AG 122, AG 3010, AG 5011, AG 6018), cada um representado por 5 lotes com potencial fisiológico distinto, sendo que cada cultivar foi analisado separadamente.

Em função da camada menos espessa de "terra" e também das condições controladas de temperatura e umidade relativa, em que as sementes ficaram expostas no período de germinação, quando utilizou-se o teste de frio em bandejas, houve maior velocidade de germinação das sementes e desenvolvimento das plântulas, possibilitando que a avaliação fosse feita já aos 5 dias.

Portanto, para efeito comparativo, tanto na primeira, como na segunda época, as contagens de plântulas normais do teste de frio em bandejas, foram realizadas aos 5 e 7 dias. Como a classificação de lotes foi similar em ambas as avaliações, os dados apresentados referem-se apenas a contagem realizada aos 5 dias. Essa opção favoreceu a redução do período de avaliação das plântulas no teste de frio, proporcionando maior rapidez na obtenção dos 
resultados quando comparado com teste de frio utilizando-se "terra" em caixa. Embora a AOSA (1983), Burris (1990) e Hampton e TeKrony (1995) recomendem a contagem de plântulas normais aos 4 dias para o teste de frio em bandejas, Cícero e Vieira (1994) destacam que a avaliação realizada aos 5 dias parece conduzir à obtenção de resultados mais consistentes. .

O teste de frio utilizando-se "terra" em caixas, não foi conduzido em ambiente controlado de temperatura e umidade relativa, durante o período de germinação das sementes. Na primeira época, as condiçōes de temperatura eram ideais (em torno de $25^{\circ} \mathrm{C}$ ) e a avaliação pôde ser realizada aos 7 dias, conforme Marcos Filho et al (1987) e Dias e Barros (1995). Na segunda época, durante o período de germinação das sementes, houve queda da temperatura ambiente; portanto, as contagens de plântulas normais somente foram realizadas aos 8 dias, o que prolongou o período para a condução do teste. Além disso, houve desuniformidade no desenvolvimento das plântulas. Delouche (1976) cita que o regime de temperatura e o número de dias em que as sementes ficam expostas, após serem submetidas ao período de frio, também são fatores de interferência nos resultados.

De maneira geral, para todos os testes realizados e em todos os cultivares, os coeficientes de variação obtidos foram relativamente baixos e aceitáveis para testes conduzidos em laboratório.

Para o cultivar AG 122, os resultados obtidos nas determinaçōes do grau de umidade, germinação padrão, envelhecimento acelerado, emergência das plântulas em campo, teste de frio utilizando-se "terra" em caixas empilhadas , teste de frio utilizando-se "terra" em caixas dispostas lado a lado, teste de frio em bandejas utilizando-se apenas "terra" como substrato e teste de frio utilizando-se folhas de papel toalha e "terra" como substrato, encontram-se nas tabelas 6 e 7, para a primeira e segunda épocas respectivamente.

$\mathrm{Na}$ tabela 6, observa-se que todos os testes, inclusive o de germinação padrão, classificaram os lotes de maneira semelhante, apontando os lotes B e D como os de desempenho inferior. Nos testes de germinação padrão, 

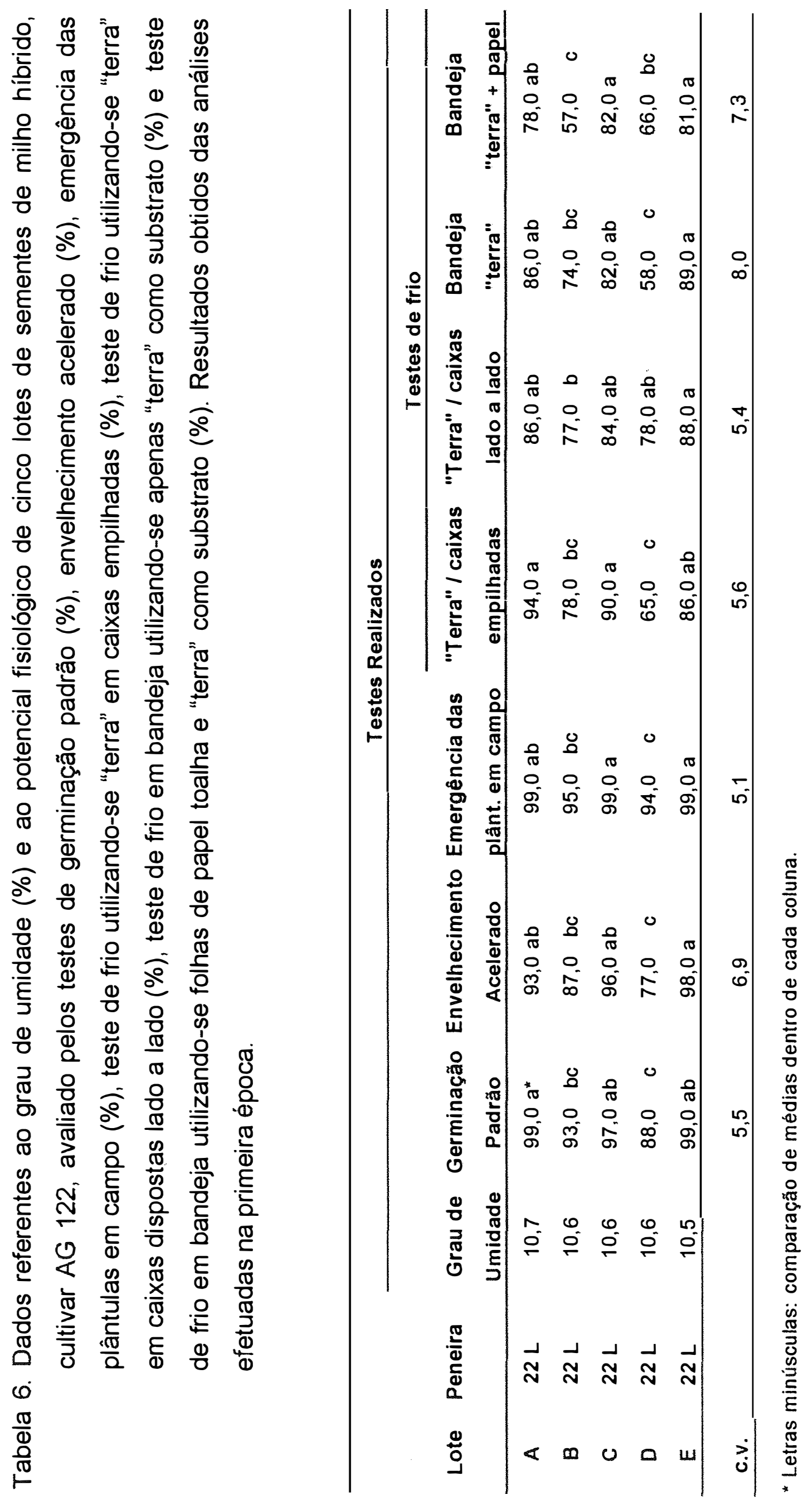
envelhecimento acelerado, teste de frio em caixas empilhadas e teste de frio em bandejas com "terra", apesar de não haver diferença significativa entre os lotes $B$ e $D$, foi ainda verificada tendência para caracterizar o lote $D$ como $\circ$ de potencial fisiológico menos elevado. Como as médias obtidas para o lote $\mathrm{D}$ foram as numericamente mais baixas, este foi identificado como o desempenho inferior embora, em termos práticos, as sementes possam ser consideradas de boa qualidade. Porém, o lote $B$ também mostrou deficiências, reveladas principalmente quando o procedimento adotado para a condução do teste de frio envolveu o uso de bandejas com "terra" + papel.

Em função das condições favoráveis de ambiente e também do alto potencial fisiológico das sementes, todos os lotes apresentaram alta porcentagem de emergência das plântulas em campo (superior a 94\%); de toda forma, houve diferença significativa e, novamente, os lotes B e D apresentaramse com desempenho inferior aos lotes A, C e E. Tais resultados foram compatíveis com os resultados obtidos nos testes realizados no laboratório, indicando que, em geral, todos os procedimentos permitiram identificar lotes com desempenho inferior. O fato do teste de frio em bandeja com "terra" ter apresentado o maior coeficiente de variação, não interferiu na eficiência do teste em distinguir lotes com diferentes níveis de vigor.

Nas análises efetuadas na segunda época (tabela 7), verifica-se que o teste de germinação padrão, não foi eficiente em detectar diferenças no potencial fisiológico dos lotes. A limitação do teste de germinação padrão em detectar diferenças no desempenho de lotes com alta capacidade de germinação, é amplamente documentada na literatura. Os resultados obtidos nos demais procedimentos, foram consistentes com os resultados da primeira época, detectando a inferioridade do desempenho dos lotes B e D. Considerando ainda esses dois lotes, também houve uma tendência de caracterizar o potencial fisiológico mais baixo para o lote $D$, não detectada pela análise estatística, quando foram comparados os lotes B e D; essa tendência somente não foi observada no teste de frio em bandeja com "terra", onde as 


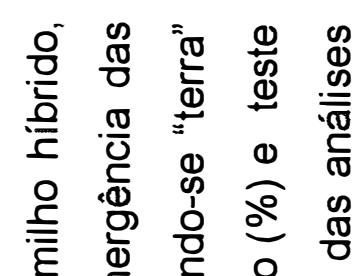

ป

® 仓

๕ั

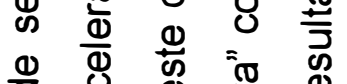

Ð ర

离 旁

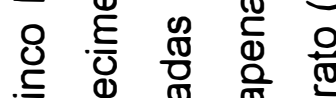

产

ญ ऐ ह

엉

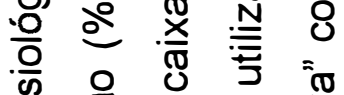

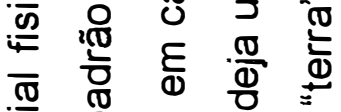

$\frac{\pi}{0}$ 造

㐫 㣽

으 क

(1)

ஓ

ญ

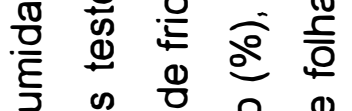

๑ 음 잉 웅

ป ญ

ธั่

인

๗

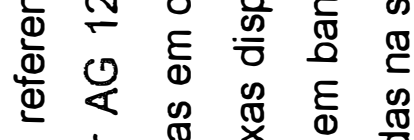

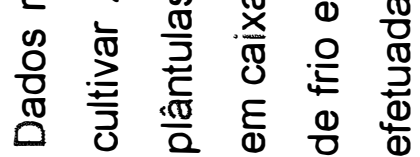

N

$\frac{\frac{\pi}{0}}{\frac{0}{\sigma}}$

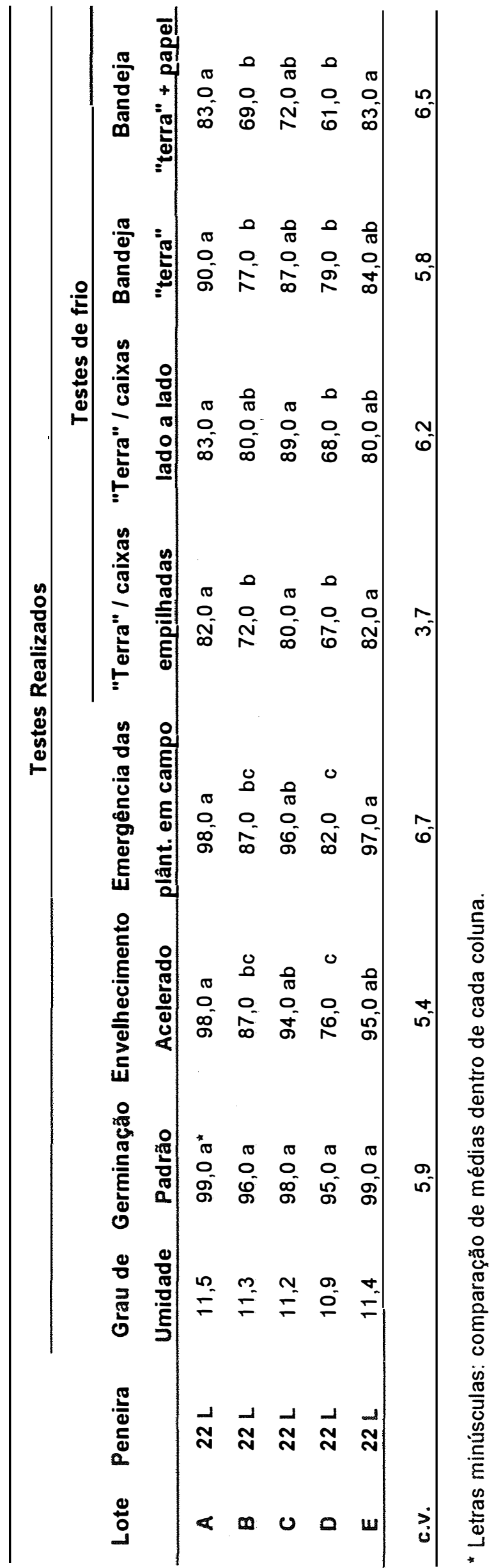


respostas dos dois lotes foram semelhantes. Tal fato também foi observado, na primeira época, com o método de "terra" em caixas dispostas lado a lado. Porém, isto não indica que os procedimentos não sejam sensiveis para avaliar o vigor, visto que tal diferença pôde ser detectada na primeira época para o método de bandeja com "terra" e na segunda época para o método de "terra" em caixa dispostas lado a lado. É importante ressaltar, que nesses procedimentos, esses dois lotes também foram de qualidade inferior aos demais.

Considerando os resultados da primeira e da segunda época, em conjunto, verifica-se que, de maneira geral, todos os procedimentos (com exceção do teste de germinação padrão para a segunda época) foram eficientes em avaliar a qualidade das sementes de milho, diferenciando, com segurança, lotes de mais alto dos de mais baixo potencial fisiológico. Segundo Marcos Filho (1999), existem certas dificuldades que, praticamente impossibilitam a identificação de lotes com nível médio de vigor. Dependendo do teste utilizado, esses lotes podem apresentar respostas semelhantes aos de vigor mais alto ou aos de potencial fisiológico mais baixo. Portanto, é necessário não confundir os lotes de alta dos de baixa qualidade, para não agravar as possibilidades de prejuízos ao produtor e ao consumidor.

Os quatro procedimentos do teste de frio, foram eficientes em identificar lotes com desempenho inferior. Porém, durante a condução desta pesquisa, tanto o método de "terra" em caixas empilhadas (no qual verificou-se o menor coeficiente de variação) como o método de "terra" em caixas dispostas lado a lado, apresentaram alguns problemas. Um deles, foi o peso relativamente elevado das caixas, as quais apresentavam aproximadamente $19 \mathrm{~kg}$ após o umedecimento do substrato, dificultando o manejo das mesmas. Outro ponto a ser destacado é que, após o ajuste da umidade, a água era totalmente absorvida pelo substrato; posteriormente, ao retirarem-se as caixas da câmara fria, verificou-se que algumas apresentavam-se com uma lâmina de água sobre parte da superfície do substrato, confirmando a hipótese de que, neste método, 
a distribuição de água não ocorre de maneira uniforme. Neste caso, as sementes não germinaram, e o teste foi instalado novamente para que se pudesse obter resultados confiáveis.

O ajuste da disponibilidade de água do substrato durante a condução do teste de frio inspira cuidados, pois, sabe-se que o excesso é prejudicial para a germinação elou emergência e também para o desenvolvimento das plântulas de milho (Fausey e McDonald, 1985). Svien e Isely (1955) e Heydecker (1969) destacaram que o excesso de água restringe a aeração, provocando reduções na germinação das sementes. Bruggink et al., (1991) verificaram que quando o substrato foi completamente saturado com água, todas as sementes morreram.

Para o cultivar AG 3010, os resultados obtidos nos diferentes testes, encontram-se nas tabelas 8 e 9 , para a primeira e segunda épocas respectivamente.

$\mathrm{Na}$ primeira época (tabela 8), observa-se que todos os testes de vigor identificaram o melhor desempenho dos lotes $C$ e $D$, não havendo diferenças significativas quanto à germinação. Para os demais lotes, notou-se que, no conjunto dos testes de vigor, os lotes $A, B$ e $E$ mostraram potencial fisiológico inferior, sendo o desempenho do lote $B$ confirmado no teste de emergência das plântulas em campo.

Durante as avaliações realizadas no teste de germinação padrão, verificou-se que algumas plântulas do lote $E$, apresentavam desenvolvimento de uma coloração marrom na região do mesocótilo e nas raízes. Posteriormente, essas plântulas foram submetidas ao método da "câmara úmida" (método para detecção de patógenos), sendo constatado o crescimento do fungo Fusarium moniliforme. Esses dados concordam com Ullstrup, (1977), onde lesões de coloração marrom nas raízes e na região do mesocótilo, são sintomas de plântulas infeccionadas. De toda a forma, a presença deste patógeno parece não ter exercido influência acentuada sobre a germinação e emergência das plântulas. Com resultado de $92 \%$ no teste de germinação padrão, o lote ainda pode ser considerado de boa qualidade se encaixando nos 

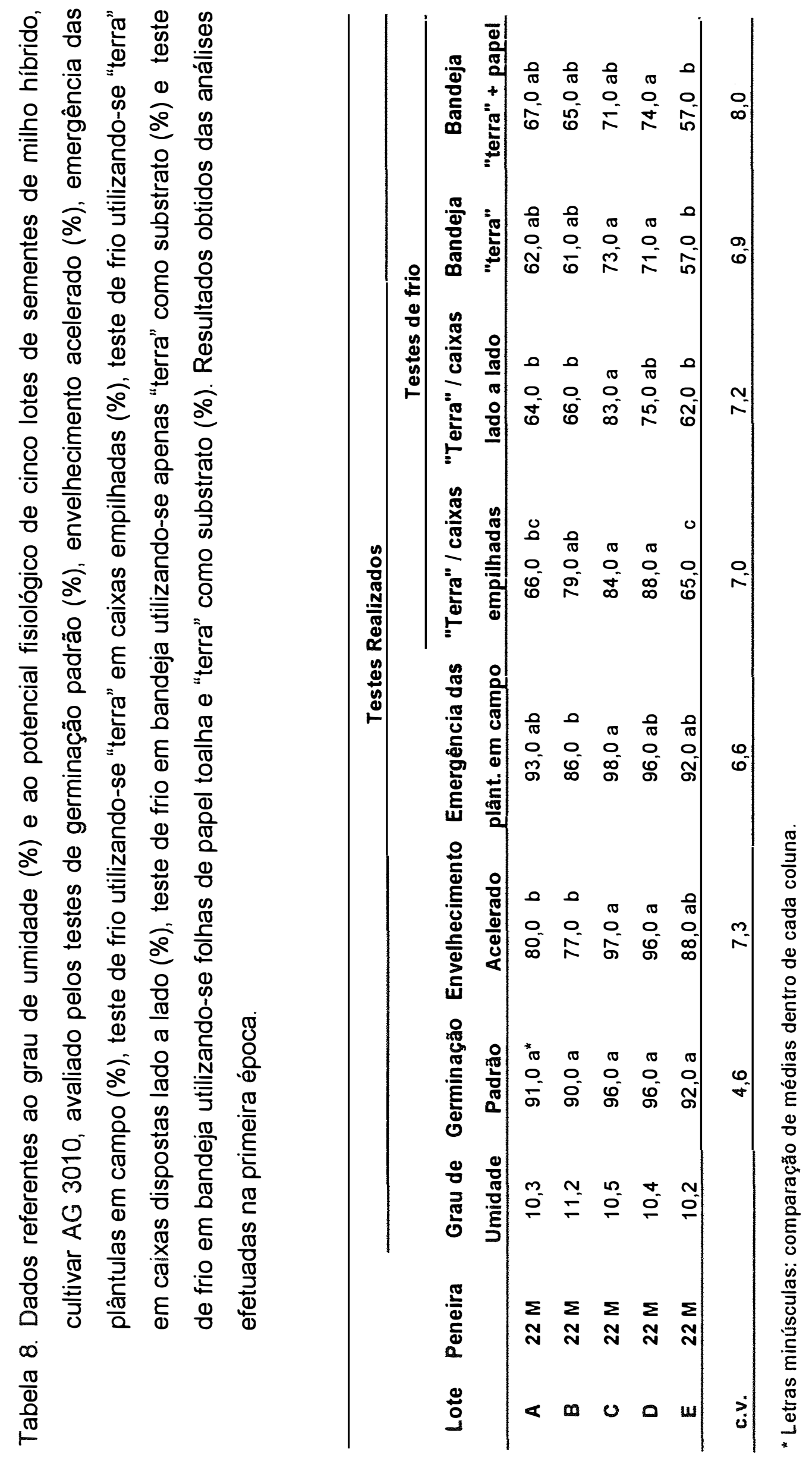
padrões mínimos exigidos para a comercialização. Pinto (1996) reportou que, os fungos Fusarium moniliforme e Cephalosporium acremonium, têm sido os de ocorrência mais freqüente e de mais altas porcentagens de detecção; porém, os mesmos não tem afetado a emergência das plântulas, quer em condições de semeadura a campo ou em casa de vegetação.

Nas quatro categorias do teste de frio, quando o lote $E$ foi comparado com os lotes A e B (também de desempenho inferior), apesar de não haver diferenças significativas (exceto para o teste de frio em caixas empilhadas entre os lote $E$ e $B$ ) houve uma tendência de comportamento inferior para o lote $E$, sendo que este apresentou médias numericamente mais baixas que as médias verificadas para os demais lotes. No entanto, no teste de envelhecimento acelerado e no teste de emergência das plântulas em campo, este lote teve bom desempenho. Neste caso, vários fatores podem ter influenciado os resultados.

Conforme comentam Medina e Marcos Filho (1990) um lote de sementes pode ser vigoroso em um aspecto, mas não em outros quando submetidos a condições de estresse qualitativamente diferentes. Deve-se destacar, ainda, que, os resultados do teste de frio, podem ser influenciados por fatores como o grau de maturidade das sementes no momento da colheita (Rush e Neal, 1951), danos causados pelas condições de armazenamento das sementes (Goodseel et al., 1955), danos causados por secagem excessiva (Loeffler et al., 1985; Martin et al., 1988), grau de umidade das sementes (Cal e Obendorf, 1972), injúrias no pericarpo (Tatum, 1954) e tratamento de sementes (Meulen e Henke, 1948; Hoppe 1956). Dependendo da causa determinante da baixa qualidade das sementes, a resposta poderá ser mais ou menos drástica, dificultando a interpretação dos resultados (Marcos Filho et al, 1987).

Esses dados enfatizam a importância de se utilizar mais de um teste para a avaliação do potencial fisiológico das sementes. De acordo com Marcos Filho (1999), o uso de apenas um teste pode gerar informações incompletas. Por exemplo, no caso da presente pesquisa, se fossem considerados apenas os 
resultados obtidos no teste de frio, o lote E poderia ser classificado como o lote de pior qualidade; ou então, poderia ser descartado, se fosse o caso de um programa de controle de qualidade de uma empresa. Por outro lado, se fossem considerados apenas os testes de envelhecimento acelerado, germinação padrão e emergência das plântulas em campo, onde o lote $E$ apresentou bom desempenho, sua deficiência em germinar e emergir em solo úmido e frio, não seria detectada; neste caso, se o lote fosse utilizado em condições desfavoráveis de campo (semelhantes as condições impostas pelo teste de frio), o prejuízo poderia ser significativo, em função da baixa porcentagem de emergência das plântulas.

Grabe (1976) destacou que a utilização de apenas um teste, não é suficiente para avaliar todos os aspectos do vigor, tendo sugerido combinação de resultados de vários testes, para a composição de um programa completo de avaliação da qualidade das sementes. Observações similares foram feitas por Hampton e Coolbear (1990), segundo as quais um único teste de vigor, não seria eficiente em avaliar todas as interações das sementes com as condições de ambiente durante a semeadura e, também, após a colheita.

Com relação aos procedimentos do teste de frio, a classificação dos lotes foi considerada mais consistente nos métodos de "terra" em caixas dispostas lado a lado, bandejas com "terra" e bandejas com "terra" + papel, os quais acusaram desempenho inferior para os lotes $A, B$ e $E$, não revelando diferenças estatísticas entre eles. Porém, no teste de frio em caixas empilhadas, o lote $B$ mostrou-se significativamente superior ao lote $E$ e também foi numericamente superior ao lote $A$, não havendo diferença significativa neste último caso. No entanto, ao relacionar os resultados com o teste de emergência das plântulas em campo, verifica-se desempenho inferior para o lote B. Alguns trabalhos de pesquisa mostram que condições mais estressantes no teste de frio, tornam o procedimento mais eficiente em separar lotes de sementes de milho com diferentes níveis de potencial fisiológico (Molina et al., 1987; Medina e Marcos Filho, 1990; Bruggink et al., 1991). 
$\mathrm{Na}$ segunda época (tabela 9) verifica-se que a diferença no comportamento dos lotes, pôde ser detectada mesmo no teste de germinação padrão, onde o lote $C$ mostrou desempenho significativamente superior aos lotes $A$ e $B$. $O$ teste de envelhecimento acelerado revelou potencial fisiológico mais elevado para os lotes $C$ e $D$, sendo o lote $B$ significativamente inferior a esses dois lotes. Os lotes $A$ e $E$, embora não apresentasse diferença significativa, também mostrou diferenças quando comparados aos lotes $C$ e $D$.

Nas quatro categorias do teste de frio, verificou-se desempenho superior para o lote $\mathrm{C}$. Novamente $\mathrm{o}$ teste de frio em caixas empilhadas, não apresentou resultados consistentes com os dos outros procedimentos e, também com os resultados dos testes de germinação padrão, envelhecimento acelerado e emergência das plântulas em campo. $O$ teste de frio em caixas empilhadas não detectou diferenças entre os lotes $A, B, D$ e $E$, sendo que o lote $D$, apesar de não haver diferença significativa, mostrou média numericamente inferior à do lote $E$, o qual apresentou potencial fisiológico mais baixo nos demais procedimentos do teste de frio. No teste de frio em bandeja com "terra", o lote D também não apresentou diferença significativa quando comparado com o lote $E$, mas apresentou média superior, indicando potencial fisiológico mais elevado.

$\mathrm{Na}$ classificação geral de todos os testes, com exceção do teste de frio em caixas empilhadas, as médias obtidas para o lote $D$ somente foram superadas numericamente pelas referentes ao lote $\mathrm{C}$; esse desempenho foi confirmado no teste de emergência das plântulas em campo.

Comparando os resultados da primeira com os da segunda época, verifica-se, ainda, um declínio do vigor para o lote $D$, detectado principalmente pelos procedimentos do teste de frio. Entretanto, no teste de emergência das plântulas em campo, onde as condições de ambiente eram favoráveis, o lote $D$ apresentou bom desempenho, indicando também que a queda de vigor não foi tão acentuada.

No teste de frio em caixas dispostas lado a lado, teste de frio em bandeja com "terra" e em bandeja com "terra" + papel, os lotes A, B e E, foram em geral 


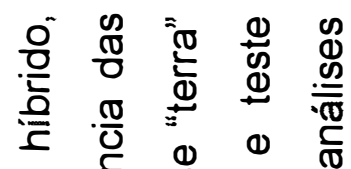

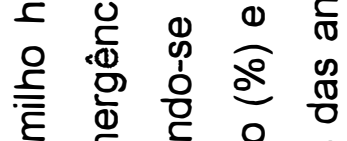

ब

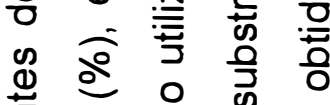

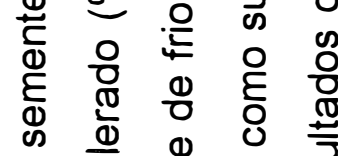

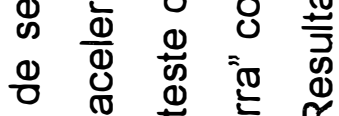

造

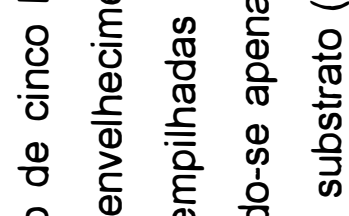

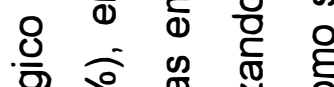

응

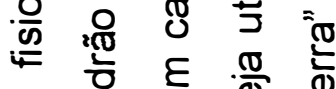

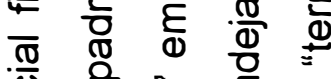

잉

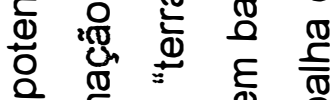

政

总

ลㅇำ

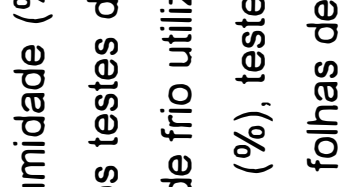

5

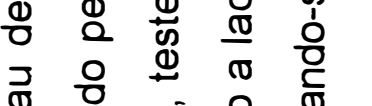

离

잉

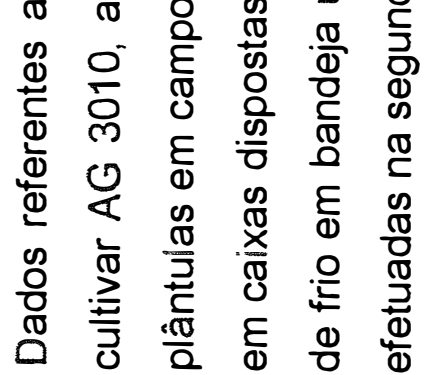

कं

$\frac{\pi}{0}$

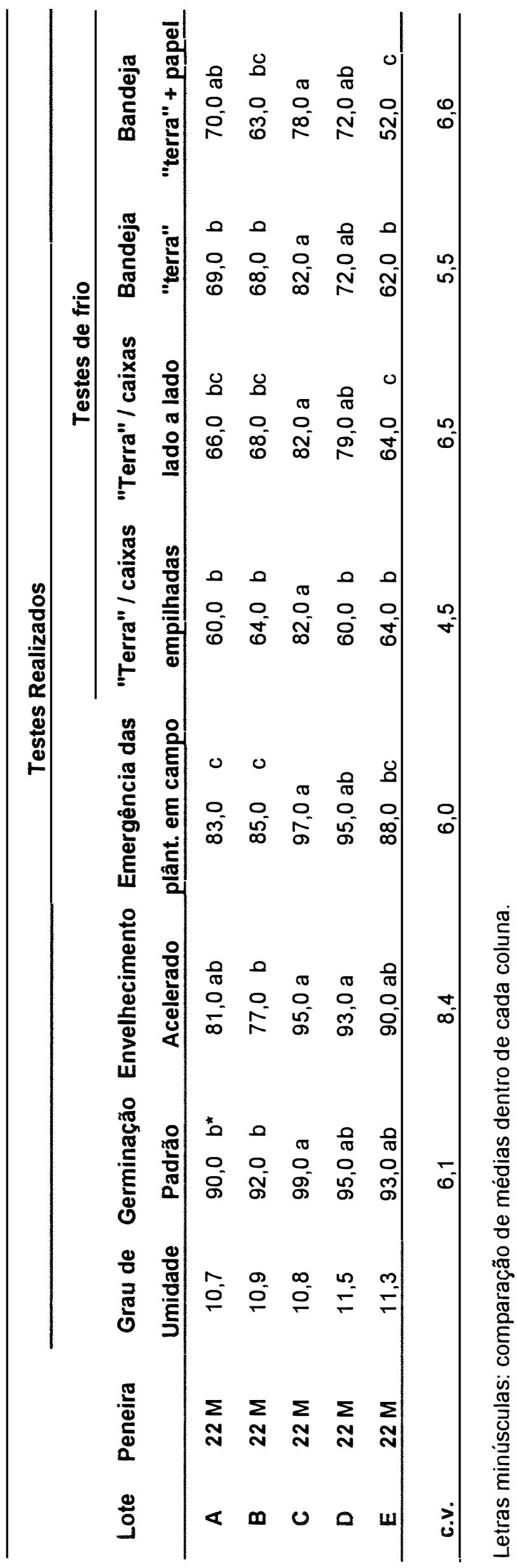


deficientes. O teste de emergência das plântulas em campo, confirmou a menor qualidade desses três lotes, especialmente para os lotes $A$ e $B$. O lote $A$ apresentava-se com potencial fisiológico mais elevado, na primeira época, o que pôde ser constatado pelo desempenho superior no teste de emergência das plântulas em campo. Na primeira época (tabela 8), os lotes A, B e E também mostraram qualidade inferior, principalmente $o$ lote $B$ que teve o pior desempenho em campo.

Considerando o conjunto de testes de vigor utilizados para a avaliação do potencial fisiológico do cultivar AG 3010, tanto na primeira como na segunda época, verifica-se que o teste de frio em caixas empilhadas não apresentou a mesma consistência de resultados observada para os demais testes, colocando em dúvida a qualidade do lote $B$ na primeira época e do lote $D$ na segunda época. Talvez a estratificação de temperatura do substrato, verificada durante as primeiras horas de resfriamento no sistema de caixas empilhadas, possa ter contribuído para a discrepância desses resultados em relação aos dos demais procedimentos do teste de frio, nos quais houve resfriamento mais rápido e uniforme do substrato. Burris (1990) cita que a injuria causada pelo resfriamento durante o período de embebição é um importante aspecto do teste de frio; assim, cuidados devem ser tomados para garantir o rápido resfriamento do substrato (para $10^{\circ} \mathrm{C}$ ), permitindo que a embebição ocorra uniformemente a baixas temperaturas.

As vantagens do teste de frio em bandeja encontradas na presente pesquisa, estão de acordo com as observações feitas por Burris (1990), onde o método, além de ser mais eficiente (menos tempo por teste), permite uma avaliação rápida e precisa das plântulas e, também, maior grau de controle das condições ambientais.

Os resultados obtidos para o cultivar AG 5011, encontram-se nas tabelas 10 e 11, para a primeira e segunda épocas respectivamente.

Os dados referentes à primeira época (tabela 10), mostram diferenças acentuadas no potencial fisiológico dos cinco lotes avaliados. Todos os testes, 

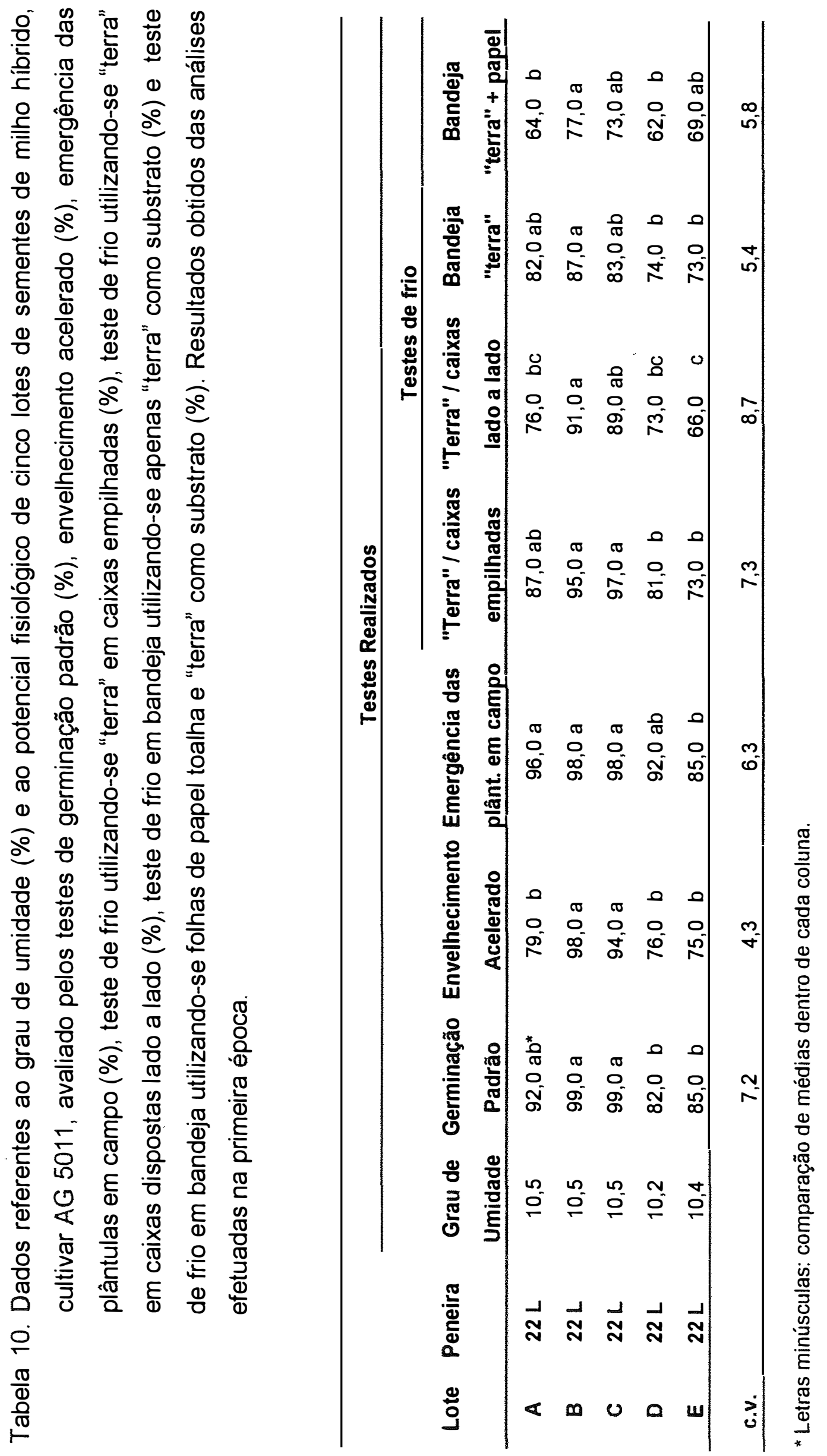
inclusive o de germinação padrão, classificaram os lotes A, D e E como os de pior desempenho. No teste de emergência das plântulas em campo, onde as condições de ambiente eram favoráveis, apenas o lote $E$ teve desempenho nitidamente inferior aos demais. Apesar de não haver diferença significativa entre os lotes $\mathrm{B}$ e $\mathrm{C}$, os testes de envelhecimento acelerado, de frio com "terra" em caixas dispostas lado a lado, os conduzidos em bandeja com "terra" e bandeja com "terra" + papel, também detectaram tendência do lote C apresentar desempenho ligeiramente inferior ao observado para o lote B. Por outro lado, os testes de envelhecimento acelerado e de frio em bandeja com "terra", provocaram agrupamento das médias referentes aos lotes D e E, cuja qualidade inferior havia sido detectada no teste de germinação padrão.

Apesar de não haver diferença significativa, os testes de emergência das plântulas em campo, teste de frio com "terra" em caixas empilhadas e em caixas dispostas lado a lado, detectaram diferenças entre os lote $D$ e $E$, sendo que este último apresentou qualidade inferior; porém esses mesmos testes não acusaram o declínio de vigor do lote $C$ (com exceção do teste de frio com "terra" em caixas dispostas lado a lado). O teste de frio em bandeja com "terra" + papel, ao contrário dos três testes citados, classificou o lote $D$ como menos vigoroso.

Comparando os quatro procedimentos do teste de frio, verifica-se, que de maneira geral, todos classificaram os cinco lotes de maneira semelhante, destacando-se maior eficiência para o teste de frio em bandeja com "terra" e em bandeja com "terra" + papel, em detectar diferenças no potencial fisiológico dos lotes B e C. Esses lotes apresentaram alto potencial fisiológico e a mesma porcentagem de germinação no teste de germinação padrão.

Segundo Delouche e Baskin (1973) a perda da capacidade germinativa, é o último evento que ocorre no processo de deterioração das sementes. Assim, lotes de sementes que possuem germinação compativel com os padrões para comercialização e que apresentam qualidade semelhante no teste de germinação padrão, requerem uma diferenciação mais sensivel no que diz 
respeito ao potencial de desempenho. Portanto, é nessas condições que os testes de vigor devem ser utilizados (Hampton e Coolbear, 1990). De maneira geral, para todos os cultivares avaliados, praticamente todos os lotes possuíam germinação compativel com os padrões para comercialização de sementes de milho.

Marcos Filho (1999) destaca que os testes de vigor foram desenvolvidos para proporcionar informações adicionais ao teste de germinação padrão e não para substituí-lo. Segundo AOSA (1983) o teste de germinação padrão é importante para a avaliação da qualidade das sementes, visto que possui metodologia padronizada (permitindo a reprodutibilidade dos resultados dentro e entre laboratórios), fornece informações sobre o potencial de um lote de sementes para germinar em condições ótimas de ambiente e também serve como base para a comercialização, fiscalização e processos de certificação de sementes.

Com relação aos dados obtidos na segunda época (tabela 11), verificase que a classificação dos lotes seguiu a mesma tendência observada na época anterior (tabela 10), principalmente para o teste de frio em bandeja com "terra". Diferenças mais acentuadas foram observadas para o teste de emergência das plântulas em campo, onde o lote A e D tiveram pior desempenho em relação ao verificado na primeira época.

$\mathrm{Na}$ segunda época, o teste de frio com "terra" em caixas empilhadas, detectou diferenças de vigor entre os lotes $\mathrm{B}$ e C; o mesmo não foi observado para o teste de frio em bandeja com "terra" + papel e teste de envelhecimento acelerado, onde as respostas desses dois lotes foram semelhantes. Vale lembrar que, na primeira época, essa tendência foi detectada pelos referidos testes. Talvez a diferença entre os lotes $B$ e $C$, não tenha sido detectada no teste de emergência das plântulas em campo, porque a queda de vigor do lote C não foi tão acentuada e, também, porque as condições de ambiente durante a condução do teste eram favoráveis, o que acabou permitindo um bom desempenho do lote $C$ no campo. Já no teste de frio em caixas dispostas lado a 


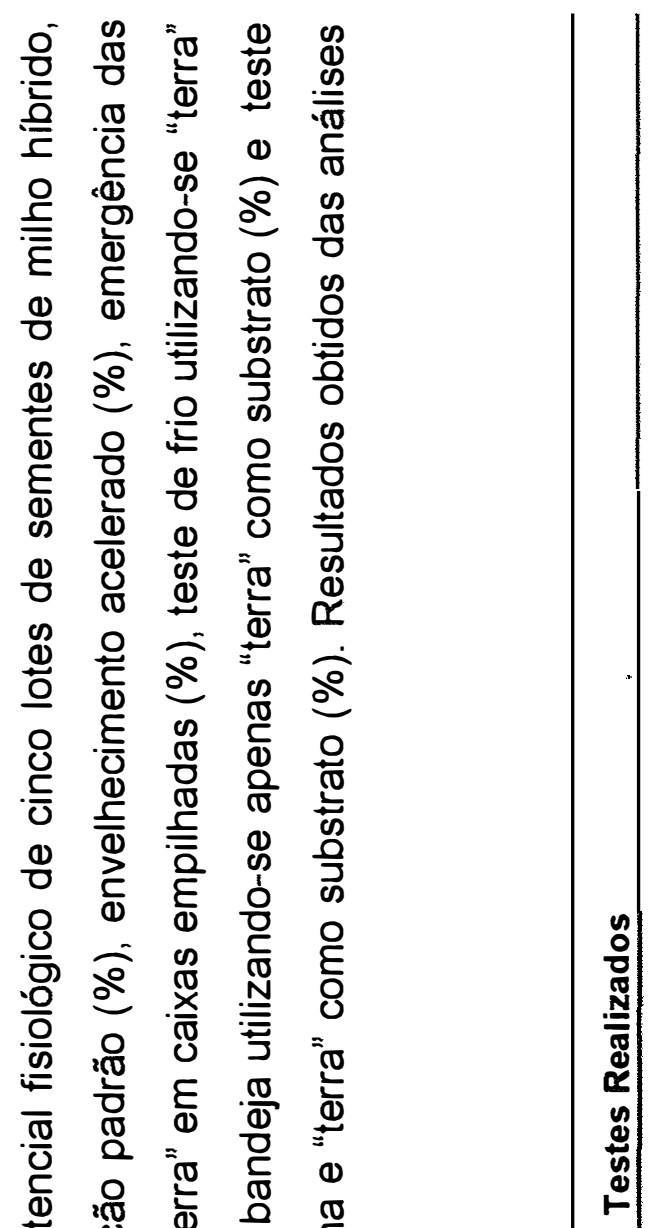

|

¿

○

(1)

ঐ

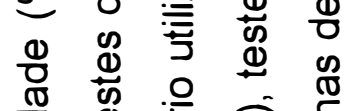

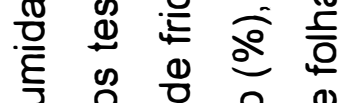

๑

उ

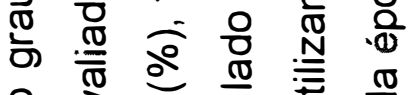

8 元 0 i

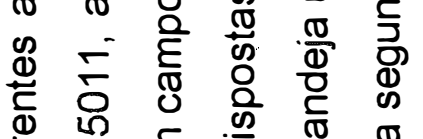

के

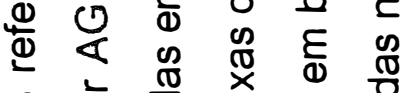

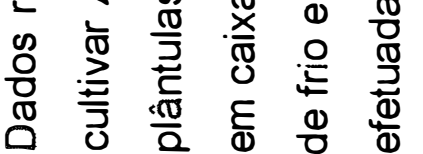

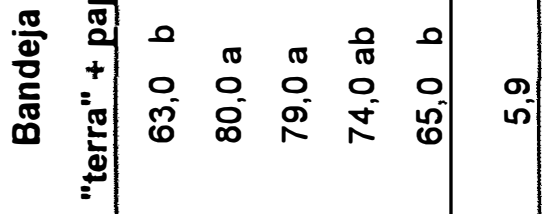

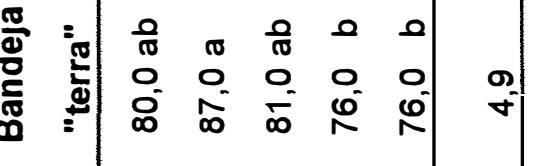

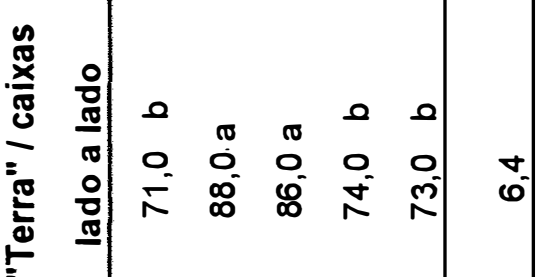

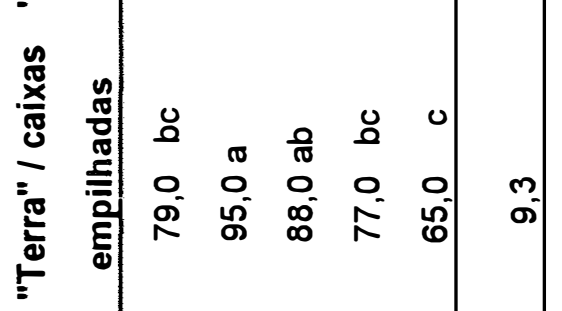

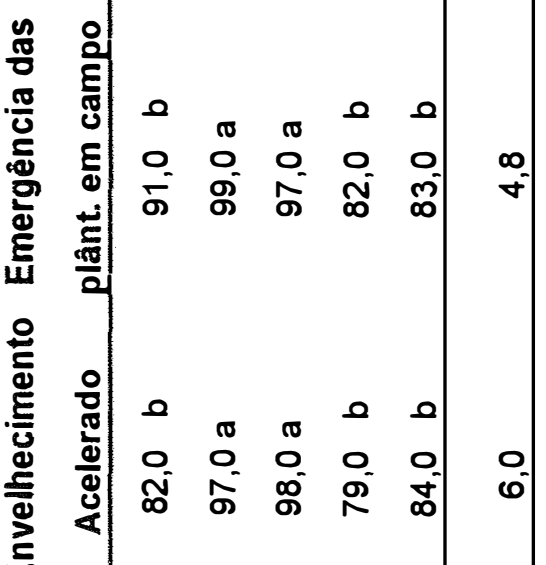

듬

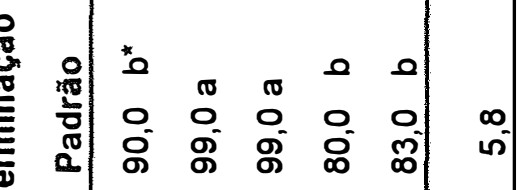

$\frac{\pi}{0}$

$\frac{0}{0}$

은 
lado, que detectou diferenças entre os lotes D e E na primeira época, houve um agrupamento de médias na segunda época.

Considerando todos os testes realizados para a avaliação do potencial fisiológico do cultivar AG 5011, tanto na primeira como na segunda época, o teste de envelhecimento acelerado e o procedimento do teste de frio em bandejas utilizando-se apenas "terra" como substrato, foram os mais consistentes, permitindo a reprodutibilidade dos resultados e se relacionando com o teste de emergência das plântulas em campo. Entre os procedimentos do teste de frio, foi o que apresentou menor coeficiente de variação, em ambas as épocas. Burris e Navratil (1979) também observaram relações dos resultados do teste de frio, obtidos pelo método da bandeja, com os de emergência das plântulas em campo. Os autores verificaram que o menor coeficiente de variação $(1,99 \%)$ foi obtido com o método da bandeja, que utiliza folhas de papel Kimpak + $500 \mathrm{~g}$ de "terra" como substrato.

A reprodutibilidade dos resultados é o principal requisito desejado para um teste destinado à avaliação da qualidade das sementes, para permitir a comparação consistente dos resultados (AOSA, 1983; Hampton e TeKrony, 1995). Porém, características como relação com a emergência das plântulas em campo sob certas condições, rapidez, objetividade, simplicidade de execução e viabilidade econômica, são também de fundamental importância para que um teste de vigor possa ser utilizado rotineiramente em um programa de controle de qualidade. Delouche (1976) cita que a padronização da metodologia e a da interpretação dos resultados, também são aspectos fundamentais.

Para o cultivar AG 6018, os resultados obtidos encontram-se nas tabelas 12 e 13, para a primeira e segunda épocas, respectivamente.

$\mathrm{Na}$ primeira época (tabela 12 ), observa-se que o lote $\mathrm{B}$ revelou desempenho inferior quando comparado aos demais lotes analisados, em todos os testes de vigor e também no teste de germinação padrão; esse comportamento foi confirmado no teste de emergência das plântulas em campo. 


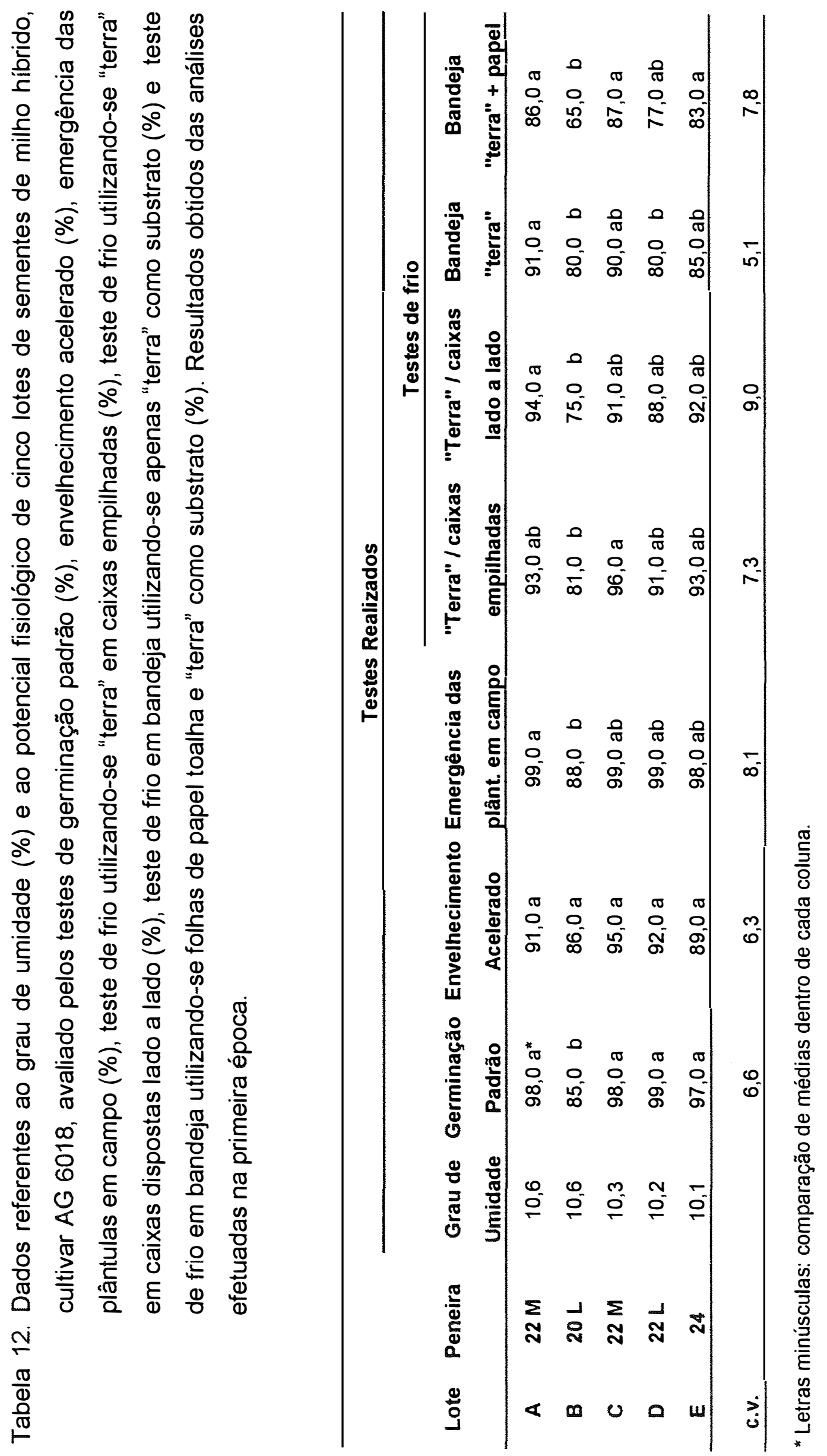


Com relação aos lotes $A, C, D$ e $E$, verifica-se que não diferiram significativamente em todos os testes (com exceção do teste de frio em bandeja com "terra"), sendo que todos apresentaram alto potencial fisiológico. Apenas o lote $D$, no teste de frio em bandeja com "terra", foi significativamente inferior ao lote $A$.

De toda forma, nas quatro categorias do teste de frio, apesar de não haver diferença significativa entre os lotes $D$ e $E$, houve tendência para o lote $D$ apresentar potencial fisiológico mais baixo. Os testes de frio em bandeja com "terra" e em bandeja com "terra" + papel, foram mais eficientes em revelar esta tendência. Tal fato não foi verificado na segunda época (tabela 13) onde o teste de envelhecimento acelerado e os quatro procedimentos do teste de frio, mostraram uma tendência de desempenho inferior para o lote $E$. No intervalo de tempo entre a primeira e segunda época, o lote E pode ter apresentado queda de vigor mais acentuada que o lote $\mathrm{D}$. O importante a ressaltar, é que todos os testes detectaram essa mudança de comportamento entre os dois lotes. No teste de emergência das plântulas em campo, considerando a primeira e segunda épocas, verifica-se que o comportamento entre os lotes $D$ e $E$ foi semelhante e que ambos tiveram bom desempenho; talvez isso possa ser explicado pelas condições favoráveis de ambiente, que permitiram rápida germinação e desenvolvimento das plântulas. Tal fato, também foi observado anteriormente para os outros cultivares analisados. Waes (1995) destacou que lotes menos vigorosos, podem apresentar desempenho satisfatório em campo, quando as condições climáticas são favoráveis após a semeadura.

Verifica-se que, de maneira geral, o cultivar AG 6018 mostrou desempenho superior nas quatro categorias do teste de frio, quando comparado com os outros três cultivares avaliados neste experimento. Pinnel (1949) verificou que a habilidade das sementes em germinar sob condições de baixa temperatura ambiente e alta umidade do solo, também está relacionada com o genótipo. O autor verificou que o melhor desempenho nestas condições, foi obtida por híbridos duplos, seguidos pelos híbridos simples e linhagens. 
Considerando os dados obtidos na primeira época para o cultivar AG 6018 , verifica-se que em todos os testes, a classificação obtida para os cinco lotes foi semelhante; porém, observa-se maior eficiência dos testes de frio em bandeja com "terra" e em bandeja com "terra" + papel, em detectar a propensão de potencial fisiológico mais baixo para o lote $D$, quando este foi comparado com o lote E. O teste de frio em bandeja com "terra" foi o que apresentou o menor coeficiente de variação, tanto na primeira como na segunda época.

$\mathrm{Na}$ segunda época (tabela 13) verifica-se, novamente, que o lote $\mathrm{B}$, teve o pior desempenho nos testes de germinação padrão, envelhecimento acelerado, emergência das plântulas em campo, teste de frio em caixas dispostas lado a lado e em bandeja com "terra" + papel. O teste em caixas empilhadas, classificou o lote $E$ como sendo o de qualidade mais baixa. Neste caso, o lote B teve um comportamento semelhante aos dos lotes mais vigorosos $(A$ e $C)$.

No teste em bandejas utilizando-se apenas "terra" como substrato, o lote E também apresentou potencial fisiológico mais baixo; no entanto, o lote $B$ teve comportamento semelhante ao lote $E$, sendo que ambos foram considerados de qualidade inferior. $A$ deficiência de desempenho do lote $B$, foi confirmada pelo teste de emergência das plântulas em campo.

Nos procedimentos utilizando "terra" em caixas dispostas lado a lado e em bandeja com "terra" + papel, o lote B mostrou desempenho inferior, sendo que $o$ lote $E$ superou apenas $o$ lote $B$. Considerando os quatro procedimentos do teste de frio, verifica-se que apenas o teste de frio em caixas empilhadas não foi eficiente em detectar a inferioridade do lote $B$.

Os lotes $\mathrm{A}$ e $\mathrm{C}$, considerados lotes com potencial fisiológico mais elevado, não apresentaram diferença significativa nos testes de germinação padrão, envelhecimento acelerado e nas quatro categorias do teste de frio. Porém, no teste de emergência das plântulas em campo, o lote $C$ foi significativamente inferior ao lote $A$ embora, na prática, ambos possam ser considerados de boa qualidade. 


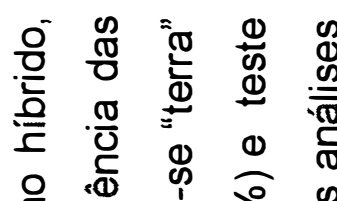

을

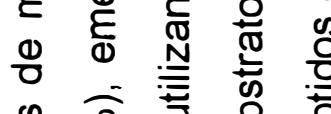

\& ๙

蛋

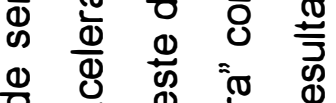

ర

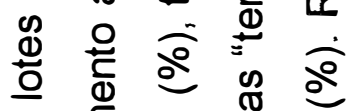

○ है ণ

ป 仓

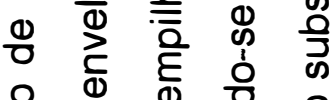

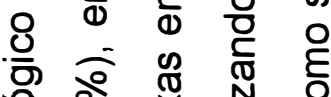

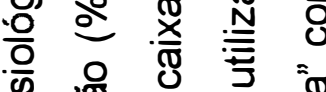

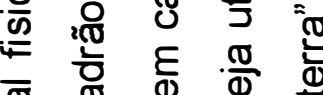

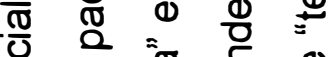

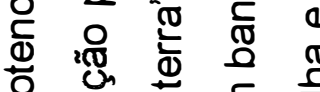

¿ đ্்

이 है 仓

๑)

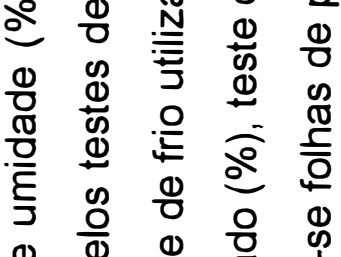

ब

진

ช

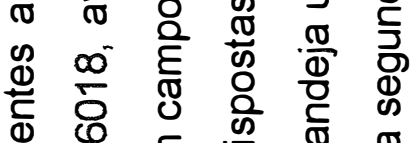

ब

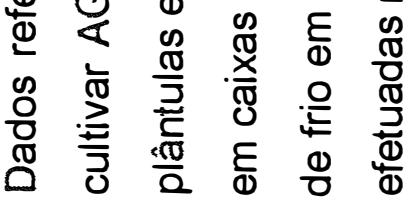

m

$\frac{\pi}{\frac{0}{0}}$

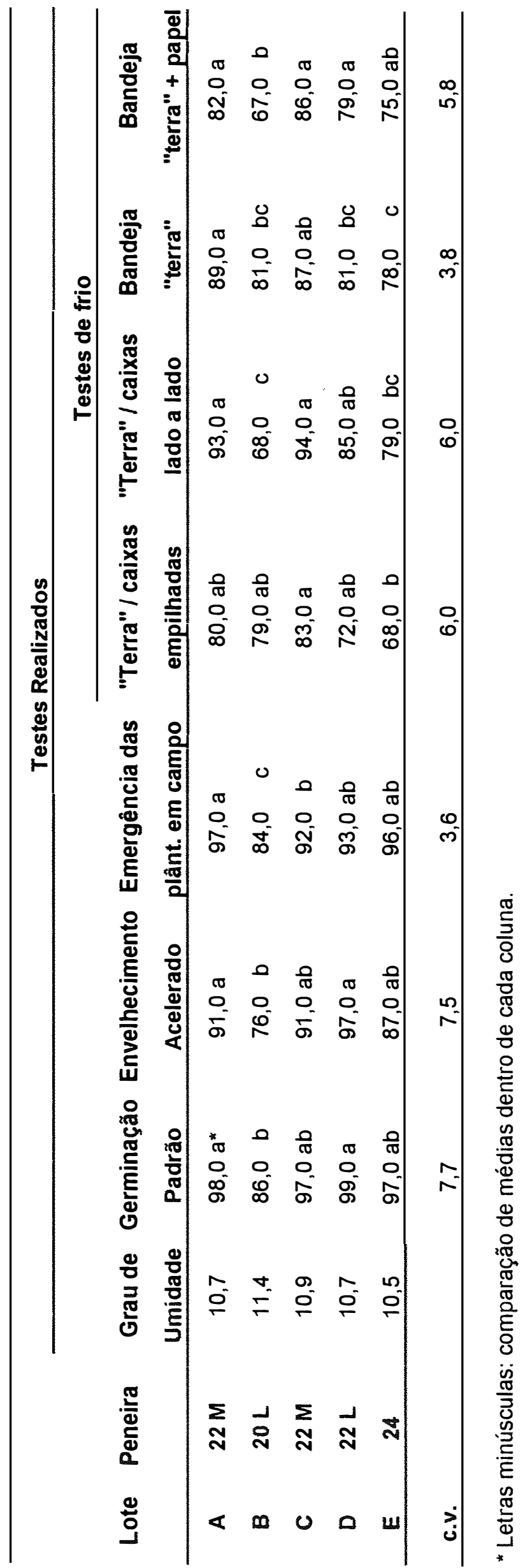


Analisando os lotes $C$ e $D$, os quais apresentaram altas porcentagens de germinação, verificou-se que, nas quatro categorias do teste de frio, houve tendência de menor potencial fisiológico para o lote D. Já no teste de envelhecimento acelerado, constatou-se tendência de potencial fisiológico mais baixo para $\circ$ lote $C$. Neste caso, o lote $D$, parece ter sido mais sensível as condições de estresse impostas pelo teste de frio do que pelo teste de envelhecimento acelerado. No entanto, ao analisar os dados da emergência das plântulas em campo verifica-se comportamento semelhante desses lotes.

Com relação aos dados obtidos na segunda época, verifica-se a mesma tendência na classificação dos lotes, especialmente para o lote $B$ que teve o pior desempenho. Deve-se destacar que, apenas no teste de frio em caixas empilhadas o lote $B$ teve comportamento semelhante aos dos lotes de potencial fisiológico mais alto ( $A$ e $C$ ), não sendo considerado como o lote de vigor mais baixo. No entanto, verifica-se que esta metodologia não foi eficiente na classificação dos lotes, visto que no teste de emergência das plântulas em campo, ficou caracterizado o pior desempenho para o lote B. 


\section{CONSIDERAÇÕES GERAIS}

De maneira geral, comparando os quatro procedimentos do teste de frio, verifica-se maior eficiência para os procedimentos de "terra" em caixas dispostas lado a lado, teste de frio em bandeja com "terra" e teste de frio em bandeja com "terra" + papel. O teste em caixas empilhadas, além de apresentar estratificação de temperatura do substrato durante as primeiras horas de resfriamento, revelou deficiências na classificação dos lotes, principalmente para os cultivares AG 3010 e AG 6018.

Apesar do teste de frio em caixas dispostas lado a lado, ter apresentado a mesma eficiência que os dois procedimentos do teste de frio em bandeja, em separar lotes com diferentes niveis de vigor, apresenta o inconveniente de ocupar mais espaço no interior da câmara fria e também da necessidade de resfriamento do substrato antes da instalação do teste. Para empresas e/ou instituições que avaliam grande quantidade de amostras e que adotam o teste de frio como teste de rotina para a avaliação do potencial fisiológico das sementes, esses fatores se constituiriam entraves para o setor de controle de qualidade.

Embora existam alguns trabalhos citando o controle da umidade relativa como uma desvantagem para o método da bandeja, neste experimento, o controle deste fator e, também, da temperatura do ambiente onde as sementes foram colocadas para germinar, foi importante para a padronização do teste $e$ para a obtenção de resultados mais consistentes. O ajuste desses dois parâmetros e, também, a utilização de camada menos espessa de "terra", promoveram um desenvolvimento mais rápido e uniforme das plântulas (podendo reduzir o número de dias necessários para a avaliação), além de possibilitarem a condução do teste em uma época do ano em que a temperatura ambiente geralmente é mais baixa.

O teste de frio em bandeja (utilizando-se apenas "terra" ou "terra" + papel como substrato), mostrou ser mais adequado para avaliação do potencial 
fisiológico das sementes de milho, pois, promove o resfriamento mais rápido e uniforme do substrato, além de apresentar simplicidade de execução, consistência nos resultados e relação com os resultados da emergência das plântulas em campo. Os testes foram eficientes tanto quando as diferenças entre lotes eram mais estreitas, como quando eram mais amplas. 


\section{CONCLUSÔES}

As análises dos dados e a interpretação dos resultados obtidos no presente trabalho permitiram as seguintes conclusões:

- O teste de frio em bandejas oferece maior facilidade para padronização do que o teste de frio utilizando-se "terra" em caixas, permitindo a obtenção de resultados mais consistentes, inclusive quanto à relação com emergência das plântulas em campo.

- O teste de frio em bandejas utilizando-se apenas "terra" $(2 \mathrm{~kg})$ ou "terra" $(1 \mathrm{~kg})+$ papel toalha (22 folhas), com umidade do substrato ajustada para $70 \%$ da sua capacidade de retenção de água, conduzido em ambiente controlado de temperatura, umidade relativa e luz, pode ser utilizado com segurança para a avaliação do potencial fisiológico das sementes de milho. 


\section{REFERÊNCIAS BIBLIOGRÁFICAS}

ASSOCIATION OF OFFICIAL SEED ANALYSTS (AOSA), ed. Seed vigor testing handbook. Contrib. $n^{\circ} 32$ to the Handbook on Seed Testing. $88 p$, 1983.

BARROS, A.S.R.; DIAS, M.C.L.L. Aferição de testes de vigor para sementes de milho (Zea mays L.). Informativo ABRATES, v.2, n.4, p. 10-22, 1992.

BARROS, A.S.R.; DIAS, M.C.L.L. Aferição de testes de vigor para sementes de milho (Zea mays L.). Segunda etapa:1994/95. Informativo ABRATES, v.6, n.2/3, p.24-40, 1996.

BASKIN, C.C.; DELOUCHE, J.C.; CABRERA, E.R. The influence of packaging material, seed moisture content and storage environment on seed storabilility and performance. Newsletter-of-the-Association-of-OfficialSeed-Analysts, v.61, n.2, p.15, 1987. /Resumo em CAB Abstracts on CDROM, $1987 /$.

BRASIL. Ministério da Agricultura e da Reforma Agrária. Regras para análise de sementes. Brasilia: SNDAVNDV/CLAV, 1992. 365p. 
BRUGGINK, H.; KRAAK, H.L.; BEKENDAM, J. Some factors affecting maize (Zea Mays L.) cold tests results. Seed Science and Technology, v.19, n.1, p.15-23, 1991.

BURRIS, J.S.; NAVRATIL, R.J. Relationship between laboratory cold-test methods and field emergence in maize imbreds. Agronomy Journal, v.71, n.6, p.985-988, 1979.

BURRIS, J.S. Recommended cold test procedure. Journal of Seed Technology, v.14, n.2, p.182-194, 1990.

BYRD, H.W.; DELOUCHE, J.C. Deterioration of soybean seed in storage. Proceeding of the Association of Official Seed Analysts, v.61, p.41-57, 1971.

BYRUM, J.R.; COPELAND, L.O . Variability in vigour testing of maize (Zea Mays L.). Seed Science and Technology, v.23, n.2, p.543-549.1995.

CAL, J.P.; OBENDORF, R.L. Imbibitional chilling injury in Zea mays L. altered by initial kernel moisture and maternal parent. Crop Science, v.12, p.369373, May/June, 1972.

CHRISTIANSEN, M.N. Induction and prevention of chilling injury to radicle tips of imbibing cottonseed. Plant Physiology, v.43, p.743-746, 1968. 
CÍCERO, S.M.; VIEIRA, R.D. Teste de frio. In: VIEIRA, R.D.; CARVALHO, N.M. Testes de vigor em sementes. Jaboticabal: FUNEP, 1994. p.151-164.

CROSIER, W.F. Fungi envolved and methods of conducting cold tests. Proceedings of the Association of Official Seed Analysts, v.47, p.185190, 1957.

DELOUCHE, J.C. Standardization of vigor tests. Journal of Seed Technology, vol.1, n.2, p.75-85, 1976.

DELOUCHE, J.C.; BASKIN, C.C. Accelerated aging techniques of predicting the relative storability of seed lots. Seed Science \& Technology, vol.1, p.427452, 1973.

DESAl, M.V.; REDDY, C.S. A uniform seed corn cold test. Phytopathology, v.48, p.386-387, 1958.

DIAS, M.C.L.L.; BARROS, A.S.R. Avaliação da qualidade de sementes de milho. Londrina: IAPAR, 1995. 43p. (IAPAR. Circular, 88).

FAUSEY, N.R.; MCDONALD JUNIOR, M.B. Emergence of inbred and hybrid corn following flooding. Agronomy Journal, vol.77, p.51-56, Jan./Feb., 1985.

FIALA, F. Cold test. In: PERRY, D.A. (Ed.) Handbook of vigour test methods. Zürick: ISTA, 1981. p. 28-36. 
FIALA, F. Report of the Vigour Test Committee 1983-1986. Seed Science and Technology, v.15, p.507-522, 1987.

GOODSELL, S.F.; HUEY, G.; ROYCE, R. The effect of moisture and temperature during storage on cold test reaction of Zea mays seed stored in air, carbon dioxide, or nitrogen. Agronomy Journal, vol.47, p.61-64, 1955.

GRABE, D.F. Measurement of seed vigor. Journal of Seed Technology, v.1, n.2, p.18-32, 1976.

HAMPTON, J.G.; COOLBEAR, P. Potential versus actual seed performance can vigour testing provide an answer? Seed Science \& Technology, v.18, n.2, p.215-228, 1990.

HAMPTON, J.G.; TEKRONY, D.M. Handbook of vigour test methods. 3.ed. Zurich: International Seed Testing Association, 1995. 117p.

HASKELL, G. Effect of low temperatures on the germination of inbred lines of sweet corn. Science, v.107, p.150, 1948.

HEYDECKER, W. The "vigour" of seeds - a review. Proceeding of the International Seed Testing Association, v.34, n.2, p.201-219, 1969.

HOOKS, J.A.; ZUBER, M.S. Effects of soil and soil moisture levels on cold test germination of corn. Agronomy Journal, v.55, p.453-455, 1963. 
HOPPE, P.E. A new technique for incubating seed corn in cold soil for disease tests. Phytopathology, v.41, p.747-751, 1951.

HOPPE, P.E. Correlation between corn germination in laboratory cold tests and stands in the field. Plant Disease Reporter, v.40, n.10, p.887-889, 1956.

KRZYZANOWSKI, F.C.; FRANÇA NETO, J.B.; HENNING, A.A. Relato dos testes de vigor disponiveis para grandes culturas. Informativo ABRATES, v. 1, n.2, p.15-50, 1991.

LOEFFLER, N.L.; MEIER, J.L.; BURRIS, J.S. Comparison of two cold test procedures for use in maize drying studies. Seed Science and Technology, v.13, n.3, p.653-658, 1985.

LOVATO, A.; CAGALLI, S. Sugar beet (Beta vulgaris L.) seed vigour compared inlaboratory and field tests. Seed Science and Technology, v.21, p.61-67, 1992.

LOVATO, A.; BALBONI, N. Seed vigour in maize (Zea Mays L.): two year laboratory and field test compared. Italian-Journal-of-Agrinimy, v.1, n.1, p.1-6, 1997. / Resumo em CAB Abstracts on CD-ROM, $1997 /$.

MARCOS FILHO, J.; CICERO, S.M.; SILVA, W.R. Avaliação da qualidade das sementes. Piracicaba: FEALQ, 1987. 230p. 
MARCOS FILHO, J. Testes de vigor: importância e utilização. In: KRZYZANOWSKI, F.C.; VIEIRA, R.D.; FRANÇA NETO, J.B. Vigor de Sementes: Conceitos e Testes. Londrina: ABRATES, 1999. p.1-1-1-21.

MARTIN, B.A.; SMITH, O.S.; O'NEIL, M. Relationships between laboratory germination tests and field emergence of maize inbreds. Crop Science, v. 28, p.801-805, 1988.

MEDINA, P. F.; MARCOS FILHO, J. Avaliação da qualidade fisiológica das sementes de milho (Zea mays L.). Anais da Escola Superior de Agricultura "Luiz de Queiroz", v.47, n.1, p. 47-70, 1990.

MEULEN, V.E.; HENKE, F. Cold testing of seed corn. Seed World, v.63, n.7, p.8-10, 1948.

MOLINA, J.C.; IRIGON, D.L.; ZONTA, E.P. Comparação entre metodologias de teste de frio na avaliação da qualidade fisiológica de sementes de milho (Zea mays L.). Revista Brasileira de Sementes, v.3, p.77-85, 1987.

NIJENSTEIN, J.H. Effects of some factors influencing cold test germination of maize. Seed Science and Technology, v.14, n.2, p.313-326, 1985.

NIJENSTEIN, J.H. Effects of soil moisture content and crop ratation on cold test germination of corn (Zea mays L.). Joumal of Seed Technology, v.12, n.1, p.99-106, 1988. 
PINNELL, E.L. Genetic and environmental factors affecting corn seed germination at low temperatures. Agronomy Journal, v.41, p.562-568, 1949.

PINTO, N.F.J.A. Tratamento fungicida de sementes de milho. In: SIMPÓSIO BRASILEIRO DE PATOLOGIA DE SEMENTES, 4., Gramado, 1996. Tratamento químico de sementes. Anais. Campinas: Fundação Cargill, 1996. p.52-57.

POLLOCK, B.M.; TOOLE, V.K. Imbibitional period as the critical temperature sensitive stage in germination of lima bean seeds. Plant Physiology, v.41, p.221-229, 1966.

RUSH, G.E.; NEAL, N.P. The effect of maturity and other factors on stands of corn at low temperatures. Agronomy Journal, v.43, p.112-116, 1951.

SVIEN, T.A.; ISELY, D. Factors affecting the germination of corn in the cold test. Proceedings of the Association of Official Seed Analysts, vol.45, p.8086, 1955.

TAO, K.J. Effects of soil water holding capacity on the cold test for soybeans. Crop Science, v.18, p.979-982, 1978.

TATUM, L.A. Seed permeability and "cold-test" reaction in Zea mays. Agronomy Journal, v.46, p.8-12, 1954. 
ULLSTRUP, A.J. Diseases of corn. In: Sprague, G.F. Corn and Corn Improvement. Madison, Wisconsin: American Society for Agronomy, 1977. p.391-500.

VIEIRA, R.D.; TEKRONY, D.M.; EGLI, D.B. Effect of drought stress on soybean seed germination and vigor. Joumal of Seed Technology, v.15, n.1, p.1221, 1991.

VON PINHO, E.V.R.; CAVARIANI, C.; ALEXANDRE, A.D.; MENTEN, J.O.M.; MORAES, M.H.D. Efeitos do tratamento fungicida sobre a qualidade sanitária e fisiológica de sementes de milho (Zea mays L.). Revista Brasileira de Sementes, v.17, n.1, p.23-28, 1995.

WAES, J.V. The use of a cold test to predict field emergence of maize in official variety trials in Belgium. Seed Science and Technology, v.23, n.1, p.211224.1995.

WATERS, L.JR.; BLANCHETTE, L.B. Prediction of sweet corn field emergence by conductivity and cold tests. Joumal of the American Society for Horticultural Science, v.108, n.5, p.778-781, 1983.

WOLTZ, J.M. Prospects for the standardization of the cold test for corn seed. Lexington, 1997. 104p. Dissertation (M. S.) - University of Kentucky. 
WOLTZ, J.M.; TEKRONY, D.M.; EGLI, D.B.; VINCELLI, P. Corn cold test germination as influenced by soil moisture, temperature, and pathogens. Seed Technology, vol.20, n.1, p.56-70, 1998.

WOODSTOCK, L.W.; POLLOCK, B.M. Physiological predetermination: imbibition, respiration, and growth of lima bean seeds. Science, v.150, p.1031-1032, 1965. 